\title{
SCRIPTA ISLANDICA
}

\author{
ISLÄNDSKA SÄLLSKAPETS \\ ÅRSBOK 72/2021
}

\author{
REDIGERAD AV \\ LASSE MÅRTENSSON OCH VETURLIĐI ÓSKARSSON
}

\author{
under medverkan av \\ Pernille Hermann (Århus) \\ Else Mundal (Bergen) \\ Guðrún Nordal (Reykjavík) \\ Heimir Pálsson (Uppsala) \\ Henrik Williams (Uppsala)
}

UPPSALA, SWEDEN 
Utgiven med stöd från Vetenskapsrådet

(C) 2021 respektive författare (CC BY)

DOI: 10.33063/diva-439399

Sättning: Ord och sats Marco Bianchi

Isländska sällskapet

Institutionen för nordiska språk vid Uppsala universitet

ISSN 0582-3234 (tryckt)

ISSN 2001-9416 (digitalt) 


\section{Innehåll}

Felix Lummer, Of Magical Beings and Where to Find Them: On the Concept of álfar in the translated riddarasogur $\ldots \ldots \ldots \ldots$ Frog, Preserving Blunders in Eddic Poems: Formula Variation in Numbered Inventories of Vafprúðnismál and Grímnismál . . . . 43

LASSE MÅRTENSSON, The Change menninir > mennurnir, mennirnir in Icelandic . . . . . . . . . . . . . . . . . . . . . . . . 93

MARTIN RINGMAR, Läsning för folket? Gunnlaugs saga ormstungu i skandinaviska nyöversättningar: Hur? För vem? Varför? . . . . . . 107

Mikael Males, Kan fornisländskans rúnar betyda 'bokstäver'? . . 127

\section{Recension}

Lasse MÅrtensson, Rec. av Karl G. Johansson och Elise Kleivane (red.). Speculum septentrionale. Konungs skuggsjá and the European Encyclopedia of the Middle Ages . . . . . . . . . . . . . 137

Författarna i denna årgång $\ldots \ldots \ldots \ldots \ldots \ldots \ldots \ldots \ldots$ 



\title{
Of Magical Beings and Where to Find Them On the Concept of álfar in the Translated riddarasogur
}

\author{
FELIX LUMMER
}

\section{Introduction}

The process of translation attempts to enable the understanding of foreign concepts and ideas, something which naturally involves the use of both words and concepts that are already extant in the receiving culture. This naturally involves linguistic problems, but more interestingly often results in the overlapping, alteration and merging of concepts, something that can have long-term consequences on language and cultural understanding. This article aims to explore how the Old Norse mythological concept of the álfar in the Nordic countries (especially Iceland due to its preserved manuscripts) may have been altered through the influence of the translation of Old French romances into Norwegian and Icelandic during the Middle Ages. As will be shown below, the mythological concept that lies behind the introduction and use of the female variant of álfar (sg. álfr) known as álfkonur (sg. álfkona) in Old Norse literature (and culture) appears to have been that of the Old French fée (pl.fées). Indeed, prior to the translation of foreign (especially Continental) works, some of which appear to have been initiated by the Norwegian King Hákon Hákonarson (1204-1263) in the early thirteenth century, the álfkona (and motifs associated with her) seem to have been mostly absent in Old Norse

Lummer, Felix. 2021. Of Magical Beings and Where to Find Them:

On the Concept of álfar in the Translated riddarasogur.

Scripta Islandica 72: 5-42.

(C) Felix Lummer (CC BY)

DOI: $10.33063 /$ diva-439400 
literature and folk belief (one minor exception is, for example, Fáfnismál st. 13). ${ }^{1}$

The present investigation will thus consider those instances in which Old Norse álfkonur appear in the corpus of the translated riddarasogur, exploring the concepts that lie behind them in the respective source material, and noting similarities as well as discrepancies in the said concepts. In so doing, various questions will be posed, such as: What caused the need to introduce the new concept of álfkonur when other supernatural female beings (nornir and dísir, for instance) already existed in Old Norse, especially if the various attributes of the Old French fées seem to have warranted a translation using either dís or norn? How much potential background was there for the development of the concept of the álfkona in local folklore and popular beliefs in the Nordic countries in the thirteenth and fourteenth centuries? Last but not least, the article will consider how far reaching the influence of translators and their attempts to adapt foreign material to fit local beliefs was and what influence it had on the nature of the translated stories. This last question is of particular interest as it appears that in most cases the respective Old Norse translators seem to have regularly transformed, altered and adapted their material to fit the worldviews of their new Nordic audiences, either on the basis of demands by the commissioner of the translation or because of their personal urge to do so (possibly simply in order to enable or further understanding by the designated audience or because they themselves misunderstood the original concepts).

It needs to be borne in mind that supernatural concepts, especially those of the fées and álfar, cannot be regarded as having been steady concepts. As will be demonstrated below, they changed over the course of various centuries and of course varied by area. The question of how such conceptual translations resonated in the receiving society at any given time thus naturally presents several problems. These evidently include various conundrums regarding how the sources were understood at the time of translation, the time span involved in the process of writing and translating, and the taxonomy of the supernatural concepts investigated. The sources and the concepts used in them pose similar difficulties, one being that the act of tracing developments in two different cultures over

\footnotetext{
${ }^{1}$ Unless otherwise stated, all information regarding Eddic poetry, such as the number of stanzas cited are taken from the two-volume edition titled Eddukvaæ $i$ by Jónas Kristjánsson and Vésteinn Ólason published in 2014.
} 
the course of at least two centuries on the basis of translated works can only use extant material which has been randomly preserved, meaning that the available evidence has been conserved by chance. In other words, while the picture one might reach on the basis of comparing the extant Old French and Old Norse literary corpora to examine the translation of fées to álfkonur may be tangible, it is bound to be somewhat speculative. It is also evident that the multi-facetted supernatural concepts involved seem to have been undergoing change between the late $12^{\text {th }}$ and $14^{\text {th }}$ centuries, in both France and in Scandinavia. Because of the difficulty in finding any term in modern English that encompasses the meaning of the original terms,${ }^{2}$ in the following, the concepts involved will be addressed using the indigenous expressions for the said concepts, that is fée (sg.) or fées (pl.) for the Old French texts and álfr (sg.), álfar (pl.) as well as álfkona (sg.) and álfkonur (pl.) for the concept referred to in the Old Norse works. With regard to the overall shared concept involved (in other words an overarching term for the general class of being represented by "fées and álfarlálfkonur"), the English lexeme "fairy-folk" (in quotation marks) will be used here flavorlessly, void of the modern connotations attached to it in the longer, more general introductory and concluding sections. While being another unsatisfactory translation, it nonetheless avoids unnecessary repetition of all of the original terms in each case. Indigenous words and phrases will be given in italicised form to enable them to portray their initial, unspoiled meaning, English translations being provided in brackets.

Before the investigation can be commenced, the etymology of the two main Old Norse and French terms for "fairy-folk" must be addressed, explaining in part how and why certain key characteristics are frequently associated with each of them. The root of the Old Norse álfr, Anglo-Saxon alf and Middle High German alp, appears to be the Indo-European root *albho- meaning "white" (Pokorny 1959: 30). ${ }^{3}$ This stem has cognates in various languages, for example, the Greek $\dot{\alpha} \lambda \phi o ́ s$ ('white rash'), the Latin albus ('white'), the Cymric elfydd ('earth, world') as well as the Old High German albiz (also elbiz), the Anglo-Saxon aelbitu (or ielfetu) and the Old Norse elptr, all of which mean 'swan' (Pokorny 1959: 30).

\footnotetext{
${ }^{2}$ Terry Gunnell has shown that the word álfr has had different meanings attached to it throughout the ages (2007: 111-130).

${ }^{3}$ Jan de Vries has suggested otherwise, namely that the word may derive from the Sanskrit ऋभु (' $r b h u$ ') denoting divine and very skilled artisans (de Vries 1956: 257, n. 2). With regards to $a l f$, see, for example, Peters 1963: 250-257.
} 
Interestingly, Julius Pokorny suggested the terms álfr, celf and alp may initially have denoted "whitish mist shapes" (1959: 30). Whatever the case, clear connections exist with the word 'white' - and therefore a suggestion of brightness and/or fairness - an attribute that will prove to be fairly common to both the álfar, the alfe and the fées, as will be shown in the following.

As Claude Lecouteux has highlighted, the masculine term elf (pl. elfes) has only existed in the French language since the nineteenth century arising as a loan word from German (Lecouteux 1988: 121-122). The original French term for supernatural (albeit usually female) figures of the "fairy" kind was fée (pl. fées). The supposed etymology for the word fée is more nebulous than that for the Old Norse álfr. The first two proposed origins interpret the word as being a derivate of other words or forms. The first idea is that it derives either from the Persian word (sg. pari, pl. نابرب pariān; known in Turkish as peri), which refers to winged spirits that are well-known for their beauty, or from the second syllable - pha of the Latin nympha, a word that ultimately derives from the Ancient Greek word $v v ́ \mu \phi \eta$ (nymphē; 'bride, nymph') (Williams 1991: 462). The other suggestion is that it derived from other words with similar semantic fields, denoting similar concepts, such as the Old English fagen ('joyful, glad') or the Latin fatuus ('silly, foolish') (Williams 1991: 462). The most accepted proposal is that the origin of the word fée lies in the Latin fatum ('things said'), neut. pl. fata (Williams 1991: 462; Simek 2001: 225-226). This word fatum was apparently misunderstood (or reimagined) by some in the Early Middle Ages, the sg. fem. being used for 'fate, female goddess', and later, the matronae (figures of Roman mythology potentially equivalent to the Old Norse dísir) (Briggs 1969: 174 and 1978: 37; Williams 1991: 462; Simek 2011a: 220-223). It is this latter etymology which has led Williams to argue that the initial meaning of the word fairy was 'fatedness' (since he understood the matronae to be goddesses of destiny) (Williams 1991: 472).

The following two sections will consider the medieval perceptions of fées and álfar as well as that of the culturally connected Anglo-Saxon celfe, examining both their shared features and the unique attributes each of these supernatural concepts were seen as having (at different times) in their respective cultures. Following this, the article will go on to consider the problems involved in translating the Old French fée with the Old Norse álfkona, considering the use of these terms in the written evidence, that is in both the translated riddarasogur and the respective French source material. 


\subsection{Fées}

Prior to the emergence of fée-like creatures in the written material, it is evident that various other concepts appear to have been circulating in medieval France, some of which bled into, shaped and/or gave rise to the later perception of the fées. France naturally had its fair share of preChristian mother goddesses and various other local beliefs in supernatural beings that had over time been imbued or transformed by Christianity (Saintyves 1936: 163-170; Walter 1992: 12-16). Indeed, the history of France in the Middle Ages shows many different cultures bringing their culture and (folk) beliefs into the country, making it a fertile breeding ground for a rich inventory of folklore and folk material. In the beginning of the sixth century, various tribes, such as the Franks, Burgundians and Vandals, had ventured into French territories, and these had been followed by Viking raids from the last decade of the eighth century onwards, which concluded with the appointment of Rollo I as Duke of Normandy in 911 (Ferro 2001: 37-40 and 56). All of these naturally introduced a range of new cultural concepts. Additional Muslim influences, propelled by the early Muslim conquests instigated by the prophet Muhammad in the seventh century, became tangible in France in the decade from 720 to 732 (Ferro 2001: 51-52). It was against this tumultuous historical background that the medieval French folk beliefs were taking final shape from the eleventh century onwards.

From the period of the fifth century onward, it is evident that Latin works such as Etymologiae by Isidore of Seville (c. 560-636) and De Nuptiis Philologiae et Mercurii by Martianus Capella (active in the fifth century) use words like fata, nympha or dryades to denote various supernatural beings of the "fairy" kind known in southern Europe. ${ }^{4}$ In scholar-

\footnotetext{
${ }^{4}$ Isidore of Seville, for example, states in Book 8 De Ecclesia et Sectis of his Etymologiae: "Nymphas deas aquarum putant, dictas a nubibus.... Ipsas autem dicunt et Musas quas et nymphas, nec immerito. Nam atque motus musicen efficit. Nympharum apud gentiles varia sunt vocabula. Nymphas quippe montium Oreades dicunt, silvarum Dryades, fontium Hamadryades, camporum Naides, maris Nereides" (Isidori Hispalensis Episcopi Etymologiarum Sive Originum Libri XX 1911: 8.96-97) ("They believe nymphae to be the goddesses of the waters, so called after the clouds. ... Moreover, they also call musae [those] which are nymphae, not undeserved. For, also, [their] motion produces music. Among the pagans exist various names for the nymphae; since they call nymphae of the mountains oreades, of the forests dryades, of the springs hamadryades, of the plains naides, of the sea nereides." [Unless otherwise stated, all translations in this article are those of the author]). In Book $2 \S 167$ of his work De Nuptiis Philologiae et Mercurii, Martianus Capella (fl. c. 410-420) conjures the following image of all kinds of beings living in nature:
} 
ship, such figures are described as fées marraines ('Godmother fées') to highlight their origin and to differentiate this type of fées from another incarnation, namely that of the fées amantes ('lover fées') encountered in later vernacular literature (see below) (Harf-Lancner 1984: 27-34 and 2003: 25-43). ${ }^{5}$ As with the alfar and alfe respectively (see below), it seems clear that the fées and their predecessors experienced demonization under the Christian faith, something that can be seen in, for example, Sermon $X V$ of the collection of sermons entitled Super Apocalypsim by Geoffrey of Clairvaux (also of Auxerre; c. 1115/1120-after 1188) (see sections 1.2 and 1.3 below) (Goffredo di Auxerre 1970: 185; Lecouteux 1992: 83; Harf-Lancner 1984: 411-416 and 420-431 and 2003: 175-180, 205-210 and 214-218). While this had an influence on their presentation - as can be seen in the narratives related to the Chevalier au cygne cycle or the ambivalent development of the figure of Morgan le Fay, for instance this did not seem to impede the popularity of the fées in popular tradition (Harf-Lancner 1984: 184-196 and 390-409 and 2003: 59-65 and 175203). Indeed, over time, a different image of the fée started emerging in the literature of the aspiring social cast of the knights which drew heavily on earlier popular folk motifs and traditions. As Harf-Lancner has argued, it appears to have been this advent of aventure-literature in the twelfth century (represented by, for example, the lais of Marie de France and the chansons de geste; see below) that gave rise to the fées amantes as literary entities (Harf-Lancner 1984: 34-42 and 2003: 47-65). It is worth dwelling on these figures a little longer, for they are the most prominent "type" of fées encountered in the literature considered for this article.

As has been discussed above, medieval France was a cultural melting pot in which Roman, Christian, Muslim and pagan cultures had contributed to a broad variety of different folk beliefs and traditions. In his work La Fée à la Fontaine et à l'Arbre (1992), Pierre Gallais has proposed the idea of an essentially literary archetype for the fées amantes. Gallais argues that this trope consists of a specific set of motifs, namely the idea of a

“... qui habitant siluas nemora ... lacus fontes ac fluuios appellanturque Panes Fauni Fones Satyri Siluani Nymphae Fatui Fatuaque uel Fantuae uel etiam Fanae a quibus fana dicta quod soleant diuinare"(Martianus Capella 1866: 45) [“... which [i.e. the earth] they inhabit forests, woods, ..., lakes, springs and rivers and they were addressed as Pans, Faunuses, Fones, Satyri, Silvani, Nymphae, Fatui, Fatua and even Fantuae and also Fanae after which temples [lat.sg.fanum,pl.fana] are named because they would be used to divine"]. ${ }^{5}$ As late as 1881, Paul Sébillot recounts a story collected in Le Gouray, Brittany, that a group of fées called Margots give presents to newly born infants of nobility and predict their future (Sébillot 1882: 110-111). 
solitary, supernatural woman (the fée) being encountered by the hero of the narrative by a beautiful fountain or a lone tree (a locus amoenus) something which always has consequences (1992: 331; Sébillot 1905: 190-191 and 195-199). He argues that this initial concept of the fée and her connection to woodland is the embodiment of a re-invented and perception of nature re-imagined under a Platonian Demiurg and made prominent by the troubadours and the pastourelle in the twelfth century, an image which was then seized on and developed by other writers in the thirteenth century who gave the fée the shape of the mother of all beauty (Gallais 1992: 326-330). ${ }^{6}$ As Gallais notes:

Pour les romancier "symbolistes" du XIIe siècle et du début du XIIIe, comme pour les conteurs populaires, la Fée à la fontaine, emanation de son locus amoenus, personification des forces naturelles de vie, unissant le charme de la jeune fille à l'efficacité protectrice de la mère, est une representation pure de l'anima. (1992: 332)

(For the 'symbolist' novelists of the twelfth and early thirteenth century, as for the popular storytellers, the 'Fairy by the Fountain', the emanation of the locus amoenus, a personification of natural forces of life uniting the charm of the young girl and the protective efficacy of the mother, is a pure representation of the anima.)

One can summarise the most prominent traits of the medieval French fées as being that besides their supernaturality and femininity and their connection to trees and water, they are fair and possess magical capabilities (divination, prediction of destiny, and illusions) (Sébillot 1882: 73-74 and 1905: 410-414; Harf-Lancner 2003: 214-218). They tend wounds, and, while they are not described as fighting, they are very capable at textile work - both spinning and weaving - as well as the crafting of weaponry and armour (see, for example, Élie de Saint-Gilles discussed below) (Harf-Lancner 2003: 148). Although the above features are not limited to the accounts of fées amantes, they are most prominent in these accounts. Another important aspect that needs to be borne in mind in this respect, however, is the potential connection of the earlier fées marraines

\footnotetext{
${ }^{6} \mathrm{~A}$ pastourelle is a terse narrative that describes a meeting between a knight and a beautiful shepherdess as well as his advances and the outcome thereof from the knight's point of view. The pastourelle was very popular in thirteenth-century France and especially in the Provence (Princeton Encyclopedia of Poetry and Poetics, s.v. "Pastourelle").
} 
with the idea of changelings, something that can be seen most clearly in the association of the fées with childbirth (see above and section 2.2). ${ }^{7}$

The narrative prominence of this type of fées can be roughly said to begin in the twelfth century, gradually fading out in the fifteenth century congruently with the fall of the chivalric class and the literature associated with them. It must be borne in mind, however, that these changes did not only affect the conceptualisations of fées, who were but one of a variety of other supernatural creatures known in France in the Middle Ages (HarfLancner 2003: 239-241).

\section{2 Álfar: An Enigma of the North}

The álfar seem to have experienced a more troubled history of development than the French fées, going through various stages from their earliest appearances, often under influence from other concepts, some of which appear to have been foreign. At one point, we even find them being separated into two distinct groups of beings (light and dark) by the early Icelandic scholar Snorri Sturluson (1179-1241) under apparent influence from the Old Norse translation of the Christian Elucidarius (dated to c. 1200). ${ }^{8}$ The álfar are nonetheless tangible figures in Old Norse textual accounts between the eleventh to the mid-fifteenth century, going on to take an enduring role in Icelandic folklore, even today. ${ }^{9}$

Mentions of the álfar reach as far back as the earliest surviving mytho-

\footnotetext{
${ }^{7}$ The literary and folkloristic fées have amongst their ranks various famous named figures, such as Mélusine and Morgan le Fay. The figure of Mélusine will be of interest in the discussion of the connection of fées and álfkonur as progenitors of lineages (see section 2.4 below). It is nonetheless worth bearing in mind that the mélusienne accounts ("Mélusinian stories") highlight the "positive" aspects of women (such as motherhood, protectiveness, fidelity in marriage), while the morganienne stories on the other hand revolve around features that are perceived as more dangerous (such as magic skills, sexual desire, and deviousness) (Sébillot 1882: 117-119; Gallais 1992: 12; Harf-Lancner 2003: 149, 151-155 and 214-418).

${ }^{8}$ See Skáldskaparmál 1998: 41 and 45; and Elucidarius 1992: 8-11. Various research questions have arisen from Snorri's distinction between the ljós- ('light'-), $d \phi k k$ - ('dark'-) and svartálfar ('black álfar') in Skáldskaparmál, and not least in connection with the description of angles in Elucidarius (See, for example, Holtsmark 1964: 37; Gunnell 2007: 127-128; Hall 2007: 23-27; Simek 2013: 335-336 and 2017a: 211-212). Owing to limitations on length, it is impossible to take this question further here.

${ }^{9}$ As has been recently highlighted by Gunnell, the álfar appeared to have retained some actuality in Icelandic learned works during the late Middle Ages and the Age of Enlightenment (2018: 191-209). Gunnell has also highlighted traditions regarding álfar that are still practised in present-day Iceland (2012: 301-323 and 2014: 338-342).
} 
logical material, the most prominent mentions appearing in the manuscripts of the so-called Poetic Edda in the late thirteenth century, in which the álfar never appear as protagonists. They nonetheless appear frequently in various re-occurring and frequently used formulaic phrases that show their close connections to the two divine lineages, the assir and vanir (Shippey 2005: 177-178; Gunnell 2007: 121-123; Ármann Jakobsson 2015: 216).${ }^{10}$ The Eddic connections between the álfar and the vanir gods nonetheless appear to have had more gravity than the others. For example, the vanir god Freyr is said to receive the world of Álfheimr as tannfé (a gift received upon growing or losing one's first tooth) in Grimnismál st. 5, and the sun which Freyr seems to be closely connected to is referred to as álfrǫðull ('álf-wheel') in Vafprúðnismál st. 47 and Skírnismál st. 4 (Simek 2017a: 208; Motz 1973/1974: 95). These aforementioned links between gods and the álfar in earlier times may also be inferred from the verses the early Icelandic poet Egill Skallagrímsson utters in Egils saga Skallagrimssonar (dated to the first half of the thirteenth century) before he erects a níðstǫng against the Norwegian King Eiríkr blóð $\phi x$ and his associate Queen Gunnhildr, calling on a god about whom he uses the (potentially) synonymous terms landálfr and landáss (Almqvist 1965: 92-93 and 108-109; Jón Hnefill Aðalsteinsson 1999: 153-157), ${ }^{11}$ suggesting that the words áss and the álfr were also synonymous (Gunnell 2007: 121; Ármann Jakobsson 2015: 216). Other surviving secular texts from the same period relating to the history of Iceland nonetheless use the term in a different sense, suggesting a development in meaning. The idea of an álfablót (a seasonal sacrifice to the álfar) is mentioned in st. 5 of the Austrfararvísur of the skáld Sighvatr Pórðarson (995-1045). ${ }^{12}$

Works such as Landnámabók (thought to be composed in the twelfth century) mention beings and concepts such as landvattir (referring to both nature spirits and the spirits of the dead) or bergbuiar ('rock dwellers') and tell of people who were believed to "die into the hills". ${ }^{13}$ At first, the

\footnotetext{
${ }^{10}$ The formulaic use of álfar has been extensively studied, especially with regard to mentions of them in the role of demons and illness-causing entities: see various publications by Rudolf Simek (2011b: 26-47; 2017a: 206-212; 2017b: 140-141).

${ }^{11}$ The reference to landáss is in lausavísa 28 (A-redaction of Egils saga Skallagrímssonar; $l v .27$ in B-redaction; $l v .26$ in C-redaction) and that to landálfr in lausavísa 29 (A-redaction; $l v .28$ in B-redaction; $l v .27$ in C-redaction). The nídstong is erected in chapter 57 in the A-redaction of Egils saga: (Egils saga 2001: 105-106 and 110).

${ }^{12}$ All references to Skaldic poems are to the versions contained in the Skaldic Poetry of the Scandinavian Middle Ages database (https://skaldic.abdn.ac.uk/db.php).

${ }^{13}$ It may suffice to refer to two examples given in Landnámabók, namely the chapters 68
} 
landvattir appear to have been seen as something quite different to the álfar, hinting at the two being quite different concepts, as can be seen in Egils saga (Gunnell 2007: 117). ${ }^{14}$ However, over time a development seems to have started taking place whereby the word álfr was also starting to be used (as now) for beings related to rocks or hólar (Gunnell 2007: 118-119). Such a development can be inferred from a description which is preserved in chapter 9 of Heimslýsing ok helgifraæði contained within the Hauksbók manuscript (composed around 1300), describing how women sacrifice food to rocks to please entities referred to as landvaettir (Hauksbók 1896: 167; Shippey 2005: 182-183; Gunnell 2007: 120). In short, the álfar were becoming landvattir. The best example that highlights this development is the early thirteenth-century Kormáks saga, in which a blood sacrifice to a rock prior to a hólmgangr duel is described as an álfablót rather than making any reference to landvattir (Vatnsdoela saga, Hallfreðar saga, Kormáks saga, Hrómundar páttr halta, Hrafns páttr Guðríðarsonar 1939: 288; Shippey 2005: 183; Gunnell 2007: 118119; Simek 2013: 329 and 335).

From here onwards, the álfar appear to take diverging roads in Christian works, being either classed with other óvattir ('fiends, evil entities') as in, for example, Grettis saga Ásmundarsonar (dated to the early fourteenth century), or even made synonymous with angels (Gunnell 2007: 119-120; Simek 2013: 327-328 and 2017a: 206 and 219)..$^{15}$ The same process of demonization which, as noted above also applied to the fées, is effectively highlighted in various medieval lead amulets that have been discussed by Klaus Düwel and Rudolf Simek (Düwel 2001: 237-252; Simek 2013: 326 and 329-335). The lead amulets in question here are dated to a time between the eleventh and twelfth centuries and have been found in an area spanning Jutland, Schleswig and Halberstadt (in the eastern region of Saxony-Anhalt, Germany). The most interesting incision is preserved on a small lead sheet found in a church in Romdrup near Limfjord, Jutland (Denmark) and is dated to shortly before 1200. It features the following

and 85 (as given in Sturlubók, dated to between 1275 and 1280). Chapter S68 mentions how Sel-Pórir and his retinue think they would die into Pórisbjörg, whereas chapter S85 (H73) imparts how Pórólfr and his kinsmen believe they would die into Helgafell (Íslendingabók, Landnámabók 1968: 94, 96, 98 and 124-126).

${ }^{14}$ From Egill's curse it becomes apparent, that the landvattir he calls upon indwell the landscape rather than living inside mountains, and that they can be subjected to the effects of the nídstong (Egils saga 2001: 110).

${ }^{15}$ Similar ideas can also be found, for example, in st. 2.1 of the so-called "Buslubæn" curse in Bósa saga ok Herrauðs (Fornaldarsögur Norðurlanda 1944: 474). 
adjuratory formula: "adiuro uos eluos uel eluas aut demones ..." ("I conjure you, elves [masc.] or elves [fem.] and demons ..." [Simek 2017a: 215]) (Düwel 2001: 239; Simek 2017a: 215). What is worth highlighting here is the fact that the formula seems to distinguish between male and female elves which the forms eluos ('male elves') and eluas ('female elves'). As will be stressed below, however, this is the only mention of female álfar in the period alongside Fafnismál (see above). It should be borne in mind that inscriptions such as this may reflect the notion of an omnipresence of demonic or malevolent entities in medieval times (Simek 2013: 321-325 and 328-329; 2017a: 213-219 and 2019: 377-386).

Ultimately, it is likely that the brief outline given above only scratches the mere surface of how the alfar might have been perceived in the Nordic countries in the early Middle Ages and how this perception changed over the course of time. One can nonetheless draw some conclusions. As Terry Gunnell has underlined, the obvious multifarious concept of the álfar suggests that, like the fées, these beings cannot be viewed as having constituted a single concrete group like the asir or vanir, for example (Gunnell 2007: 129; Ármann Jakobsson 2015: 216 and 220). They rather appear to represent a broad concept which rejects any attempts to categorise them in simple terms. Their character was evidently both volatile and changeable. The Nordic álfar of the Middle Ages are fittingly be summarised in the following statement by Rudolf Simek:

What must be kept in mind ... is that detailed concepts of what an álfr actually was and did may have varied widely in time and space over the Germanic area, even after the time of the Christianization of the Anglo-Saxons in the seventh century and up until the High Middle Ages, when the álfar were still conjured up, even if to ban them from harming people. (2017a: 219)

It is nonetheless clear that by the time of the translated riddarasogur, the álfar in Iceland were beginning to take on the role that they have maintained since in Iceland, as a kind of nature spirit, albeit one that at this stage was essentially male, and had few connections with magic, childbirth or textile work. As the above quote suggests, similar developments appear to have been taking place in Anglo-Saxon England, both preceding as well as simultaneously to those shifts in the perception of the Nordic álfar that have been outlined above. Naturally, both areas have a similar cultural background, meaning that it is also worth briefly investigating the Anglo-Saxon perception the alfe if we wish to understand the overall background of this concept and its potential for change and adaptation. 


\subsection{The Anglo-Saxon alf/celfe}

The perception of figures associated with the álfar (usually referred to as alf (sg.) or alfe (pl.) in Old English) are tangible in various written accounts from Anglo-Saxon England going back to the eighth century. That the perception of the celfe was as multi-facetted in Britain as it was in Scandinavia can be seen in a variety of sources. A good example is found in the early Old English glosses on various Latin works dating to the ninth and tenth centuries which highlight the existence of a broad variety of "types" of alfe, ${ }^{16}$ driades ('dryads') being described as woodalfenne, and musae ('muses') being described as landalfe among others. One naturally needs to bear in mind that like the translated riddarasogur, these glosses constitute somewhat problematic sources (Hall 2007: 78-79 and 81-83). ${ }^{17}$ All the same, a recurring feature of the Anglo-Saxon alfe (like their Scandinavian counterparts) is their brightness or beauty, as can be seen in the use of the Old English poetic term alfscinu which translates as 'alf-beautiful' (Shippey 2005: 172; Hall 2007: 88-94). The usage of this word can be substantiated on three different occasions, all of them being connected to the description of females (Hall 2007: 92-94). ${ }^{18}$

Negative connotations like those associated with the álfar are also encountered with the alfe, some potentially deriving from their possible association with other, known, antagonistic supernatural beings known in Britain. Indeed, it might be argued that even at this time, the alfe were regarded with more severity in the Anglo-Saxon world than in the Nordic countries, perhaps because of the church which was well established much earlier in Britain (during the sixth to eighth centuries) (Padberg 2009: 74-93). As Alaric Hall, in particular, has shown, in Britain the alfe were frequently interpreted as being the root of physical afflictions. Old English preserves various words for manifold illnesses that are thought to have been caused by alfe, the most prominent of which is alfe gescot ('alf-shot') mentioned at an early point in the well-known late tenth-/

\footnotetext{
${ }^{16}$ See, for example, the Carmen de virginitate by Aldhelm (c. 639-709) (Aldhelmi Opera 1919: 353).

${ }^{17}$ It may suffice to mention one example here, namely the Third Cleopatra Glossary which contains, amongst other texts, Carmen de virginitate by Aldhelm which was discussed above. It thus comes to no surprise that Aldhelm's terminology can also be found in the glossary (Gretsch 1999: 132-184 [especially 140-141]).

${ }^{18}$ The word alfscinu appears two times in Genesis A (1l. 1827 and 2731) and once in Judith (1. 14), (The Anglo-Saxon Poetic Records 1931: 55 and 81 and 1965: 99).
} 
early eleventh-century text commonly referred to as Wið fārstice in the collection of texts known as Lacnunga (Anglo-Saxon Remedies 2001: 90-95; Hall 2007: 96-118)..$^{19}$ The idea is that of a stinging pain induced by an outside (supernatural) force by the means of a shot projectile (Cameron 1993: 140-144). ${ }^{20}$

Of particular interest is, as with the Nordic álfar, that the Anglo-Saxon alfe almost exclusively seem to point to male figures. As has been stated by Hall, it is noteworthy that the glossators of eighth century England used the Latin loanword nympha when referring to potentially female alfe. This suggests that there was no vernacular Old English word for a female counterpart to the alfe (Hall 2007: 83). It is only later, under the influence of foreign narratives, that changes start taking place. One of many examples is Lazamon's description of Queen Argante in his latetwelfth-century Brut which points to the late development of the word alven (to denote specifically female alfe) (Shippey 2005: 175-176; Hall 2007: 75-76). ${ }^{21}$ As Hall remarks:

The rise of the female denotation to alf appears concurrently ..., with the transference to $c e l f$ to the weak declension. But although this morphological change could have been a factor in creating the conditions for semantic change, it is not a sufficient explanation for it: other innovative early Middle English weak plurals like cnihten, kingen or brethren continued to denote males alone. The arrival of female elven in English culture must have involved other factors, linguistic and extra-linguistic. (2007: 88)

As with the Icelandic álfkonur (see below), the elven should thus be seen as additions that were introduced at a later stage when the concept of the male alfe (and álfar) had been established for many centuries. It is tempting to speculate whether this development, like that in Iceland, was prompted by the influence of Anglo-Norman, Breton or generally French literature like that which will be considered in the following section.

\footnotetext{
${ }^{19}$ Regarding the dating of Harley MS 585 which contains the Wið fērrstice text, see http:// www.bl.uk/manuscripts/FullDisplay.aspx?-ref=Harley_MS_585. The belief that ailments or even death could be caused by elvish projectiles remained popular even in later centuries in the British Isles (Hall 2005: 19-36).

${ }^{20}$ Similar ideas are found in the Nordic countries, as has been pointed out by ReichbornKjennerud (1928: 51 and 87-88) and Lauri Honko (1959: 41-48).

${ }^{21}$ In his twelfth-century work entitled Brut, Lazamon describes Queen Argante in 1.28613 as aluen swiðe sceone ('an elf most fair') and in 1.28639 as fairest alre aluen ('the fairest of all elves') in the Cotton Caligula A.ix. manuscript (Lazamon's Brut 1847: 144-145).
} 


\section{Of Magical Beings and Where to Find Them}

\subsection{Introduction}

As has been stated in the introduction, the aim of this article is to research the changes and alterations in concept that took place as the Old French term fée was translated to the Old Norse álfar and álfkona in the translated riddarasogur. Since translation usually involves translocation (even if it is as abstract as text or language), it will often involve concepts being moved from one culture to the other. This seems to have been particularly the case in this example since, as has been noted above, the image of female alfar is almost totally absent in both textual as well as archaeological evidence in the Nordic countries prior to the arrival of the translated riddarasogur and their continental motif inventory (see above). There is thus good reason to consider whether that the concept of female álfar was introduced into the Old Norse sphere through intercultural interactions between Scandinavia and the Continent in the thirteenth century, at a time when the fées had already manifested their position as narrative devices in France (see above).

This naturally brings us to the question of which narratives and the translations should be included in the current investigation. Logically, those Old French narratives that have no surviving Old Norse translation (regardless of whether any translation ever existed) are excluded, as are those translated riddarasogur that do not feature the word álfkonal álfkonur in their Old Norse rendition. Thus, narratives of this kind are not considered here, with the exception of the Breton lai Guigemar which features the only description of a woman as being "beautiful as a fée" (Sinaert 1984: 61) which has been transported into the Old Norse corpus of translated riddarasegur.

The sources upon which the following investigation rests are thus limited to four French works that feature fées and their respective Old Norse redactions: ${ }^{22}$

- Érec et Énide, surviving in thirteen manuscripts (two of which are fragmentary) and generally dated to c. 1170 , and the translation

\footnotetext{
${ }^{22}$ Unless otherwise stated, all information regarding the various Old Norse manuscripts, such as their dating and the number of extant manuscripts are taken from the Ordbog over det Norrøne Prosasprog database (http://onp.ku.dk/onp/) and from Sif Ríkharðsdóttir and Stefka G. Eriksen (2013: 24-25).
} 
Erex saga dated to the mid-thirteenth century, which is extant in three manuscripts dating from the sixteenth century (Erec et Enide 1968: III-VI and XXVIII-XXXII; Erex saga 1999: 219-220). The narrative follows the Arthurian knight Érec (Erex) who finds his wife Énide (Evida in Old Norse) during his first adventure and, giving in to love, loses sight of his chivalric duties. He is urged on to a second series of quests by his wife which leads to his reinstatement in rank and glory.

- Élie de Saint-Gilles, which survives only in the BnF 25516 manuscript $^{23}$ which is dated to the latter two decades of the thirteenth century, and the translation Elís saga ok Rósamundu (henceforth Elís saga), which has been preserved in over forty manuscripts dating from between the thirteenth to the eighteenth centuries. The original translation is dated to the first half of the thirteenth century (Élie 2013: 9-10; Elis saga 1881: VII-XVII). The story tells how Elye (Elís), the son of a Provençal ruler named Julien (Juliens) is reprimanded for being an unpromising knight and leaves his father's court. During his travels, he rescues four Christian knights but gets captured in the process. Elye manages to vanquish the antagonistic king Lubïen de Baubas (Jubien) with the help of the pagan princess Rosamonde (Rósamunda), who promises to be baptised and the two return to France. (The Old French original continues, making Elye the godfather of Rosamonde. While some Icelandic translations break off here, other later renditions have the two marry.)

- Le mantel mautaillé (also known as, for example, Le court mantel), surviving in six manuscripts and dated to the late twelfth / early thirteenth century, and its close Old Norse translation Mottuls saga, dated to the mid-thirteenth century, and surviving in six manuscripts (The Lay of Mantel 2013: 5 and 7-8; Mottuls saga 1999: 3-4). The story tells of how a stranger brings a mantle to Arthur's court, offering it in reward to any lady that it fits. However, the mantle has been enchanted, becoming either too long or too short whenever the maiden in question has been unfaithful to her love, something which humiliates almost every woman at court until one finally proves worthy.

\footnotetext{
${ }^{23}$ For a description of the manuscript BnF 25516 located in the Bibliothèque national de France, Déparement des Manuscrits (National Library of France, Department of Manuscripts): see (in French) https://archivesetmanuscrits.bnf.fr/ark:/12148/cc71766w.
} 
- The Breton lai Guigemar attributed to Marie de France, surviving in four manuscripts, and dated to the later decades of the twelfth century, and its two translations Guiamars ljó contained within the Strengleikar compilation (and preserved in two fragmentary Norwegian manuscripts dated to the thirteenth century) and Gvimars saga (extant in the Icelandic Lbs 840, $4^{\text {to }}$ manuscript which is dated to 1737) (Die Lais der Marie de France 1925: LX-LXI and LXIV; The Lais of Marie de France 2009: 8; Gvimars saga 1979: 108-109 and 112-120). ${ }^{24}$ This tells how the outstanding knight Guigemar (Gviamar or Gvijmar) gets wounded during a hunt, then finding a fair woman and following her to her realm. He takes his leave after being healed. His love follows him some time later but is captured by the king Mériaduc (Meriadus). Guigemar then vanquishes Mériaduc, takes over his kingdom and rescues his beloved.

The scenes in which the fées (álfkonur in the translations) appear can be roughly grouped into three groups which will be covered in the following sections which will focus on: 1) craftsmanship; 2) the bestowing of fate and changelings; and 3 ) beauty.

\subsection{Fées and álfkonur as Exceptional Craftswomen}

That both the fées and the Icelandic álfkonur of later times are seen as being exceptionally skilled in the art of crafting objects, ranging from wonderful clothes and shoes to magical items has been long accepted. It thus comes to no surprise, that the translated riddarasogur and their respective Continental sources that feature such beings in their narratives after make use of these tropes in order to explain the origin of magical objects. Three of the four narratives that involve fées and/or álfkonur show them as supernatural artisans who produce either beautiful and exquisite or magical objects (four times a mantle and once a weapon).

No better point of departure for such an investigation can be found in Old French chivalric literature than in the elaborate description of a mantle given in Chrétien de Troyes' Érec et Énide 11. 6671-6743 (Erec et Enide 1968: 203-205). The description is given as part of the coronation

\footnotetext{
${ }^{24}$ Regarding the difficult transmission history and the interdependence of the manuscripts and the possibility of Gvimars saga being acutally closer to an original than the extant Norwegian manuscripts (Brügger Budal 2014: 40).
} 
scene of Érec, in which he receives the piece as one of his coronation gifts. The account opens by describing the mantle's origin, namely that it was fashioned by four fées, and then continues with an in-depth description of the embroidery with which the mantle was adorned, ${ }^{25}$ depicting the four liberal arts (also known as quadrivium): geometry, arithmetic, music and astronomy (in that order), each fée being responsible for the crafting of one illustration (Erec et Enide 1968: 203-205).

Erex saga contains a loose translation of this passage, although interestingly enough, here Evida is granted the mantle instead of Erex. The corresponding passage, which is not as exhaustive as its French counterpart, runs as follows:

Artús kóngr gaf Erex kórónu af gulli gerva í vígslunni ... En Evida gaf hann [that is King Arthur] dýrliga skikkju; par váru á skr<i>faðar allar höfuðlistir. Hún var öll skínandi ok svá dýr at engi kaupmaðr kunni hana at meta. Hún var ofin níu rastir í jörð niðr af fjórum álfkonum í jarðhúsi, par er aldri kom dags1jós. (Erex saga 1999: 258)

King Arthur gave Erex a crown of gold at the consecration ... But to Evida gave he [that is King Arthur] a precious robe; on it were depicted the liberal arts. It glittered all over and was so precious that no merchant could estimate its value. It was woven by four [álfkonur] in an underground dwelling nine leagues under the earth where no daylight ever reached. (Erex saga 1999: 259)

A striking point in this translation is that fact that the Old Norse deviates in its depiction of the álfkonur working in the darkness below the surface of the earth - an aspect one might associate rather with dvergar - something that the Old French does not mention. The translator thus seems to be building on Snorri's idea of the svartálfar, rather than álfar, who, as noted above, tended to be associated with light.

Another account that features fées as craftswomen is the Old French lais Le mantel mautaillé, in which another very prominent magically induced mantle serves as the driving force for the narrative. This mantle was also meticulously woven by a fée as the following vivid description shows (11. 193-211):

$\mathrm{Si}$ en a tret fors .I. mantel;

Onques nus hom ne vit tant bel,

${ }^{25}$ L1. 6682-3 describe the origin of the mantle: "Quatre fees l'avoient fet / par grant san et par grant mestrie” (Erec et Enide 1968: 203) (“... It was woven / By four fairies, working / As great and masterful craftsmen" [Erec and Enide 1997: 212; here 11. 6747-9]). 
Car une fee l'avoit fet.

Nus hom ne savroit le portret

Ne l'uevre du drap aconter.

Or lesson de l'ovraigne ester,

Si vos dirai une merveille

A qui nule ne s'apareille:

La fee fist el drap une oevre

Qui les fausses dames descuevre.

La dame qui l'ait afublé,

Se ele a de riens meserré

Vers son bon seignor, s'ele l'a,

Li manteaus bien ne li serra.

Et des puceles autresi:

Cele qui vers son bon ami

Avra mespris en nul endroit,

Ja puis ne li serra a droit,

Qu'il ne soit trop lonc ou trop cort. (The Lay of Mantel 2013: 68)

And drew out from it a mantle;

No one has ever seen one so fine,

For a fairy had made it.

No one could describe it.

Or account for the workmanship in the cloth.

Let us now forget the workmanship,

And I shall tell you a marvel

That has no equal:

The fairy incorporated into the cloth a device

That reveals unfaithful ladies.

If the lady who has put it on

Has done wrong in any way

Towards her good husband, if she has one,

The mantle will not fit her properly.

And the same for the maidens:

Any one of them who towards her beloved

Has erred in any respect

Will find that it will never fit her truly,

Without being too long or too short. (The Lay of Mantel 2013: 69)

The corresponding passage in Mottuls saga, features a close translation of the Old French section and reads as follows:

Penna [that is the mantle] gerði ein álfkona með svá mörgum ok ótrúanlegum hagleikum at <í öllum peim fjölda, er par váru saman komnir hagra manna ok hygginna, fanz eigi sá er skynja kunni með hverjum hætti klæðit var gert. Pat 
var allt gulli ofit með svá fögrum laufadráttum at aldri váru ein önnur pvílík sén, pvíat engi kunni finna enda né upphaf, ok petta á ofan sem kynligast var, at peir sem gerast hugðu at, peir gátu sízt fundit hversu sá hinn undarligi hagleikr var samtengdr. (Mọttuls saga 1999: 12)

An [álfkona] had fashioned it [that is the mantle] with such great and inconceivable skill that in that whole assembly of skilful and intelligent men gathered there, there was no one who could perceive in what manner the garment had been made. It was shot through with gold in a pattern of such beautiful embroidered leaves that never the like was seen, for no one could find either the beginning or the end. What was strangest, moreover, was that those who scrutinized it most closely could least discover how that wondrous piece of workmanship was put together. (Mọttuls saga 1999: 13)

Mottuls saga then goes to great lengths to establish for the audience that the court and especially the ladies in the court understood how the background of the mantle came about and what the spell it was imbued with causes ${ }^{26}$ resulting in no lady being interested in owning it (Mottuls saga 1999: 16-17).

In short, both accounts iterate the same qualities - the fairy-esque origin of the mantle, the magic spell that was woven into the cloth, its beauty and the outstanding craftsmanship that goes along with it - encapsulated in the same narrative frame that the said mantle is used as a means of compromising the women at King Arthur's court. ${ }^{27}$

\footnotetext{
${ }^{26}$ The saga explains the nature of the mantle as follows: "En álfkonan hafði ofit pann galdr á möttullinn at hver sú mær sem spilz hafði af unnasta sínum, pá mundi möttullinn pegar sýna glæp hennar er hún klæddiz honum, svá at hann mundi henni vera ófsíðr eða ofstuttr, með svá ferligum hætti at pannig mundi hann styttaz at hann birti með hverjum hætti hver hafði syndgaz" (Mọttuls saga 1999: 12) ["The [álfkona] had woven a charm into the mantle so that the misdeed of every maiden who had been intimate with her beloved would be revealed at once when she dressed in it: it would become very long or very short in a flagrant manner so as to reveal how she had sinned" (Mǫttuls saga 1999: 13)].

${ }^{27}$ It is interesting to note here, that an indigenous riddarasaga from the fourteenth century, Samsons saga fagra, mentions a similar mantle of supernatural origin and powers that, according to the saga itself, echo those of the mantle in Mottuls saga (referred to as Skikkju saga). The mantle in Samsons saga fagra nonetheless appears to be different from that in Mottuls saga in numerous aspects: It is said to have been 18 years in the making before it was considered finished by four álfkonur below the earth in a hellir ("cave"). The four álfkonur are here said to be the daughters of the purs Krapi, retainer to King Skrímnir of Jotunheimr, and are said to operate a weaving mill. The mantle is described as having various natures. For example, it shows when women break their oaths or are indolent to their tasks and shortens when the respective lady gives herself to an extramarital lover (Samsons saga fagra 1953: 31,34, 36, 40 and 47). The same mantle also occupies a focal position in Skikkju rímur (Aðalheiður Guðmundsdóttir 2017: 342 and 347).
} 
Interestingly enough, Elís saga features an additional description of a mantle or cape, worn by Elís' lover Rósamunda which is not featured in Élie de Saint-Gille. The description occurs when Rósamunda is asked to appear before her father King Malkabres of Sobrieborg because his rival King Jubien has demanded that Malkabres not only pay tribute to him but also give him Rósamunda in marriage. Rósamunda dresses herself in her best attire before entering the throne room only to reject Jubien's demand. The description of her garment is the following:

en mottull sa hinn litli, er hon toc yfir sik, var sendr uestan or hæiðinni undan solar setu, or landi pui, er hæiter Occidens; priar alfkonur vafu pat klæði praðum hins bezta gullz með allzconar haglæiki með sua miclum uirkðum, at per satu yfir IX vetr pessu klæði, fyrr en full ofit væri. pessi mottull var allr ofinn storum fuglum, allr með gulli, oc setr hinum agætostum gimstæinum. (Elis saga 1881: 86)

(And the small mantle that she pulled over herself was sent westwards from the pagan world below the sunset, from the country which is called Occidens; three álfkonur weaved this cloth with threads of the best gold, with sundry skill and with such great carefulness that they set over this cloth for nine winters before it had been completed. This mantle was embroidered with large birds, all with gold, and edged with the most beautiful gemstones. $)^{28}$

In the original, the Old French version only describes the mantle as being the gift of a wealthy emir (clearly foreign origin) to Rosamonde, stating that it took a considerable effort to produce such attire. The account lacks any reference to fées in particular (11. 1693-1700):

S'est faite la puchele gentement atorner:

En son dos a vestu .I. hermin engoulé,

D'une lasnete d'or ot estrais les costés,

Unes cauches molt riches, solers bien pointurés;

Un mantel covoitous ot a son col jeté:

Uns rices amiraus li ot fait presenter,

.III. ans mist on a faire, ains que fust parovrés,

Et fu d'un cabetenc tout environ ourlés. (Élie 2013: 214)

And she had herself nobly attired.

She put on a collared ermine robe -

${ }^{28}$ The above cited passage is from Elís saga as preserved in the De la Gardie, 4-7 fol. manuscript. It might be noted that variant readings offered in other manuscripts, replacing the amount of álfkonur with four (Holm. perg. 7 fol.) or omitting the number entirely (Holm. perg. 6, 4to) and changing the time it took to create the mantle to seven instead of nine years (Holm. perg. 7 fol.) (Elis saga 1881: 86-87). 
With a golden cord she had bound the sides -

And wore rich hose and exquisitely-painted slippers.

She put around her neck an envy-inspiring cloak

A gift from a powerful emir.

It was [three] years in the making before it was completed.

Its expensive cloth was embroidered all around. (Elye 2011: 111)

This leaves us with an interesting question: Why add álfkonur when the original does not feature fées in this specific section? Is the translator simply borrowing the motif from Chrétien de Troyes (or elsewhere) as a means of underlining the wonder of the garment? Is this similar to the oral tradition where formulaic motifs are commonly added to extend a scene (Lord 1981: 130-131 and 138)? Is it a borrowing of motifs from elsewhere since the details are otherwise in the written saga?

The Élie de Saint-Gille narrative nonetheless does elsewhere feature fées that are skilled in the art of crafting objects. In this particular case, however, it is not a textile that is beautifully woven or has a spell woven into it as in the case of Le mantel mautaillé and Mottuls saga. In this case it is a staff or cudgel which Elie's henchman Galopin is said to go into battle with and is made by fourfées on an isle in the ocean (11.2370-2374):

Quant Galopins le vit, li preus et li senés,

Rosamonde la bele a congiet demandé.

De la tor avala les marberins degrés,

En la bataille entra, coureçous et irés.

En sa main le baston, $u$ tant a richetés,

Que les fees ovrerent en .I. ille de mer. (Élie 2013: 238) ${ }^{29}$

When Galopin saw him [that is Elie in grave danger], the worthy and wise man,

He asked leave of the beautiful Rosamonde.

He ran down the marble steps of the tower,

He entered the battle, angry and sorrowful.

In his hand was the richly decorated staff,

Which fairies had made on an island in the sea. (Elye 2011: 155)

${ }^{29}$ The motif of crafting fées working on an island in the sea seems to also be used employed in the Continental Version I (dated to the thirteenth century) of the Beuve de Hamton in which the fées craft a hauberk (a section is not in the Anglo-Norman version or Bevers saga) which runs as follows (11. 7522-7527): "Vest un hauberk qui molt fist a löer, / Fees le fissent en un ilse de mer, / D'or sont les mailles, d'argent sont li clavel ..." (Der festländische Bueve 1911: 248) ("[He] dons a hauberk which many would praise / fées crafted it on one island in the sea / The meshworks are made of gold, the rings are made of silver"). 
It is noteworthy, however, that in this case none of the Old Norse redactions feature a correlating passage. While the idea of Elís fighting certainly exists in the Old Norse translation, the remark with regard to Galopin's cudgel does not.

In a brief excursus it might be added that Tristrams saga ok Ísqndar features an episode in which Tristram receives his utmost stalwart hunting hound from a Polish duke as a reward for ridding the duke's dominions of a jotunn (with regards to the information presented in this paragraph see Tristrams saga 1999: 152-159). The duke is said to have himself received the dog as a token from an alfkona from the island of Polin in Álfheimr. The hound is of wondrous colours, has a soft fur and a sweet-sounding bell attached to his collar, all of which makes Tristram forget his sorrows. Unfortunately, due to their fragmentary nature, both the Tristan of Béroul (active in the late twelfth century) as well as that of Thomas d'Angleterre (fl. c. 1170-1180) do not preserve this episode. Thus, the significance of this story remains questionable.

Considering the translations of passages in which fées appear as craftswomen in the stories noted above from a Scandinavian perspective, one might argue that on the basis of the local tradition it would have been more natural for the translations to show powerful magical women or sorceresses crafting these cloths rather than álfkonur. Certainly, the image of women crafting noteworthy clothing is not uncommon in saga literature dating to roughly the same period of the translations (albeit in other sagas than the translated riddarasogur), be the clothing normal or magically enhanced. For example, Landnámabók mentions the two women Hildigunnr Beinisdóttir (S75/H63) and Ljót, mother of Hrolleifr enn mikli (S180/H147).$^{30}$ While Hildigunnr is said to craft clothing twice, the kyrtill ('tunic') of Hrolleifr may be inferred of having been made by Ljót. However, the clothes' feature seems to be that they are impenetrable by iron. Furthermore, one might think of the cloth described in the late $13^{\text {th }}$-century Qrvar-Odds saga,,$^{31}$ or Ragnars saga loðbrókar, ${ }^{32}$ where

\footnotetext{
${ }^{30}$ All following information with regard to Landnámabók is taken from Íslendingabók, Landnámabók (1968: 106-107 and 220).

${ }^{31}$ While in Ireland, Oddr raids the underground home of four women, the fairest of which he intends to take hostage. However, the woman offers a magical shirt in exchange for her freedom, the magical qualities of which are manyfold and include the wearer not becoming hungry and sleepy as well as being invulnerable to sword strikes unless he flees (Fornaldarsögur Norðurlanda 1944: 313-314).

${ }^{32}$ Before departing on his last raid, Ragnar is said to be given a shirt by his wife Áslaug.
} 
the clothes are admittedly practical rather than beautiful or intricate. All the same, the changing of the amount of álfkonur crafting Rósamunda's mantle from the Old French four to the more local number three, does show a more effective adaptation of foreign ideas to local ones, three (or a multitude of it) being apparently a commonly used number in Old Norse and especially when it comes to powerful women. ${ }^{33}$

Be that as it may, the problematic scene featured in Élie de Saint-Gille and dropped in Elís saga in which fées manufacture a cudgel on an island still remains. As noted above, the álfar are not connected to the crafting of weaponry. One might thus be forgiven for assuming that the translator, with a Nordic audience in mind, avoided a direct translation as it did not reflect the culture and worldview of Scandinavian recipients. Granted, such a contemplation only retains validity if the manuscript/manuscripts that served as a template for the saga definitely featured this scene. However, as said, since Élie de Saint-Gille only survives in one manuscript, we may most likely never know whether there were other versions of this story which make no mention of such an origin of Galopin's weapon and might have served as a model for the Old Norse translations. All the same, however, it is clear that the introduction of álfkonur into the Old Norse literary inventory is new, as is the idea of them living underground - a motif that clearly caught on in both the sagas and folklore (see further below).

\subsection{Fate and Stature}

The investigation will now turn to consider the textual instances in which fées and álfar respectively are associated with the bestowing of fate on Galopin in both Elye de Saint-Gille and Elis saga.

The story tells how during his adventure, Elye encounters four robbers and asks to share their meal, which they agree to. They nonetheless request his steed in payment, something Elye adamantly refuses. In the ensuing brawl he brutally slays two of the robbers while the third flees into the woods. The remaining man falls to his knees begging for mercy. In his

The shirt is said to make him invulnerable to sword blows (Fornaldarsögur Norðurlanda 1944: 132-133; Finnur Jónsson 1973: 257).

${ }^{33}$ Regarding the importance of the triad in connection with powerful women, see, for instance, in Voluspá st. 20 the three nornir or the pursar meyiar ('purs-maidens') in st. 8 and the thrice burned and thrice reborn Gullveig in st. 21. See furthermore, for example, Schück 1941: 22-29 and Wagner 1980: 202-208. 
appeal for clemency, the thief reveals his identity as Galopin, recounting the fate that has befallen him (11. 1183-1191). The Old French passage runs as follows:

A l'ore qui fui nés ceste paine m'avint:

.IV. fees i ot; quant vint al departir,

$\mathrm{Li}$ une me voloit a son eus detemir,

Mais les autres nel vaurent endurer ne soufrir,

Et prierent a Dieu qui onques ne menti

Que jamais ne creüsse, tous jors fuisse petis,

Se n'eüsse de lonc que .III. piés et demi,

Et s'alaisse plus tost que cheval ne ronchin.

Certes, et je si fac, por voir le vous plevi. (Élie 2013: 197)

At the hour I was born, this tragedy befell me:

Four fairies were present. When it came time to take leave, one of them sought to keep me as her servant.

But the others wouldn't endure or bear it,

And they prayed to God, who never told a lie,

That I'd never grow more than three and one half feet in height,

And that I'd run faster than a warhorse or packhorse.

Believe me, I swear it's true ... (Elye 2011: 77)

In short, in the Old French three fées who come to the birth quarrel with a fourth who wishes to take Galopin as an apprentice, prays that God will curse him with restricted growth while granting him equine swiftness. This idea of quarrelling fairies would of course be reflected later in the start of the German folktale Dornröschen or Sleeping Beauty (ATU 410) collected by the Grimm brothers, in which twelve fairies are invited as guests at the birth of Beauty, while a thirteenth is not invited owing to the lack of cutlery (Grimm and Grimm 1812: 225-229). ${ }^{34}$ As in Elye de SaintGille, the evil fairy curses while the others attempt to mitigate the curse. In Elís saga, the correlating passage runs as follows:

Sem moðir min hafði fœett mik, pa toku mik i brott um nottina priar alfkonur or buri pui, sem ec var i lagðr, oc villdi æinn af pæim raða mer oc hava með ser; en hinum firer potti tuæimr, oc mællti pa huar pæirra til annarrar, at ec skyllda alldre upp vaxa ne mikill verða, en sua mikit laupa skyllda ec, at alldregi skop guð pat kuikuendi, er iammikit ma fara. (Elis saga 1881: 65)

(After my mother had given birth to me, then three álfkonur took me from the

\footnotetext{
${ }^{34}$ Charles Perrault collected a French variant of this tale in 1696 called La Belle au Bois
} Dormant, in which the number of fairies is seven (Perrault 2012: 342). 
cradle in which I had been laid, and one of them wanted to command me and have me with her; but this displeased the other two, and one said to the other that I should never grow up nor become large, yet should run faster than any other being that God had created.)

While the above passage does not preserve the correlation about Galopin's agility to horses, it otherwise for the main part follows the Old French closely except for the fact that the number of álfkonur is once again given as three (the B-redaction, however, keeps four álfkonur). Another interesting deviation made in the Old Norse saga away from the Old French source text is that the saga omits the invocation of God's curse by the three fées, the mention of God here being transferred to the animals $\mathrm{He}$ has created. It is possible that the translators feared this might hint at a connection of the fees/álfar to God (and therefore Christianity) which Old Norse beliefs did not reflect. ${ }^{35}$

It is worth bearing in mind the fact that here, once again, new talents are being bestowed on álfar: In Old Norse belief, while the role of deciding fate at birth is given to females (often three as in Voluspá st. 20), it is traditionally in the hands of nornir. Also worth noting, is the way in which the Old Norse subtly alters small details. As pointed out above, the Old French describes the fées as being present at Galopin's birth (the fées marraines trope: see above), while in the Old Norse account the álfkonur steal Galopin after his birth, changing the overall topos entirely into one potentially relating to changelings. Nevertheless, as Roger Sherman Loomis pointed out, the Old French section presents a picture that closely resembles the visit of the nornir at the birth of Helgi Hundingsbani as described in Helga kviða Hundingsbana in fyrri sts 2-3 (Loomis 1959: 108). Be that as it may, as Séamas Mac Philib has pointed out, this theme (ML 5085) is found in both Celtic and Germanic folk narratives (Christiansen 1958: 109-113; Mac Philib 1991: 121). It deals essentially with the abduction of a human child, which is replaced in its

\footnotetext{
${ }^{35}$ If we focus on the missing invocation of God in the Old Norse variants, it is worth noting that in the Old Norse world figures such as the nornir are the figures most commonly linked to the concept of fate in Old Norse beliefs. Álfar seem not to ever have such a function. As an example for the connection of nornir and fate, one may quote Fáfnismál st. 11 which offers the term nornar dómr ('The Judgement of the Norns') as a kenning for death: “"Norna dóm pú munt fyr nesiom hafa / Oc ósvinnz apa; / Í vatni pú drucnar, ef í vindi rœr: / Alt er feigs forað"” (“"The judgement of the norns you'll get in sight of land, / and the fate of a fool; / you'll drown in the water even if you row in a breeze; / all fate is dangerous for the doomed man"' [The Poetic Edda 1996: 159]).
} 
manger by an elven changeling, which can range from an (old) elvish man or child to a simple log of wood. Scholars such as Mac Philib, Susan Schoon Eberly and John Lindow have all suggested that this idea tries to culturally and logically explain why some children may be born deaf, mute or with deformations (Mac Philib 1991: 131). ${ }^{36}$

It seems safer to assume this section in Elís saga shows a subtle movement away from the unnatural idea of álfar deciding fate to a more local tradition of nature spirits stealing children, an idea that became very popular in more recent times in Iceland. One might even go so far as to suggest that this brief episode in Elís saga is one of the earliest (if not the earliest) account of a changeling narrative in the Old Norse record. However, in later Icelandic folktales, it is evident that the idea of changelings came to be associated with the notion of the later huldufolk/álfar. ${ }^{37}$

One nonetheless wonders why the translator chose álfkonur and not nornir if they wanted to follow the original text directly? ${ }^{38}$ Was the passage deliberately altered in an attempt to suit Nordic expectations (nornir never being closely associated with the fates of the lower classes in Old Norse texts)? This is worth further investigation.

\subsection{Beauty and Seduction}

It has been stated at the outset that narratives involving to the F302 (Fairy Mistress) motif would not be considered due to the absence of references to the women as fées in the French source texts. The exception is Guigemar, a Breton lais attributed to Marie de France which features the only characterisation of a woman as being as beautiful as a fée, which was also rendered into Old Norse in the translation. Two extant Old Norse translations have been preserved: one is Guiamars ljó preserved in the Strengleikar compilation, the other being Gvímars saga (see above). The

\footnotetext{
${ }^{36}$ Regarding the possibility of disabilities influencing folk beliefs in generally and changelings in particular, see Susan Schoon Eberly (1988: 58-77) and John Lindow (2008: 218 and 232).

${ }^{37}$ See, for example, the stories given by Jón Árnason in the section dedicated to stories regarding álfar, huldufólk and umskiptingar (“changelings") (Jón Árnason 1862: 40-45). The earliest surviving mention of the term huldufólk can be traced back to around 1500 in Jarlmanns rimur, as Haukur Porgeirsson has pointed out (Haukur Porgeirsson 2011: 53). And as can be seen from the material presented above, the use of the term álfar is older.

${ }^{38}$ It is worth noting that the only connection between alfar and nornir is made in the earliernoted Fáfnismál st. 13 where Fáfnir describes how some nornir are álfkunngar (i.e. from the álfar lineage).
} 
reason why these works will be considered here is because they are the only instance of a correlation between álfkonur and beauty in the corpus of translated riddarasogur.

The section of interest in Guigemar happens after Guigemar and his lover become separated and her ship runs ashore in Brittany with the wreck being subsequently discovered and searched by the local king Mériaduc. He finds Guigemar's lover inside the wreckage and is stunned by her beauty which is akin to that of a fée (11. 699-706):

Il [that is Mériaduc] descendi par un degré;

sun chamberlain a apelé.

Hastivement a la nef vunt;

par l'eschiele muntent a munt.

Dedenz unt la dame trovee,

ki de belté resemble fee.

Il la saisist par le mantel;

od lui l'en meine en sun chastel. (Die Lais der Marie de France 1925: 33)

He [that is Mériaduc] went downstairs

and called his chamberlain;

quickly they went to the ship,

climbed up its ladder;

inside they found the woman

who had a [fée-]like beauty.

He took her by the cloak

and brought her with him to his castle. (The Lais of Marie de France 2009: 49)

The same segment is fairly accurately rendered in Guiamars ljóð as follows: "oc gængo [that is Meriadus and a servant] pæir pa baðer skyndelega ovan til skipsens. oc fundu pæir par æina friða fru sæm alfkona være. oc tok hann pa i skikkioskaut hænnar oc læidde hana með ser i kastalann" (Strengleikar 1850: 11-12) ("and then they both went quickly down to the ship and found there a woman as beautiful as an álfkona would be. And then he took the skirt of her cloak and led her with him to the castle"). The same holds true for the account given in Gvimars saga which is almost identical: “... og geingu peir [that is Meriadus and a servant] pä skindelega ofan til skipsens og fundu par svo frijda frü, sem älfkona være, tök hann pä i sckickiu skaut hennar og leidde hana med sier til kastalans ..." (Gvimars saga 1979: 134) (“... and then they went quickly down to the ship and found there such a beautiful woman as an álfkona would be. Then he took the skirt of her cloak and led her with him to the castle.") 
Both accounts thus echo the idea of the Breton lai that the beauty of Guigemar's lover is like that of a fée. Following the original, both Old Norse translations then go on to explain how Meriandus' court marvels about her beauty, further underlining the implicit attribute the lady's exceptional fairness.

The fact that the Old Norse renditions translate this passage accurately without alterations underlines that the concept caused no problem, since, as noted above, the Scandinavian sphere already attributed alfar with beauty.

\section{Conclusion}

The above investigation has considered the way in which the concept of the magical creative álfkona was brought into Old Icelandic in the mid$13^{\text {th }}$-century as a result of the translation of Continental romantic works which demanded the creation of conceptual terms that had not previously existed in the indigenous cultural vocabulary of the north. Apparently, the use of the word álfkona as a translation for fée rather than any other term was not seen as being problematic with regard to the local understanding of the álfar in Iceland at this time, as they were already beginning to blend with nature spirits. Nonetheless, it did involve the introduction of a female equivalent to a group of figures that were previously largely male like the dvergar if we trust the evidence of the Eddic poems and Snorra Edda. This motif of a specifically female sex of álfar had clearly entered the Scandinavian realm by the thirteenth century. As has been shown, these new figures are intrinsically connected to textile weaving and the crafting of beautiful magical garments. That this motif seems to have occasionally been adapted to local beliefs can be seen from the changing of the numbers of the álfkonur in the account of Galopin's fate demonstrated above, a development which is worth further investigation.

There nonetheless appears to have been more wariness with regard to the adoption of the seen attributes of prophecy, cursing and fate associated with fées. These were abilities commonly associated with nornir rather than álfar in the Old Norse worldview and were thus clearly unfitting for the álfkonur.

Equally intriguing, however, are other motifs that may well have come from the translated riddarasogur if they had not come from the folklore 
blend of álfar and landvattir: this was the idea of beings being taken into mountains (also referred to as bjergtagning in later folk legends) ${ }^{39}$ something that builds on the idea of alfkonur working below the surface of the earth in some of the accounts given above, as well as the changeling motif (ML 5058), ${ }^{40}$ which would prove to be a very rich idea in folkloric literature. As has been shown above, the Old French version of Elye de SaintGille has four fées arguing about one of them wanting to have Galopin as her servant. While the Old Norse transports this general idea, the motif of the fées' argument at his birth is changed to the idea of the álfkonur stealing him after Galopin being born. It nonetheless needs to be borne in mind that unlike later Icelandic folk stories such as the famous " 18 barna faðir í Álfheimum" ("The Father of 18 Children in Álfheim") or "Tökum á, tökum á" ("Let's seize it, seize it"), no substitution with a changeling child is made here (Jón Árnason 1862: 42-43 and 43-44 respectively).

Despite the cautiousness with which the translators operated, carefully selecting and/or adapting the motifs of the fées to fit the Scandinavian worldview of their audience evidently worked as the tropes that were kept clearly clung on in local tradition. The creating of garments has already been addressed above and it thus may suffice to mention the Icelandic account of "Sýslumannskonan á Bustarfelli", as just one of the numerous folktales which depict álfkonur (or huldukonur) as having particular weaving or embroidery skills (motif number F271.4.2) (Thompson 1975: 53), ${ }^{41}$ this account telling of a beautifully crafted altar cloth which is obtained by the woman from a huldukona (Jón Árnason 1862: 13-15). ${ }^{42}$ The fact that stories of the "fairy-folk" being skilful tailors has roots elsewhere is nonetheless reflected in the way stories of this kind have certainly lived on in Celtic-speaking areas. In Scotland,

\footnotetext{
${ }^{39}$ For information regarding the motif of bjergtagning, see, for example, the work by the Danish folklorist Feilberg (1910).

${ }^{40}$ For the changeling in general, see the publication by Christiansen (1958: 109-113). With regard to the motif in France (see above), see, once again, the work by Sébillot (1882: 117-119). For the motif in the British Isles, see, for example, the articles by Katharine M. Briggs (1957: 274-5) and Donald Archie MacDonald (1994/1995: 51-52 [here listed under type numbers F61-66]). For Ireland, see the above-quoted article by Mac Philib (1991). With regard to Sweden, see the monograph by Bengt af Klintberg (2010: 192-197 [here grouped under types K141-169]).

${ }^{41}$ Another narrative that mentions how an altar cloth is donated to a church by an álfkona is "Rauðhöfði" (Jón Árnason 1862: 83-84).

${ }^{42}$ Interestingly, Pjóðminjasafn Íslands (The National Museum of Iceland) has an altar cloth on display which is said to be the cloth from the folktale: see http://www.culturehouse.is/vefleidsogn/inn/room-iii/alfkonudukur-fra-bustarfelli-en.
} 
various narratives describe fairy women working a spinning wheel, giving help with spinning, doing "wool work" or waulking, which have been collected under the Scottish type number F118 "Fairies Help With Clothworking" by MacDonald (1994/1995: 76). In Ireland, meanwhile, similar stories involving the common motif F343.5.1 "Fairy Gives Magic Cloak (And Shirt)" have been noted by Cross (1952: 261). This motif is nonetheless less common in the Nordic countries.

Another connection which seems to have quickly caught on was that of the connections to rocks and underground dwellings, something that can be seen from the earlier-mentioned Qrvar-Odds saga for instance. This the saga tells of how Oddr finds an underground dwelling place of four women, the most beautiful of which he intends to take hostage. This woman, however, promises him to craft him a shirt, the magical properties of which include the feature that the wearer feels no hunger or cold and is invulnerable to sword blows except when in flight (Fornaldarsögur Norðurlanda 1944: 313-14). The parallels to the translated accounts noted above are striking.

Other sagas, such as two fourteenth-century indigenous riddarasogur Hektors saga and Vilmundar saga vidutan play on exactly the same idea. In Hektors saga, a knight by the name of Trancival meets an álfkona living in a hillock and saves her abducted son. In return, Trancival receives a beautiful armoured horse in reward as well as the promise that he will receive any information he desires from the álfkona. The same álfkona and her skills are referred to later in the same saga when Ector recalls her divination abilities (Late Medieval Icelandic Romances 1962: 107110, 124-126, 131 and 170). Vilmundar saga viðutan, meanwhile, notes how Vilmundr's future wife Sóley is given to a foster-mother and her daughter who live in a stone to be educated. These women then give the saga protagonists foreknowledge of various events so that they can react accordingly (Late Medieval Icelandic Romances 1964: 153-155, 162, 182-184 and 194-197). There is little question that the foreign concept of the underground weaving and prophesying álfkonur had become a literary tradition. Since such works were read out aloud alongside other stories in the so-called kvöldvökur ('Evening Wakes') one can understand how the translated foreign material would have impacted upon local oral tradition (Elís saga with its more than 40 surviving manuscripts underlines both the popularity and influence of some of these translated works) (Hermann Pálsson 1962: 14-15, 19 and 39-47; Magnús Gíslason 1977: 57-60 and 77-87). While Einar Ól. Sveinsson, in his Um íslenzkar bjóđsögur, sees 
the most influence on folk tradition as having arisen from the indigenous riddarasogur (Einar Ól. Sveinsson 1940: 157-158 and 2003: 80), the probability is that one needs to go back even further, considering where the writers of the indigenous sagas got their ideas and concepts from. Certainly, some aspects of the fées were dropped or altered by Old Norse translators, as has been highlighted above. Others, however, lived on. This applies particularly to the álfkonur, as one can see from their process from the translated and indigenous riddarasogur. However, their most prominent association of creating beautiful cloths would be taken further in the local tradition. It would not be long before they were not only stealing children (see above), and issuing curses (as in "Álfkonan í Skollholt" or "Álfkonan í Múla") and spinning (for example, "Álfarnir og Helga bóndadóttir" and "Ingibjörg á Svelgsá og álfkonan”), but also entrancing young males (as in, for instance, "Frá Eyjólfi og álfkonu” and "Sagan af Álfa-Árna"), giving birth to children (for example, "Stapaálfarnir" and "Álfkona í barnsnauð”), washing clothes (for example "Álfkonan og áfaaskurinn") and asking for milk (for instance, "Álfkonan pakkláta" or "Borghildur álfkona"); in short, all the "archetypical" roles one might expect of powerful, supernatural women (Jón Árnason 1862: 7-9, 15-16, 34-37, 82-83, 93-100 and 120-123; Einar Guðmundsson 1981: 26-27). ${ }^{43}$

As noted above, the introduction of álfkonur may well hint at changes that were already beginning to take place both in mythological and folk traditions, suggesting that Old Norse mythology and folk belief - in a land that had a multi-cultural background - were seen as being comparatively malleable, ideas coming in and fading out in accordance with needs, new ideas or regional preferences.

\section{Acknowledgements}

This research project has been funded by the Rannsóknasjóður Háskóla Íslands / The Doctoral Grant of the University of Iceland Research Fund, without which this project could not have been successfully concluded. I

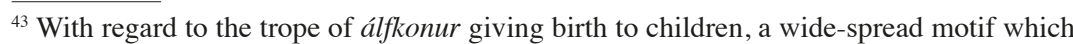
is catalogued under the signature ML 5070 "Midwife To The Fairies" (Almqvist 2008: 273-322; Mac Cárthaigh 1991: 133-143).
} 
want to express my sincere gratitude to my research supervisors Professor Terry Gunnell (Háskóli Íslands), Professor Rudolf Simek (Rheinische Friedrich-Wilhelms-Universität Bonn) and Professor Sif Ríkharðsdóttir (Háskóli Íslands) for their continuous assistance, helpful advice and support in keeping the progress of this project on schedule. Furthermore, I would like to thank Professor Laurent Fournier (Aix-Marseille Université) who provided me with valuable information regarding French folklore. Finally, I wish to thank the helpful staff of the School of Scottish Studies Archives / Tasglann Sgoil Eòlais na h-Alba (University of Edinburgh) for valuable assistance in the field of Scottish folklore.

\section{Bibliography}

In accordance with Icelandic custom, Icelandic names are given in full and are ordered according to the first given name.

Aðalheiður Guðmundsdóttir, 2017: Behind the Cloak, Between the Lines: Trolls and the Symbolism of their Clothing in Old Norse Tradition. European Journal of Scandinavian Studies 47. Pp. 327-350.

Aldhelmi Opera. Ed. by. Rudolf Ehwald. 1919. Berlin. (Monvmenta Germaniae Historica Auctores antiquissimi 15.)

Almqvist, Bo, 1965: Norrön Niddiktning: Traditionshistoriska studier i versmagi. Vol. 1, Nid mot furstar. Uppsala. (Nordiska Texter och undersökningar 21.)

Almqvist, Bo, 2008: Midwife to the Fairies (ML 5070) in Icelandic Tradition. In: Legends and Landscape: Articles based on Plenary Papers Presented at the $5^{\text {th }}$ Celtic-Nordic-Baltic Folklore Symposium, Reykjavík 2005. Ed. by T. Gunnell. Reykjavík. Pp. 273-322.

Anglo-Saxon Remedies, Charms, and Prayers from British Library MS Harley 585: The Lacnunga, Vol. I: Introduction, Text, Translation, and Appendices. Ed. by Edward Pettit. 2001. Lewiston. (Mellen Critical Editions and Translations 6a.)

Ármann Jakobsson, 2015: Beware of the Elf! A Note on the Evolving Meaning of Álfar. Folklore 126. Pp. 215-223.

Arngrímur Sigurðsson, 1980: Íslenzk-ensk orðabók / Icelandic-English Dictionary. Reykjavík.

Briggs, Katharine M., 1957: The English Fairies. Folklore 68. Pp. 270-287.

Briggs, Katharine M., 1969: The Fairies in English Tradition and Literature. Chicago.

Briggs, Katharine M., 1978: The Vanishing People: A Study of Traditional Fairy Beliefs. London. 
Brügger Budal, Ingvil, 2014: The Genesis of Strengleikar: Scribes, Translators, and Place of Origin. In: Eddic, Skaldic, and Beyond: Poetic Variety in Medieval Iceland and Norway. Ed. by M. Chase. New York. Pp. 31-43.

Cameron, M. L., 1993: Anglo-Saxon Medicine. Cambridge. (Cambridge Studies in Anglo-Saxon England 7.)

Chambers, Frank M., 2009: Princeton Encyclopedia of Poetry and Poetics, s.v. "Pastourelle." Princeton.

Chrétien de Troyes: Erec and Enide. Ed. by Burton Raffel. 1997. New Haven/ London.

Christiansen, Reidar Th., 1958: The Migratory Legends: A Proposed List of Types with a Systematic Catalogue of the Norwegian Variants. Helsinki. (FF Communications 175.)

Cross, Tom Peete, 1952: Motif-Index of Early Irish Literature. Bloomington. (Indiana University Publications Folklore Series 7.)

Der festländische Bueve de Hantone Fassung I: Nach allen Handschriften mit Einleitung, Anmerkungen und Glossar. Ed. by Albert Stimming. 1911. Dresden. (Gesellschaft für Romanische Literatur 25.)

Die Lais der Marie de France. Ed. by Karl Warnke. 1925. Halle a. S. (Bibliotheca Normannica 3.)

Düwel, Klaus, 2001: Mittelalterliche Amulette aus Holz und Blei mit lateinischen und runischen Inschriften. In: Ausgrabungen in Schleswig. Vol. 2, Das archäologische Fundmaterial: Lederfunde, Seidenfunde, Münzfunde. Ed. by V. Vogel. Neumünster. (Berichte und Studien 15.) Pp. 227-302.

Eddukvæði. Ed. by Jónas Kristjánsson and Vésteinn Ólason. 2 vols. 2014. Reykjavík.

Egils saga Skallagrímssonar: A-Redaktionen. Ed. by Bjarni Einarson efter forarbejder af Jón Helgason. 2001. København. (Editiones Arnamagnæanæ Series A, 19.)

Einar Guðmundsson, 1981-1982: Pjóðsögur og pættir. 2 vols. Hafnarfjörður.

Einar Ól. Sveinsson, 1940: Um íslenzkar pjóđsögur. Reykjavík.

Einar Ól. Sveinsson, 2003: The Folk-Stories of Iceland. Rev. by E. G. Pétursson. Ed. by A. Faulkes. Trans. by B. S. Benedikz. Exeter. (Viking Society for Northern Research Text Series 16.)

Élie de Saint-Gille. Ed. by Bernard Guidot. 2013. Paris. (Classiques français du Moyen Âge 171.)

Elis saga ok Rosamundu. Ed. by Eugen Kölbing. 1881. Heilbronn.

Elye of Saint-Gilles: A Chanson de Geste. Ed. by A. Richard Hartmann and Sandra C. Malicote. 2001. New York.

Feilberg, Henning F., 1910: Bjærgtagen: Studie over en gruppe fra nordisk alfetro. København. (Danmarks Folkeminder 5.)

Ferro, Marc, 2001: Histoire de France. Paris.

Finnur Jónsson, 1973: Den norsk-islandske skjaldedigtning. Vol. 2, Rettet Tekst. 2 vols. København. 
Fornaldarsögur Norðurlanda. Ed. by Guðni Jónsson and Bjarni Vilhjálmsson. 3 vols. 1944. Reykjavík.

Gallais, Pierre, 1992: La Fée à la Fontaine et à l'Arbre: Un Archetype du Conte Merveilleux et du Récrit Courtois. Amsterdam/Atlanta. (Centre d'Etudes et de Recherches sur le Merveilleux, l'Etrange et l'Irréel en Littérature 1.)

Goffredo di Auxerre: Super Apocalypsim. Ed. by Ferruccio Gastaldelli. 1970. Roma. (Temi e Testi a Cura di Eugenio Massa 17.)

Gretsch, Mechthild, 1999: The Intellectual Foundations of the English Benedictine Reform. Cambridge. (Cambridge Studies in Anglo-Saxon England 25.)

Grimm, Wilhelm, and Jacob Grimm, 1812: Kinder- und Hausmärchen. Berlin.

Gunnell, Terry, 2007: How Elvish are the Álfar? In: Constructing Nations, Reconstructing Myth: Essays in Honour of T. A. Shippey. Ed. by A. Wawn, G. Johnson \& J. Walter. Turnhout. Pp. 111-130.

Gunnell, Terry, 2012: National Folklore, National Drama and the Creation of Visual National Identity: The Case of Jón Árnason, Sigurður Guðmundsson and Indriði Einarsson in Iceland. In: Folklore and Nationalism in Europe During the Long Nineteenth Century, edited by T. Baycroft and D. Hopkin. Leiden/Boston. Pp. 301-323.

Gunnell, Terry, 2014: Modern Legends in Iceland. In: Narratives Across Space and Time: Transmissions and Adaptations: Proceedings from the $15^{\text {th }}$ Congress of the International Society for Folk Narrative Research (June 21-27, 2009 Athens). Ed. by A. Polymerou-Kamilaki, E. Karamanes \& I. Plemmenos. 3 vols. Athens. (Publications of the Hellenic Folklore Research Centre 31.) Pp.337-352.

Gunnell, Terry, 2018: The Álfar, the Clerics and the Enlightenment: Conceptions of the Supernatural in the Age of Reason in Iceland. In: Fairies, Demons, and Nature Spirits: 'Small Gods' at the Margins of Christendom. Ed. by M. Ostling. London. Pp. 191-212.

Hall, Alaric, 2005: Getting Shot of Elves: Healing, Witchcraft and Fairies in the Scottish Witchcraft Trials. Folklore 116. Pp. 19-36.

Hall, Alaric, 2007: Elves in Anglo-Saxon England: Matters of Belief, Health, Gender and Identity. Woodbridge. (Anglo-Saxon Studies 8.)

Harf-Lancner, Laurence, 1984: Les Fées au Moyen Âge: Morgane et Mélusine: La Naissance des Fées. Genève. (Nouvelle Bibliothèque du Moyen Âge 8.)

Harf-Lancner, Laurence, 2003: Le Monde des Fées dans l'Occident Médiéval. Paris.

Hauksbók: Udgiven efter de Arnamagnæanske Håndskrifter no. 371, 544 og 675, $4^{\circ}$. Ed. by Eiríkur Jónsson and Finnur Jónsson,. 1896. København.

Haukur Porgeirsson, 2011: Álfar í gömlum kveðskap. Són 9. Pp. 49-61.

Hermann Pálsson, 1962. Sagnaskemmtun Íslendinga. Reykjavík.

Holtsmark, Anne, 1964: Studier i Snorres mytologi. Oslo. (Skrifter utgitt av Det norske videnskaps-akademi i Oslo, II Hist.-filos. klasse, ny serie 4.)

Honko, Lauri, 1959: Krankheitsprojektile: Untersuchung über eine urtümliche Krankheitserklärung. Helsinki. (FF Communications 178.) 
Isidori Hispalensis Episcopi Etymologiarum Sive Originum Libri XX. Ed. by. W. M. Lindsay. 1911. Oxford.

Íslendingabók, Landnámabók. Ed. by Jakob Benediktsson. 1968. Reykjavík. (Íslenzk fornrit 1.)

Jón Árnason, 1862-1864: Íslenzkar pjóđsögur og æfintýri. 2 vols. Leipzig.

Jón Hnefill Aðalsteinsson, 1991: Under the Cloak: A Pagan Ritual Turning Point in the Conversion of Iceland. Reykjavík.

Jorgensen, Peter, 1999: Tristrams saga ok Ísöndar. In: Norse Romance, Vol. 1, The Tristan Legend. Ed. by M. E. Kalinke. Cambridge. (Arthurian Archives 3). Pp. 23-226.

Kalinke, Marianne E., 1979: Gvímars saga. Opuscula 7. Pp. 106-139.

Kalinke, Marianne E., 1999: Erex saga. In: Norse Romance. Vol. 2, The Knights of the Round Table. Ed. by M.E. Kalinke. Cambridge. (Arthurian Archives 4). Pp. 217-265.

Kalinke, Marianne E., 1999: Mọttuls saga. In: Norse Romance. Vol. 2, The Knights of the Round Table. Ed. by M. E. Kalinke. Cambridge. (Arthurian Archives 4). Pp. 1-36.

Klintberg, Bengt af, 2010: The Types of the Swedish Folk Legend. Helsinki. (FF Communications 300.)

Lazamon's Brut or Chronicle of Britain: A Poetical Semi-Saxon Paraphrase of the Brut of Wace. Ed. by Frederic Madden. 3 vols. 1847. London.

Late Medieval Icelandic Romances. Vol. 1, Victors saga ok Blávus, Valdimars saga, Ectors saga. Ed. by Agnete Loth. 1962. Copenhagen. (Editiones Arnamagnæanæ Series B 20.)

Late Medieval Icelandic Romances. Vol. 4, Vilhjálms saga sjóðs, Vilmundar saga viðutan. Ed. by Agnete Loth. 1964. Copenhagen (Editiones Arnamagnæanæ Series B 23.)

Lecouteux, Claude, 1988: Les Nains et les Elfes au Moyen Ages. Paris.

Lecouteux, Claude, 1992: Fées, Sorcières et Loup-Garous au Moyen Âge. Paris.

Les Romans de Chrétien de Troyes édités d'après la copie de Guiot (Bibl. nat., fr. 794), Vol. 1, Erec et Enide. Ed. by Mario Roques. 1968. Paris.

Lindow, John, 2008: Changelings, Changing, Re-Exchanges: Thoughts on the Relationship between Folk Belief and Legend. In: Legends and Landscape: Articles Based on Plenary Papers Presented at the $5^{\text {th }}$ Celtic-Nordic-Baltic Folklore Symposium, Reykjavík 2005. Ed. by T. Gunnell. Reykjavík. Pp. 215-234.

Loomis, Roger Sherman, 1959: Layamon's Brut. In: Arthurian Literature in the Middle Ages: A Collaborative History. Ed. by R. S. Loomis. Oxford. Pp. 104 111.

Lord, Albert B., 1981: The Singer of Tales. Cambridge, MA/London. (Harvard Studies in Comparative Literature 24.)

Mac Cárthaigh, Críostóir, 1991: Midwife To The Fairies (ML 5070): The Irish Variants in Their Scottish and Scandinavian Perspective. Béaloideas 59. Pp. 133-143. 
Mac Philib, Séamas, 1991: The Changeling (ML 5085): Irish Versions of a Migratory Legend in Their International Context. In: The Fairy Hill is on Fire!: Proceedings of the Symposium on the Supernatural in Irish and Scottish Migratory Legends, Dublin 8 October 1988. Ed. by P. Ó Héalaí. Béaloideas 59. Pp. 121-131.

MacDonald, Donald Archie, 1994/1995: Migratory Legends of the Supernatural in Scotland: A General Survey. Béaloideas 62/63. Pp. 29-78.

Magnús Gíslason, 1977: Kvällsvaka: En isländsk kulturtradition belyst genom studier i bondebefolkningens vardagsliv och miljö under senare hälften av 1800-talet och början av 1900-talet. Uppsala. (Studia Ethnologica Upsaliensia 2.)

Martianus Capella: Accedunt Scholia in Caesaris Germanici Aratea. Ed. by Franz Eyssenhardt. 1866. Leipzig.

Motz, Lotte, 1973/1974: Of Elves and Dwarfs. Arv 29/30. Pp. 93-127.

Padberg, Lutz E von, 2009: Die Christianisierung Europas im Mittelalter. Stuttgart. (Reclams Universal-Bibliothek 18641.)

Perrault, Charles: Contes. Ed. by Tony Gheeraert. 2012. Paris. (Champion Classiques Littératures 20.)

Peters, R. A., 1963: OE Ælf, -Ælf, Ælfen, -Ælfen. Philological Quarterly 42. Pp. 250-257.

Pokorny, Julius, 1959: Indogermanisches Etymologisches Wörterbuch. 3 vols. Bern/München.

Reichborn-Kjennerud, Ingjald, 1928: Vår gamle trolldomsmedisin. 5 vols. Oslo. (Skrifter utgitt av Det Norske Videnskaps-Akademi i Oslo II. Hist.-Filos. Klasse 1927, 6-11.)

Saintyves, Pierre, 1936: Manuel de Folklore. Paris.

Samsons saga fagra. Ed. by John Wilson. 1953. Copenhagen. (Samfund til Udgivelse af Gammel Nordisk Litteratur 65(1).)

Schoon Eberly, Susan, 1988: Fairies and the Folklore of Disability: Changelings, Hybrids and the Solitary Fairy. Folklore 99. Pp. 58-77.

Schück, Henrik, 1941: Odin, Vili och Vé. Fornvännen 36. Pp. 22-29.

Sébillot, Paul, 1882: Traditions et Superstitions de la Haute-Bretagne. Paris.

Sébillot, Paul, 1905: Le Folk-lore de France. Vol. 2: La Mer et les Eaux Douces. Paris.

Shippey, Tom, 2005: Alias Oves Habeo: The Elves as a Category Problem. In: The Shadow-Walkers: Jacob Grimm's Mythology of the Monstrous. Ed. by T. Shippey. Tempe. (Medieval and Renaissance Texts and Studies 291 / Arizona Studies in the Middle Ages and the Renaissance 14.) Pp. 157-187.

Sienaert, Edgard, 1984: Les Lais de Marie de France: Du Conte Merveilleux à la Nouvelle Psychologique. Paris. (Collection ESSAIS 2.)

Sif Ríkharðsdóttir and Stefka G. Eriksen, 2013: État present: Arthurian Literature in the North. Journal of the International Arthurian Society 1. Pp. 3-28.

Simek, Rudolf, 2011a: The Late Roman Iron Age Cult of the matronae and Related Germanic Deities. In: Weibliche Eliten in der Frühgeschichte: 
Internationale Tagung vom 13. bis zum 14. Juni 2008 im RGZM im Rahmen des Forschungsschwerpunktes "Eliten". Ed. by D. Quast. Main. (RGZM Tagungen 10.). Pp. 219-227.

Simek, Rudolf, 2011b: Elves and Exorcism: Runic and Other Lead Amulets in Medieval Popular Religion. In: Myths, Legends and Heroes: Essays on Old Norse and Old English Literature in Honour of John McKinnell. Ed. by Daniel Anlezark. Toronto. Pp. 25-52.

Simek, Rudolf, 2013: Álfar and Demons, or: What in Germanic Religion Caused the Medieval Christian Belief in Demons? In: Conversions: Looking for Ideological Change in the Early Middle Ages. Ed. by L. Słupecki and R. Simek, Wien. (Studia Medievalia Septentrionalia 23.) Pp. 321-341.

Simek, Rudolf, 2017a: On Elves. In: Theorizing Old Norse Myth. Ed. by S. Brink and L. Collinson. Turnhout. (Acta Scandinavica 7.) Pp. 195-223.

Simek, Rudolf, 2017b: Demons at Work: The Machinations of Demons in Scandinavian History of the Early Middle Ages. In: Materialy v Kongresu mediewistów Polskich / Proceedings of the $5^{\text {th }}$ Congress of Polish Medievalists. Ed. by L. Słupecki \& al. Rzeszów. Pp. 135-151.

Simek, Rudolf, 2019: Tangible Religion: Amulets, Illnesses, and the Demonic Seven Sisters. In: Myth, Materiality, and Lived Religion. Ed. by Klas Wikström af Edholm et. al. Stockholm. (Stockholm Studies in Comparative Religion 40). Pp. 375-395. (DOI: https://doi.org/10.16993/bay).

Snorri Sturluson: Prologue and Gylfaginning. Ed. by Anthony Faulkes. 2005. London.

Snorri Sturluson: Skáldskaparmál. Ed. by Anthony Faulkes. 2 vols. 1998. London.

Strengleikar eða Lioðabok: En Samling af Romantiske Fortællinger efter Bretoniske Folkesange (Lais). Ed. by. Rudolph Keyser and Carl Richard Unger. 1850. Christiania.

The Anglo-Saxon Poetic Records. Vol. 1, The Junius Manuscript. Ed. by George Philip Krapp. 1931. New York.

The Anglo-Saxon Poetic Records. Vol. 4, Beowulf and Judith. Ed. by Elliott van Kirk Dobbie. 1965. New York.

The Lais of Marie de France. Trans. by Robert Hanning and Joan Ferrante. 2009. Grand Rapids.

The Lay of Mantel. Ed. by Glyn S. Burgess and Leslie C. Brook. 2013. Cambridge. (French Arthurian Literature V / Arthurian Archives 18.)

The Old Norse Elucidarius. Ed. by Evelyn Scherabon Firchow. 1992. Columbia. The Poetic Edda. Trans. by Carolyne Larrington. 1996. Oxford/New York.

Thompson, Stith, 1975: Motif-Index of Folk-Literature: A Classification of Narrative Elements in Folktales, Ballads, Myths, Fables, Mediaeval Romances, Exempla, Fabliaux, Jest-Books, and Local Legends. Vol. 3, F-H. Bloomington/ London.

Vatnsdœla saga, Hallfreðar saga, Kormáks saga, Hrómundar páttr halta, Hrafns páttr Guðríðarsonar. Ed. by Einar Ól. Sveinsson. 1939. Reykjavík. (Íslenzk fornrit 8.) 
Vries, Jan de, 1956: Altgermanische Religionsgeschichte. 2 vols. Berlin.

Wagner, Norbert, 1980: Zur Neunzahl vin Lejre und Uppsala. Zeitschrift für deutsches Altertum 109. Pp. 202-208.

Walter, Philippe, 1992: Mythologie Chrétienne: Rites et Mythes du Moyen Age. Paris.

Williams, Noel, 1991: The Semantics of the Word Fairy: Making Meaning Out of Thin Air. In: The Good People: New Fairylore Essays. Ed. by P. Narváez. New York/London. Pp. 457-478.

\section{Online References (last viewed 12.04.2021)}

https://skaldic.abdn.ac.uk/db.php. http://www.bl.uk/manuscripts/FullDisplay.aspx?ref=Harley_MS_585.

http://www.culturehouse.is/vefleidsogn/inn/room-iii/alfkonudukur-frabustarfelli-en.

https://archivesetmanuscrits.bnf.fr/ark:/12148/cc71766w.

https://onp.ku.dk/onp/.

\section{Summary}

This paper forms part of a doctoral thesis in Old Nordic Religions at the University of Iceland, which seeks to examine the use of Nordic supernatural concepts (such as jotnar, dvergar and álfar) in the Old Nordic translations of Old French, Occitan and Anglo-Norman chivalric and courtly romances and lais in the twelfth to fourteenth centuries. This present article focuses on the use of the word "álfar" as a translation for the French word "fées", considering not only the narrative purposes involved in the choice of such a word, but the potential influences on Icelandic folk beliefs that might have been caused by such a translation (as these translation were read out alongside more local narratives).

Keywords: Old Nordic Religion, álfar, translated riddarasogur, Folklore, Translation Studies

Felix Lummer

University of Iceland

Faculty of Sociology, Anthropology and Folkloristics

ORCID iD 0000-0002-6867-8921 


\section{Preserving Blunders in Eddic Poems Formula Variation in Numbered Inventories of Vafbrúðnismál and Grímnismál}

FROG

\section{Introduction}

Eddic $^{1}$ poetry exhibits what I have described as an inclination to non-variation in its use of phraseology (Frog 2011: 58-72; 2021). In other words, at least narrative poetry seems to have been characterized by ideals of performing formulae and passages 'the same' each time where repetition is salient. When the inclination to non-variation is recognized, formulaic phraseology that seems to vary when 'saying the same thing' raises a flag against the backdrop of the corpus. Non-variation appears as a general ideal, which leads variations that may initially seem incidental to stand out as sites of interest. If such variations are attributable to the person who wrote or dictated the text, they may offer illustrations of the dynamism of the tradition and the operation of creative agency within it. ${ }^{2}$ Conversely, a variation may reflect non-ideal phrasing or otherwise reflect processes through which the written text was produced.

\footnotetext{
${ }^{1}$ I would like to thank Gísli Sigurðsson for his extremely valuable and detailed comments and criticisms, which have greatly improved this study.

${ }^{2}$ Formula variation in Grípisspá points to a valorization of variation in phraseology (e.g. Mellor 1999 [2008]: 122). For present purposes, it is irrelevant whether the poem was composed in writing: it reflects knowledge of the poetic form and language and attitudes toward them. The point here is simply that individuals may engage with a tradition in ways that deviate considerably from social conventions (e.g. Harvilahti 1992b: 95-96).
}

Frog. 2021. Preserving Blunders in Eddic Poems: Formula Variation in Numbered Inventories of Vafprúðnismál and Grímnismál.

Scripta Islandica 72: 43-91.

(C) Frog (CC BY)

DOI: $10.33063 /$ diva-439401 
This is an exploratory study that examines formula variation in connection with the numbered inventory of questions posed by Óðinn to Vafprúðnir in Vafprúðnismál and the numbered inventory of locations in Grímnismál. Several numbered inventories are preserved in the corpus, so variation in these two poems can be considered in relation to other commensurate lists. Whereas a single variation in isolation remains ambiguous, both poems exhibit multiple co-occurring features that appear non-ideal. In Vafprúðnismál, one variation produces a long line that lacks alliteration, and a second seems to forego the repetition of lines opening a question and either the question and answer are only half their usual length or only one rather than two turns of dialogue is presented. In Grímnismál, different formulae are used for numbering locations, and this co-occurs with a mix-matching of numbering, identifying the fourth named location as the 'third', along with several additional variations concentrated in the first three stanza-like passages of the list. In each case, variations are assessed in terms of whether they more likely originate from the copying process or from the initial documentation of the respective poem or section of a poem, and what this may suggest about processes in the background.

Like so much in eddic poetry research, the assessments are inevitably interpretations, and thus are considered probabilities of varying degrees of likelihood. Some of these are interdependent, some are reciprocally reinforcing or mutually exclusive, and most are unavoidably contingent on interpretations of some feature of the text being non-ideal. The exploratory nature of this investigation advances into areas where the source materials have not previously been interrogated with the questions considered here. Consequently, more deliberation on alternative explanations and false tracks is required in the main text or in notes than in a study concerned with a more familiar issue where frameworks are established for how to interpret types of evidence or it is possible to lean on findings of earlier studies. After both cases have been examined, discussion turns to the question of why the documented poems would retain lines and passages where something seems to have gone wrong when it was first formulated - i.e. why 'blunders' were not corrected - and what this suggests about how people conceived the written poems, with implications for their use as sources in research. 


\section{Sources and methodology}

\subsection{An inclination to non-variation}

Oral eddic poems are here approached as socially recognizable 'things' made of language and their reproduction is considered characterized by ideals of non-variation. ${ }^{3}$ Oral-Formulaic Theory (OFT) has become a dominant model for approaching how oral poetry varies. 'Classic' OFT - i.e. OFT as formalized by Albert Lord in 1960 - presents a compositionin-performance model for long epic traditions, whereby stories are retold freely in the traditional idiom in each performance. Although this model has been considered for eddic poetry, the corpus does not present evidence to suggest that eddic poems were verbally composed anew in each performance. Eddic poems differ from epic traditions even in other Germanic languages by being much shorter in length, composed in relatively tight sequences of long lines ${ }^{4}$ commonly described as 'strophes', and lacking evidence of a formulaic infrastructure suggestive of a composition-in-performance tradition. ${ }^{5}$ Passages of poems are quoted, for example in Snorri Sturluson's Edda, in ways that imply they were socially recognizable and recognizable as identified with a particular poem as opposed to others, not unlike skaldic poetry. This is consistent with the shorter form of individual poems and their composition in units forming series of verses. In such traditions, groups of verses that are regularly reproduced tend to 'crystallize' in individuals' memories and circulate as verbal units of composition, and whole poems and their parts become rememberable as constituted of these units. This does not mean that the units are invariable, only that they are not being composed on a formula-by-formula and line-by-line basis. Stability in oral transmission

\footnotetext{
${ }^{3}$ On oral poems as 'things' made of language, see Frog 2019; concerning eddic poems, see Frog 2021.

${ }^{4}$ Other Old Germanic poetries allow a clause continued from the preceding long line to conclude in the first short line and then an independent clause to begin following the causura to continue onto the next long line. Eddic syntax generally does not allow an independent clause to begin within a long line unless one or both clauses are only a short line in length.

${ }^{5}$ See also Lönnroth 1971; Mellor 1999; Haymes 2003; Thorvaldsen 2006. Gísli Sigurðsson (1998: xx) proposes that poems were composed anew in each performance and then shifted toward a more memorized tradition through impacts of literacy and the Church, but the analogous case of Old English poetry (e.g. Amodio 2004) does not support this view and the formal changes in the poetic system seem to have come centuries earlier.
} 
is, however, not simply an outcome of poetic form: it is rooted in social convention. ${ }^{6}$

Dominant ideals of non-variation in eddic poetry can be observed in both the social stability of phraseology in independent, oral-derived ${ }^{7}$ vari- $^{-}$ ants of the same passage of text and also in formula repetition within a particular text. ${ }^{8}$ Narrowing focus to within a version of a text points to how individuals reproduced those texts. When focus is on formula variation, comparison across versions of poems will present differences between the ways two or more individuals performed them, clouding tendencies of individuals with what can be described as 'dialects' of performance. For example, the preserved poem Alvíssmál is particularly interesting with regard to formula variation because the dwarf's thirteen answers to Pórr's questions are consistently comprised of six formulae, each with an open slot completed by a word or phrase specific to the question, and which formula is used is driven by alliteration with the slot-fillers in a-lines and Vollzeilen (Acker 1983: ch.3; 1998: ch.3; Thorvaldsen 2006: 116-117; Frog 2011). Within the poem, even superficial variations in the phraseology of repeated formulae generally seem to be avoided, and those that occur are at the particular formula's first use (Frog 2011: 58-72). Two passages of the poem are quoted in Snorra Edda: the twelve uses of formulae exhibit seven variations (Frog 2021:\$6). Ideals of non-variation are obvious within the poem Alvíssmál ${ }^{9}$ owing to the number of formula repetitions, whereas if only comparisons between corresponding passages

\footnotetext{
${ }^{6}$ Thus, most regions of kalevalaic epic exhibit a high degree of verbal regularity (Frog 2016); in a southern region where epic shifted into a women's singing tradition and converged with other narrative genres in the same meter, it become far more flexibly handled (Harvilahti 1992a), whereas lyric poetry in the same meter remained extremely dynamic even where epic remained more conservative (Timonen 2004). North Russian bylina-epics are formally comparable in length and content to eddic narrative poetry and kalevalaic epic but appear quite flexible in performance, characterized by passages that remained verbally regular while their organization and the connecting tissue between them varied (Gil'ferding 1894: 24). Consequently, bylina-epics open to analysis through Classic OFT (e.g. Arant 1990) in a way that it is not readily applicable to eddic poems.

${ }^{7}$ On the concept of 'oral-derived' text, see Foley 1990.

${ }^{8}$ I initially argued this with focus on Alvíssmál (Frog 2011); for a more recent study, see Frog 2021.

${ }^{9}$ All references to passages within preserved poems are thus made using abbreviations: Alv = Alvíssmál, $B d r=$ Baldrs draumar, $F m=$ Fáfnismál, $G ð r I=$ Gudrúnarkviða $I, G m$ = Grímnismál, Háv = Hávamál, HH I = Helgakviða Hundingsbana I, HH II = Helgakviða Hundingsbana II, Hym = Hymiskviða, Sd = Sigrdrífumál, Skm = Skírnismál, Vm = Vafprúðnismál, $V s p=$ Vǫluspá, $P k v=$ Prymskviða; passages are numbered following the Neckel \& Kuhn edition (1963), with line numbers following a period when relevant, so Vm
} 
in Snorra Edda are in focus, the use of formulae appears more flexible. Not all performers necessarily engaged with the tradition according to ideals of non-variation (cf. Harvilahti 1992b: 95-96), and Alvíssmál may get closer to ideals of non-variation than some other poems, yet the corpus generally appears characterized by non-variation in repetition as an ideal.

The theory of the inclination to non-variation has been developed especially through the analysis of poems on mythological subjects, with which Grímnismál and Vafprúðnismál are grouped. The same principles also seem attributable to poems on heroic subjects, although these generally have less text-internal repetition to assess. ${ }^{10}$ The degree of verbal correspondence between independently documented texts of the same poems is a fact of the corpus that generally gets taken for granted in eddic scholarship. Nineteenth-century researchers started off imagining the poems through modern, literary poetry and envisioning the oral transmission of poems through their medieval manuscript transmission. These combined frames of reference provided the initial lens for interpreting the degree of sameness between the Codex Regius' and Hauksbók's Voluspás or between Snorra Edda's numerous eddic quotations and independent poems. The variations were often so minimal that they were easily interpreted through that lens - a difference of a word or two within a phrase; the presence, absence or arrangement of verses or groups of verses. The high degree of phraseological sameness even yielded inter-

40.1-2 indicates the first long line / pair of short lines of the fortieth passage of Vafprúdnismál according to the Neckel \& Kuhn edition.

${ }^{10}$ See e.g. repetitions between $H H$ II 40 and 41, Fm 8 and 20, Fm 12 and 14, Sd below, and Gðr I 5 and 11; see also Lönnroth 1971. Dividing the corpus into mythological and heroic poetry follows the arrangement of the Codex Regius manuscript, which is somewhat arbitrary in that the 'mythological' and 'heroic' poems seem to reflect earlier collections brought together by a copyist (Vésteinn Ólason 2019: 235-242 and works there cited). It may be worth noting that Grímnismál, for instance, concerned with a king and his son rather than with events of cosmological scope, would probably not be considered as a mythological poem if it were found preserved as an episode in a longer saga; alternately, the story of Loki's slaying of Otr would likely be considered mythological if it were only preserved as a separate poem independent of the story of Sigurðr. The number and diversity of heroic poems in the Codex Regius manuscript point to a vibrant oral tradition in the background, but the background of the individual poems is unclear. Any generalization about differences in how poems varied should begin with genre categories, which is more likely than subject matter to indicate use in connection to practices. From this perspective, the monologic and dialogic poems in ljóðaháttr appear different from the third-person narrative poems in fornyrðislag in terms of practice and also idiom (Gunnell 1995: ch. $3-5$ ), and thus more likely to be linked to differences in variation than the grouping of poems in the Codex Regius. 
pretations that every eddic text ultimately traces back to a single manuscript exemplar, and scholars created narratives to account for differences between sources (e.g. Dronke 1997). Viewed against different forms of oral poetry, however, the high degree of sameness points to a tradition that, verbally, was extremely conservative. ${ }^{11}$ It suggests that those learning the poetry aspired to perform it 'the same' as other performers, and the conception of sameness was understood as directly connected to phraseological regularity, so that rephrasing verses and reformulating sequences of verses seems generally to be avoided. ${ }^{12}$

Evidence of independently-attested poems and poetic passages from the mythological corpus generally foreground verbal stability, but the inclination to non-variation did not necessarily apply uniformly to whole texts, although the crystallization of phraseology into verbally regular passages tends to center on units that are semantically or functionally significant. ${ }^{13}$ Snorra Edda may increase impressions of non-variation by predominantly quoting passages where verbal crystallization is expected to be highest, as may the two versions of Voluspá as a poem made up almost entirely of such units. Conversely, verses and passages that receive less semantic weight may be less crystallized or more open to variation in transmission, ${ }^{14}$ like the general comments to Loki opening knowledge about Frigg in Snorra Edda's quotation from Lokasenna (Frog 2021:§6). Similarly, where repetition is salient within a poem, phraseology appears more regular, as in introductions to inventories of mythic knowledge discussed below (cf. also e.g. Skm 17-18, Skm 39, 41, Pkv 26, 28), whereas

${ }^{11}$ In a comparison of passages from Uzbeck and Karakalpak epics, for example, Karl Reichl (1985: 631) observes that "[v]ariants are often phonetically/graphemically so close that they look like reading or aural mistakes."

${ }^{12}$ Parallel passages where verbal correspondences are recognizable but phraseology is markedly different are also found. In poems on mythological subjects, these include, for instance, the descriptions of Pórr's eating in Hym 15 and Pkv 24 and the passages on the revenge cycle surrounding Baldr in the monologue of Vsp 31-34 and the dialogue of $B d r$ 7-11. In the present context, it is relevant to observe that the parallels with marked differences in phraseology are found in different poems rather than being characterized as 'the same' text. Such passages are also found in the heroic poems, noting that a redactor's editing of passages considered 'the same' between HH I and HH II (see Harris 1983 [2008]: 191-202) seems simultaneously to distinguish the poems as 'different'.

${ }^{13}$ Anna-Leena Siikala (1990: 80-86) initially developed the concept of crystallization based on observations of verbal regularity around semantically central units in legends by individual tellers, only later extending the concept to the transmission of oral poetry.

${ }^{14}$ This view is complementary to Lars Lönnroth's (1971: 16) observation that phraseology in Hjálmar's Death Song appears more stable where it is specific to the passage of the poem and more variable where it relies on prefabricated formulaic phraseology. 
minor variations may not have been noticeable in common formulae used only occasionally within a poem (Frog 2021:\$5). The present study focuses on passages where the inclination to non-variation is predicted as a social ideal for a repeating formula or series of lines.

\subsection{Questions of poetic form and the documentation process}

Considerations of orality behind eddic poems has increased considerably since the turn in OFT research from emphasis on form to foreground meanings, ${ }^{15}$ yet such orality continues to be taken for granted (see also Harris 1983 [2008]: 189). Questions of the relationship between the manuscript texts and oral performance have predominantly focused on variation, whether in the oral tradition behind written texts (e.g. Thorvaldsen 2008) or in the interpretation of the written texts as variations from the oral tradition (e.g. Gísli Sigurðsson 1998). The push to return to the manuscript texts rather than relying on edited editions (e.g. Quinn 2016) has nevertheless remained inclined to interpret textual details through the lens of modern literature, reading all details as reflecting meaningful intention. The transition of poems from oral discourse into writing has generally remained invisible. The written poems have consequently tended to be conflated with accurate transcripts of oral performances (if subsequently mediated through scribal transmission), without consideration of how the documentation process may have impacted the text in either presentation or transcription. Although the particular processes remain unknown, the documentation process requires consideration as a factor when considering text variation.

As Gísli Sigurðsson (1998: xx) has stressed, the speed of transcribing an eddic poem would undoubtedly be far slower than the rate of an oral performance and the resulting text should not be confused with an ethnographic transcript of an oral performance. The documentation of poems can be assumed either to have involved a slow, interruptive and potentially frustrating process of dictation or a slow, reflective transcription from personal knowledge and memory. Dictation inevitably impacts on the

\footnotetext{
${ }^{15}$ On this turn, see e.g. Foley \& Ramey 2012; Frog \& Lamb 2021; the use of OFT with an interest in meanings in variation shows up in eddic poetry research at the International Saga Conference in 1988 (Gísli Sigurðsson 1990; Quinn 1990) and began gaining momentum across the 1990s, reinforced by the rising interest in performance (e.g. Gunnell 1995) and publication of Paul Acker's (1998) important study as well as Gísli Sigurðsson’s (1998) introduction to his edition of the poems.
} 
realization of oral poetry, as has been observed and discussed for countless traditions already since the nineteenth century. ${ }^{16}$ The impacts of this process vary by tradition and by the individuals involved, and include both "those skillfully and those ineptly done" (Lord 1960: 149). Dictation may regularize the metrical form by reducing or eliminating the flexibility of a normal performance, or the poetic form may break down entirely, for example because expletive particles relevant to meter but not meaning are omitted, or because the presenter tells what verses would say in paraphrase or simply summarizes content. Transcription from personal knowledge lacks the interactive dimension, and allows the writer to work at his or her own pace with time for deliberation and reflection, potentially resulting in text aligned with the writer's ideals.

Dictation has tended to be imagined as the most probable way for oral poetry to enter writing. ${ }^{17}$ This idea is centrally built on modern collection activity, on the backdrop of an ideology that spread with the Enlightenment and Romanticism and that conferred value on traditions that were historically, religiously and/or culturally 'other'. This ideology prompted outsiders with a literate cultural background to interview oral poets or organize poetry's documentation. Throughout most of the twentieth century, orality and literacy were viewed as opposed and exclusive categories. This made it seem natural that oral poetry must be presented by someone who is illiterate and documented by someone who is literate. The polarized view marginalized poetry written by literate people based on personal knowledge of an oral tradition by not considering it authentically 'oral'. However, orality and literacy can be extremely fluid, as seen in traditions ranging from European ballads to improvizational rap battles (see also Foley 2010). In the Middle Ages, texts were commonly written for oral delivery, creating a milieu characterized by aurality (Coleman 1996). Written texts were also open to potentially considerable variation rather than only being slavishly reproduced ${ }^{18}$ and the Old English poet Cynewulf appears as someone fluent in the oral poetic idiom while his runic signatures indicate he was

\footnotetext{
${ }^{16}$ For a survey of many such accounts with extensive quotations, see Ready 2015: 13-24.

${ }^{17}$ This impression has been augmented by discussion centering around questions about Homeric poetry, so that comparative emphasis has been on long and variable epic forms (e.g. Lord 1960; Ready 2015).

${ }^{18}$ The interactions of orality and literacy have been extensively explored in Old English poetry: e.g. O'Keeffe 1990; Doane 1994; Amodio 2004; on 'scribal performance' generally, see Ready 2019; in Old Norse poetry, see e.g. Harris 1983 [2008]; on Old Norse text variation by copyists, see also Jansson 1944; Sävborg 2012.
} 
writing them himself. It seems eddic poems began being written down within about a century of the development of vernacular writing. The Old Norse corpus is predominantly prose, but that prose is filled with quotations of different types of poetry stemming from the oral tradition. If quotations of poems in sagas are considered written out from personal knowledge, there is no reason to assume a priori that whole eddic poems were transcribed from dictation.

Transcribing the eddic poems indicates that they were valuable and interesting to the people who wrote them, and that they were valued as poems rather than only for informational content. Poems on mythological subjects in particular would have to be sufficiently valorized among people who were literate to invest in the time, trouble and expense to document them in spite of their 'pagan' subject matter. The social gap between peasant oral performers and modern literate collectors would be anachronistic for medieval Iceland, as would the ideology of the Enlightenment and Romanticism. There is no reason to believe that a community of medieval Christians would valorize such 'pagan' poems without viewing them as their own traditions to start with, and no reason think that the literate person documenting poems was a social outsider with little or no advanced knowledge of the tradition. ${ }^{19}$ Writing the poems down suggests a continuity of the oral traditions in the communities doing the writing. Although the exact purpose of the written poems is unknown, writing them out indicates that they were intended to be used, as does collecting and copying them. The texts were produced by and for literate audiences, although their use most likely had a social dimension, connected with public rather than private reading (see also Coleman 1996). The oral delivery of written poems can be assumed to have followed the conventions of the oral performance tradition, so the writing of eddic poems should be viewed as an extension of the oral tradition rather than divorced from it (Mundal 2010: 166-167), even if the oral tradition may have been transformed or gradually displaced as a historical process (see also Gísli Sigurðsson 1998: xx). How different poems were documented may have

\footnotetext{
${ }^{19}$ Romanticism's elevation of non-Christian mythology tends to be seen in terms of heritage and its expression of a 'spirit' of a people, but it is worth noting that this built on ideas of the Enlightenment that saw mythology as inspired and thus as achieving aesthetic ideals and to be valued on those terms while rejecting and condemning beliefs and practices of paganism. Works like Snorra Edda and Heimskringla seem instead to suggest an environment where traditions linked specifically to vernacular non-Christian mythology were present and valued in society, leading them to be reframed as acceptable in a Christian context rather than rejected.
} 
varied considerably, but, if poems were documented through dictation, the transcriber was likely familiar with the tradition if not competent to perform in it, and had quite probably heard the particular poem before. ${ }^{20}$ Rather than today's ideals of transcription, the transcriber's knowledge of the tradition may have affected and even filtered what was written, so that writing the poem may have been a process of co-production (Ready 2015).

Documented eddic poems generally make the metrical form salient. They sometimes have prose insertions and there are scattered lines that are non-ideal, but they do not float in and out of poetic form. ${ }^{21}$ The consistent salience of the metrical form makes it possible that the documentation process often or usually resulted in texts closer to certain formal ideals than might be normal in other situations. If eddic poetry was documented through dictation, the situation can be assumed to have been staged - i.e. pre-organized - arranging for one person to present and another person with the materials, place, and perhaps light to transcribe. The situation would almost certainly be different from a customary performance context. If the person dictating was not the organizer of the situation, he may have felt self-conscious or awkward, particularly when the process itself was first being attempted. The shift in mode to dictation or performance of short series of verses in bursts, followed by pauses as they are written down, breaks up the flow of presentation and can cause difficulties for even the most skilled and confident performer. ${ }^{22}$ The setting may thus have resulted in less-than-ideal presentations, especially when first getting started, while the presenter's attention may have been more on the unusual situation than on the poetry (e.g. Lord 1960: 126). The different mode of presentation, or regular breaks after short sets of verses, could be particularly disruptive for a presenter who conceived of the text not as simply words and phrases but as performed speech. Comparative evidence suggests that the presenter would gradually become more accustomed to the process and situation, with the consequence that difficulties may be more concentrated at the beginning than at the end of a presentation.

Albert Lord's discussion and examples are widely known as a point of reference when considering dictation (e.g. 1960: 114-115 and ch. 6). He

\footnotetext{
${ }^{20}$ Medieval dictation of a poem for transcription is unlikely to be organized without it first having been heard.

${ }^{21}$ The poem Hárbarðsljóð might be considered an outlier here, which could reflect differences in its documentation context.

${ }^{22}$ See e.g. the survey of accounts from different traditions, concentrated on oral epic, in Ready 2015: 13-24.
} 
states that that "a dictated text, even when done under the best of circumstances and by the best of scribes, is never entirely, from the point of view of the line structure, the same as a sung text" (Lord 1960: 127). Although the claim is valid, some of the issues that Lord describes are linked to the type of tradition and are not so prominent in, for example, kalevalaic epic, which was documented extensively through dictation during the nineteenth and beginning of the twentieth century. The South Slavic singers described by Lord traditionally performed with musical accompaniment in a tradition of composition-in-performance, piecing together most passages formula by formula and line by line in a flow of continuous speech. For this type of tradition, removing the features that organize and facilitate that flow can be extremely disruptive (e.g. Lord 1960: 126-127). Eddic poetry diverged from other Germanic poetry not only in poetic form but also in performance practices. The poetry seems not to have been performed with musical accompaniment, nor is it described as 'sung' (Harris 1985: 116117). Eddic poems on mythological and heroic subjects also do not appear to have been composed in situ. Poems were not memorized in the modern sense of actively learning an absolute and invariable exemplar to be ideally reproduced without variation of a single morpheme. Nevertheless, they seem to have been internalized as regularly reproduced verbal texts. This makes for a very different situation for dictation, with the presenter trying to remember lines and passages, whether remembered as whole or as largely prefabricated but completed in situ.

The presentation of verses interacts with memory, whether or not with conscious, reflective self-assessment of the ongoing presentation. The role of memory is greater where poems are remembered as texts, rather than composed freely in situ, and less-than-ideal verses may be recognized and improved in repetitions. This type of process is reflected in Alvíssmál, where formulae only vary on their first use, and a more ideal form on their second use remains consistent thereafter. This does not mean that poems were invariable, but remembering formulae or whole lines and systems of lines plays a significant role in such poetry, and difficulty calling up the customary phrase for a particular passage can cause a presenter to stumble no less than any of us might when, mid-sentence, we find we cannot recall a key word or phrase. Composing is here considered an act of formulating potentially unique expressions, whether at the level of a single line or a whole poem, either in the course of presentation or in a situation allowing for deliberation. Remembering concerns both words and prefabricated units and frameworks and potentially whole stretches 
of text. Composing and remembering are here seen as complementary and interacting in an oral performance: even the most crystallized oral poetry may involve a degree of composition, while even the most variable oral poetry involves a degree of remembering prefabricated units and schemata of the idiom. The performance of oral poetry is commonly characterized by a continuous and regular flow of delivery that will normally prioritize ideal fluency, without pauses, false starts, etc. Not being able to remember a phrase or passage will thus normally lead to composition or simply moving forward, sometimes at the expense of semantic content (or even sense). The pressures of temporal delivery are removed in deliberative transcription from personal knowledge and also potentially from dictation, which might even open into discussion and corrections in the course of presentation. The transcriber might also edit the text in the process of transcription without consultation, or stop to question a verse, perhaps digressing into conversation. ${ }^{23}$ The possible factors in the situation are innumerable, but the perspectives outlined here offer a frame of reference for considering the cases below.

\subsection{Methodology}

An ideal of non-variation is taken as a dominant ideology in text reproduction, and formula usage that diverges from this ideal is assessed against that backdrop. All else being equal, variation in repeating formulae could reflect a performer's idiosyncratic handling of the poetic system (cf. Harvilahti 1992b: 95-96), impacts of a scribe on the transmission of a text (Frog forthcoming:§7), or problems of memory (as in Alvíssmál above) or other interference in the context of the initial transcription of a poem. Focus here is on repetitions within a single version of a text. Multiple uses of a formula or verse sequence within a poem create a context in which variation can be viewed, but a variation among only two or three uses remains ambiguous. The cases taken up below thus examine formulae in lists of a greater number of items in series, providing a larger number for comparison. The repeated use in relatively rapid and periodic succession is also assumed to make non-variation more salient in the documentation of the poem and its manuscript transmission.

\footnotetext{
${ }^{23} \mathrm{Cf}$. Gm 25.2, where it looks like Herjafǫrs 'of Óðinn' has been added to the end of a b-line as a clarification, and then the word order changes in the line's repetition in Gm 26.2 to syntactically integrate Herjafoðrs (cf. Bugge 1867: 80-81).
} 
Interpreting the background of individual variations uses so-called 'close reading', looking with great care and an analytical eye at a text and its features in context, down to minutia of detail. More pragmatically, the case studies below are each of a numbered inventory of knowledge or questions about mythic knowledge, so other examples of similar inventories are first reviewed to establish a frame of reference within the corpus. Variations in each case are correlated with potential relevant indicators of competence, confidence, and fluency in the passage of the text or poem, and also corresponding potential indicators of confusion, tension, or disruption, with the hope of identifying interpretable patterns.

\subsection{Sources}

The primary materials of this study are the texts of eddic poems as they appear in the Codex Regius (GKS 2365 4to) and AM 748 I a manuscripts, working centrally from the edition of Sophus Bugge (1867) alongside the diplomatic editions of Ludv. F. A. Wimmer and Finnur Jónsson (1891) and Vésteinn Ólason and Guðvarður Már Gunnlaugsson (2001) of the Codex Regius and of Finnur Jónsson (1896) of AM 748 I a; I have also made use of images of both manuscripts available at handrit.is as well as relevant later manuscripts of which digital images are available. Comparisons with Snorra Edda are made with reference to Anthony Faulkes' edition of Gylfaginning and the Prologue (Snorri Sturluson 2005), with consideration of Finnur Jónsson's edition (Snorri Sturluson 1931).

\section{Ordinal formulae}

I use the term ordinal formula to refer to a formula that has an open slot,$^{24}$ which is regularly completed by ordinal numbers to form a series. Ordinal formulae are used in several eddic poems, where the longer series are particularly linked to inventories of units of mythic knowledge. Such numbered lists are exclusively found in poems in the ljóðaháttr meter. Outside of Vafprúdnismál and Grímnismál, these are inventories of things

\footnotetext{
${ }^{24}$ The concept of formulae with slots and slot fillers was introduced into discussions of formulaic language in oral poetry by Paul Acker $(1983 ; 1998)$.
} 
that can be performed with supernatural effect, found in Hávamál, Sigrdrífumál and Grógaldr.

\subsection{Hávamál 146-163}

The ordinal formula in Hávamál is used in a list of eighteen items. The list opens with Ljód ek pau kann 'Songs I know those' (Háv 146.1) with hjálp heitir eitt 'help one is called' beginning the second half of the stanza; this is followed by the ordinal formula Pat kann ek $\{i t\}$ \# 'That I know \{the $\} / \mathrm{a}$ \#' (curly brackets indicate an element of a formula that can be omitted; '\#' indicates a slot in the formula completed by an ordinal number). This section of Hávamál is preceded by the advice to Lodd-Fáfnir, in which there are twenty-one repetitions of the opening verse sequence introducing units of advice; the latter repeating sequence is a long line followed by two Vollzeilen, reduced in abbreviation to the first two words by the fifth use (Háv 112-137; see also Frog forthcoming: $\$ 3$ ). In contrast, the ordinal formula in the following section is written out with no more than normal abbreviation (the abbreviation " $\tilde{\mathrm{k}}$." is here only left unexpanded to "kann" so that it is saliently distinguishable from "kan", expanded to "kann"; I indicate line breaks systematically through all examples):

(1) Liop ec pa kann / er kannat pioðans kóna

(Háv 146.1-2)

hialp heitir eit $\quad$ / enn pat per hialpa mvn

(Háv 146.4-5)

Pat kann ec ii. / er pvrfo yta synir

(Háv 147.1-2)

Pat $\tilde{\mathrm{k}}$. ec. iii. / ef mer verpr parf micil

(Háv 148.1-2)

$\mathrm{P} a t \tilde{\mathrm{k}}$. ec et iiii. / ef mer fyrðar bera

(Háv 149.1-2)

Pat $\tilde{k}$. ec it v. / ef ec se af fári scotinn

(Háv 150.1-2)

Pat $\tilde{\mathrm{k}}$. ec et vi. / ef mic serrir pegn

(Háv 151.1-2)

Pat $\tilde{\mathrm{k}}$. ec it .vii. / ef ec se havan loga

(Háv 152.1-2)

Pat $\tilde{\mathrm{k}}$ ec ip. viii. / er allom er

(Háv 153.1-2)

Pat $\tilde{\mathrm{k}}$. ec ip. ix. / ef mic napr $\mathrm{v} m$ stendr

(Háv 154.1-2)

Pat $\tilde{\mathrm{k}}$. ec ip. x. / ef ec se tvnripor

(Háv 155.1-2)

Pat $\tilde{\mathrm{k}}$. ec ip. xi. / ef ec scal til orrosto

(Háv 156.1-2)

Pat $\tilde{\mathrm{k}}$. ec ip xii. / ef ec se atre vppi

(Háv 157.1-2)

$\mathrm{P} a t \tilde{\mathrm{k}}$. ec ip xiii. / ef ec scal pelgn vngan

(Háv 158.1-2)

Pat $\tilde{\mathrm{k}}$. ec ip. xiiii. / ef ec scal fyrða lilpi

(Háv 159.1-2)

Pat $\tilde{\mathrm{k}}$. ec ip. xv. / er gól pioð reyrir

(Háv 160.1-2)

Pat $\tilde{\mathrm{k}}$. ec ip. xvi. / ef ec vil ins svinna mans

(Háv 161.1-2)

Pat kann ecip. xvii. / at mic mvn seint firraz

(Háv 162.1-2)

Pat $\tilde{\mathrm{k}} . \quad$ ec ip. xviii. / er ec æva kennig

(Háv 163.1-2)

The first unit or strophe is formally different from those that follow and does not use the ordinal formula. After this, the ordinal formula regularly 
completes an a-line followed each time by a different b-line that opens the specific unit of knowledge. The b-line either begins ef 'if' followed by a first-person singular pronoun or er 'which' in all but the seventeenth item. The number in the ordinal formula regularly carries alliteration (although undesirably in the seventh with the verb); alliteration can be assumed to drive the phraseology of the b-line. The line structure of each unit being introduced is not regular. Although it is most common for long lines and Vollzeilen to alternate, both are also found used in series; counting each a-line, b-line and Vollzeile separately, the number of verses in each unit varies from three to nine; counting each long line singly, the number of verses varies from two to seven.

The formula Pat kann ek $\{i t\}$ \# varies only in the absence of $i t$ from the second and third uses; it is never to be found in combination with annarr 'second', which seems to be a convention of language that drives at least a minimum variation in the formula's phraseology. ${ }^{25}$ Use of it beginning with the fourth rather than the third item could be an incidental variation but it is equally possible that the absence was a less-than-ideal realization or an accident of carrying non-variation from the second to the third use rather than shifting immediately to use with $i t$. An omission by the scribe is also possible, although the formula is not subject to extensive abbreviation, so it would have to be attributed to accident. As a variation, the omission of $i t$ is superficial. Alternation in the orthography of $i t$ between "et", "it", and "ip" is lexically incidental from the perspective of oral variation, but the inclination to non-variation may, in this case, also be reflected in the orthography: the form "ip" becomes regular beginning from the eighth use.

\subsection{Sigrdrífumál 22-37}

The ordinal formula Pat raeð ek pér \{it\} \# 'That I advise you \{the\}/a \#' is used in Sigrdrifumál eleven times, beginning from the first item. Although the regular alternation of long lines and Vollzeilen predominates, Vollzeilen are also used in series in $S d 25$ and $S d$ 35. Outside of these passages, editors treat the text as composed in regular stanzas, yet the number of verses between uses of the ordinal formula vary, with supplementary comments or elaborations given for the third ( $S d 25)$, fourth $(S d 27)$, sixth $(S d 30)$, ninth $(S d 34)$ and tenth $(S d 36)$ items in the inventory. Only the

\footnotetext{
${ }^{25}$ The variation in the abbreviation of kann, changing back from " $\tilde{k}$." to "kas" with the seventeenth item occurs with the first use after beginning to write on the verso of the leaf.
} 
first six uses are preserved in the Codex Regius, at which point is the lacuna of the missing quire:

(2) Codex Regius (GKS 2365)

$\begin{array}{llllll}\text { Pat ręp } & \text { ec } & \text { per } & \text { ip } & \text { fyrsta } & \text { / at pv vip frondr pina } \\ \text { Pat } \mathrm{r} . & \text { e. } & \text { per. } & & \text { a. } & \text { / at pv eip ne svęrir } \\ \text { Pat } \mathrm{r} . & \text { e. } & \text { p. } & & \text { iii } & \text { / at pv pingi a } \\ \text { Pat } \mathrm{r} . & \text { ec. } & \text { per } & \text { it. } & \text { iiii. } & \text { / ef byr forldǫpa } \\ \text { Pat } \mathrm{r} . & \text { ec. } & \text { per } & \text { it } & \text { v. } & \text { / pottv fagrar ser } \\ \text { Pat } \mathrm{r} . & \text { ec. } & \text { p. } & \text { it } & \text { vi. } & \text { / pot } t \text { mep } \text { seggiom fari }\end{array}$

(Sd 22.1-2)

(Sd 23.1-2)

(Sd 24.1-2)

(Sd 26.1-2)

(Sd 28.1-2)

(Sd 29.1-2)

The remainder of the stanzas are preserved only in later paper manuscripts, where they conclude the poem. ${ }^{26}$ The oldest manuscripts with the remaining stanzas are from the seventeenth century. Bugge identified the oldest as AM 738 4to, copied in 1680, and AM $166 \mathrm{~b} 8 \mathrm{vo}$, which he dated to the second half of the seventeenth century (1867: 234), although the relevant leaves were lost from the latter within a few decades of his edition (Ussing et al. 1894: 429). Pórdís Edda Jóhannesdóttir (2011a; 2011b) argues that the neglected manuscript Lbs 1199 4to, not used by Bugge or later editors of the poem, exhibits features that suggest it may be the closest to the Codex Regius text:

(3) Lbs 1199

$\begin{array}{lllllll}\text { Pad } & \text { ræd } & \text { eg } & \text { pier } & \text { hid } & \text { İ. } & \text { / ad. pu vid frændur pyna } \\ \text { Pad. } & \text { r. } & \text { e. } & \text { p. } & & \text { Iİ } & \text { / ad pu Eid nie Suorier } \\ \text { pad } & \text { r. } & \text { eg } & \text { p. } & & \text { III. } & \text { / ad pu pingi a } \\ \text { P. } & \text { r. } & \text { e. } & \text { p. } & \text { ip } & \text { IV. } & \text { / ef byr fordæd } \\ \text { p. } & \text { r } & \text { e. } & \text { p } & & \text { V. } & \text { / pottu fagrar sier } \\ \text { p. } & \text { r. } & \text { e. } & \text { p. } & & \text { Vİ. / pott med seggium far: } \\ \text { P. } & \text { R. } & \text { eg } & \text { p. } & & \text { VII. } & \text { / Eff pu sakar deiler } \\ \text { p. } & \text { r. } & & \text { p. } & & \text { VIIII. / ad pu skallt vid Illu sia } \\ \text { p. } & \text { r. } & & \text { p. } & & \text { IX. / ad pu Naam Biargel } \\ \text { P. } & \text { r. } & & \text { p. } & & \text { X } & \text { / ad pu truer alldre } \\ \text { P. } & \text { r. } & & \text { p. } & & \text { XI. / ad pu vid illu sęr }\end{array}$

(Sd 22.1-2)

(Sd 23.1-2)

(Sd 24.1-2)

(Sd 26.1-2)

(Sd 28.1-2)

(Sd 29.1-2)

(Sd 31.1-2)

(Sd 32.1-2)

(Sd 33.1-2)

(Sd 35.1-2)

(Sd 37.1-2)

As in Hávamál, alliteration is carried by the number in every use with a different $b$-line that opens the specific unit of information; b-lines never-

\footnotetext{
${ }^{26}$ In Volsunga saga, extended quotation of Sigrdrifumál stops with the preceding section of the poem (i.e. $S d 21$ ), although the stanzas of the rest of the poem appear to have been transformed into a series of prose statements of advice (Bugge 1867: 232-234; cf. Finch 1965: 39-40). Pórdís Edda Jóhannesdóttir (2011a: 121) finds that all but one manuscript of the poem datable to the seventeenth century concludes with the same text. In later manuscripts, text from Volsunga saga became linked to the poem by manuscript redactors. For example, ÍB 299 4to, rather than copying the opening verses of the incomplete stanza in the Codex Regius, picks up in the prose advice of Volsunga saga following $S d 28$; the same passage is included in Lbs 1689 4to, which contains Sigrdrifumál through Sd 37.
} 
theless predominantly begin the same (at pú 'that you', of which ef pú 'if you' may be a variation). Abbreviation generally matches the Codex Regius through the fourth use, including the absence of $i$ from the third, although Roman numerals are used already beginning from the first. After the fourth use, it is omitted without abbreviation, as is $e k$ ' $\mathrm{I}$ ' after the seventh; the reduction of the number of words reflected in an abbreviated text sequence was common (as was variation in which words were represented in abbreviation).

AM 7384 to expands the abbreviations - also adding it to the third use until the fourth item, which is the first on a new page (16r). The switch to Roman numerals seems to have caused some confusion, reflected in "i4" rather than "iv". The abbreviations generally remain uniform, although it disappears from the last three uses of the formula: ${ }^{27}$

(4) AM 738 4to

Pad ræd eg pier hÿd fyrsta / ad pü vid frændur pÿna

Pad ræd eg pier annad / ad pu eid ne sverier

(Sd 23.1-2)

pad ræd eg pier ed pridia / ad pu ey ä pingi

(Sd 24.1-2)

P $\quad \mathrm{R} \quad \mathrm{e} \quad \mathrm{p}$ ip i4 / ef byr fordæda

(Sd 26.1-2)

$\mathrm{p} \quad \mathrm{R}$ e $\mathrm{p}$ ip $\mathrm{v}$ : / pöttu fagrar siäer

(Sd 28.1-2)

$\mathrm{P} \quad \mathrm{R} \quad \mathrm{e} \quad \mathrm{p} \quad \mathrm{ip}$ vi / pött med seggium fare

(Sd 29.1-2)

p r i $\quad$ p ip vij / ef pu sakardeilir

(Sd 31.1-2)

$\mathrm{p} \quad \mathrm{r} \quad \mathrm{i} \quad \mathrm{p} \quad \mathrm{i}$ : viij / ad pu skallt vid illu sia

(Sd 32.1-2)

p: r: e p ix / ad pu Naaum $m$ biarlger

$\begin{array}{llllll}\mathrm{p} & \mathrm{r} & \mathrm{e} & \mathrm{p} & \mathrm{x} & \text { / ad pu truer alldzeij }\end{array}$

$\mathrm{p} \quad \mathrm{r} \quad \mathrm{e} \quad \mathrm{p} \quad \mathrm{xi} \quad / \mathrm{ad}$ pu vid illu siaer

In the eleventh use, the Roman numeral appears "xii", although the "ii" is probably a sloppy double stroke to mark a thick "i" as "ii" is written "ij" elsewhere in this text.

\subsection{Grógaldr 6-14}

The ordinal formula Pann gel ek pér \{it\} \# 'This incant I to you $\{$ the $\} / \mathrm{a}$ \#' is used for all nine items presented in Grógaldr's numbered list. Like the lists in Hávamál and Sigrdrífumál, the b-line formula is different with each use. Each unit in the list is uniformly structured as two pairs of

\footnotetext{
${ }^{27}$ In AM 738 4to, the seventh and eighth uses of the formula seem to abbreviate it carelessly, so that the "e" becomes hardly recognizable, as does the " $r$ " in the eighth. Something seems to have impacted the copying process on the ninth use: the abbreviations become clear, yet it disappears.
} 
alternating long lines and Vollzeilen with the exception of $G g$ 10, which has an additional Vollzeile. AM 738 4to's text is presented in (5):

(5) AM 738 4to

\begin{tabular}{|c|c|c|c|c|}
\hline Pan $n$ gel ek per & & fyrstan $n$ & / pan $n$ kuepa fiolnytan $n$ & $(G g 6.1-2)$ \\
\hline Pan $n$ gel ek per & & an $n$ an $n$ & / er pu arna skalt & $(G g 7.1-2)$ \\
\hline $\operatorname{Pan} n$ gel ek per & & pryðia & / ef per pióðir & $(G g 8.1-2)$ \\
\hline Pan $n$ gel ek per & $\operatorname{in} n$ & fiorpa & / ef pik filanpr stanpa & $(G g 9.1-2)$ \\
\hline $\operatorname{Pan} n$ gel ek per & & fimta & / ef per fiotur verpa & $(G g$ 10.1-2) \\
\hline $\operatorname{Pan} n$ gel ek per & $\operatorname{in} n$ & Sietta & / ef pu a sio kemur & $(G g 11.1-2)$ \\
\hline $\operatorname{Pan} n$ gel ek per & $\operatorname{in} n$ & siøunpa & / ef pik sekia kemur & (Gg 12.1-2) \\
\hline $\operatorname{Pan} n$ gel ek per & in $n$ & atta & / ef pik uti nemur & $(G g$ 13.1-2) \\
\hline $\operatorname{Pan} n$ gel ek per & & Nijunpa & / ef pu vyp pan $n$ naddgøfgna & $(G g$ 14.1-2) \\
\hline
\end{tabular}

Bugge's edition presents inn regularly for all uses of the formula except the second, and all b-lines after the first as beginning $e f$ 'if' followed by a secondperson singular pronoun. Jónas Kristjánsson and Vésteinn Ólason (2014: 189) identify the oldest manuscript as Stockh. papp. 8vo nr. 15 (not used by Bugge); their edition also presents inn with the third question (2014: 438).

\subsection{Overview of ordinal formulae in Hávamál, Sigrdrífumál, and Grógaldr}

Ordinal formulae reviewed in this section remain formally very uniform. Hávamál exhibits a different formula with the first item in the series whereas Sigrdrifumál and Grógaldr both use the ordinal formula also for the first item. The only formal variation is the presence or absence of the article ittinn, a variation that seems to be required for annarr 'second', which may impact its variability in repetition generally; absences of the article later in the series nevertheless appear likely attributable to manuscript abbreviation simply rendering it invisible. The formula is combined with a different $b$-line in each use and alliteration is consistently carried by the number. All three lists exhibit preferred ways of beginning the $b$-lines.

\section{Alternating b-lines in Vafprúðnismál}

In Vafprúðnismál, the ordinal formula Segðu pat \{it\}\# 'Say you this \{the\} \#' is used to open a series of twelve questions. Unlike ordinal formulae above, the b-line does not begin the unique unit of knowledge, nor is 
the b-line different for each use of the formula. Sets of questions in Vafprúðnismál are linked through the repetition of an opening long line and Vollzeile, producing what can be described as macro-parallelism (Urban 1986: 26-29) through which paired questions and answers become perceivable as parts of parallel groups.

\subsection{Indications of ideals of non-variation}

The repeating verse sequences opening questions are subject to extended abbreviation with suspension. The abbreviation strategy may conceal some variation, but it simultaneously indicates a perceived sameness of the verse sequence. In the first such sequence, Vafprúðnir's questions to Óðinn open with the common formula Segdu \{mér $\}\{$ pat $\} X$ 'Say you $\{$ to me $\}$ this $\}$ X', in which one or both optional words may appear. In the first use, the pronoun mér 'to me' is used, switching immediately to pat 'this' in repetitions ("?" represents a punctus elevatus, used to indicate omitted words):

(6) Segpv mer gagn rapr / allz pv agólfi I vill // pins vm freista frama Segdv pat gagnrapr?

(Vm 11.1-3)

$\mathrm{S}$ egðv p. g?

( $V m$ 13.1-3)

Segpv p. g.

/ a? |

(Vm $15.1-3)$

( $V m$ 17.1-3)

Say to me / this Gagnráðr / as you on the floor want // yours (um) to try your fame?

The number of repetitions is relatively few, but the regularity of the last three uses continues into the ordinal formula Segðu pat \{it\} \# in the following series of questions. The Segðu \{mér\} \{bat\} $X$ is a widely attested formula, used in the repeating series of questions in Alvíssmál and Fjölsvinnsmál and also more widely (see Kellogg 1988: s.v. 'segja'). Use with Segðu mér $X$ or Segðu mér pat $X$ are the most common forms whereas Segðu pat X seems rare outside of Vafbrúðnismál; examples of variation within a poem are normally expansions after the first use and never otherwise alternation between short forms with only mér or pat (Frog 2021:§5). Segðu mér pat X appears held as generally ideal in the corpus. Mér in the first use in (6) is most likely a less-ideal realization on the formula's first use, following which the presenter finds a preferred form on the first repetition and sticks with it.

Non-variation also characterizes the opening verse sequence of the questions following the numbered inventory: ${ }^{28}$

${ }^{28}$ Bugge (1867: 72) adds "vm" before "reynda regin" based on the expletive particle of 
(7) Fjolp ec for / fiolp ec freistapac //f. ec relynda regin ( Vm 44.1-3) Fiolp ec. f. /f. e. f?

Fiolp ec f. / f.

Much I travelled / much I tried // much I tested the gods

These examples suggest that the presenter of the poem subscribed to ideals of non-variation. The opening variation in the first series of questions suggests that he did not always come up with an ideal form of a verse on the first use of a formula.

\subsection{The ordinal formula within the recurrent verse sequence}

The sequence of questions forming a numbered inventory is separated from the preceding text, beginning on a new line with a large capital. The rubric "capitulum" 'chapter' has been added in red ink in a space at the end of the line. Within the poem, this division marks the transition from the first parts of the poem, including the giant's questions, to Óðinn's questions, which dominate the rest of the poem until its conclusion. ${ }^{29}$

For the first ten questions, the ordinal formula is integrated into an opening address of the giant that is a long line and Vollzeile in length, and the question is formulated in a following long line and Vollzeile. The answer then follows in two pairs of alternating long lines and Vollzeilen. The structure of both questions and answers is generally regular, although there are two answers that are only a single long line and Vollzeile $(\mathrm{Vm}$ $27,31)$ and one that includes an additional long line $(\mathrm{Vm} \mathrm{38}) .{ }^{30}$ With the eleventh and twelfth cycles of the inventory, variations appear in the macro-parallel structure. The eleventh question is formulated as a single

found in AM $748 \mathrm{I}$ a; it is possible that the same could be a variation concealed by abbreviation here.

${ }^{29}$ This rubric is also found following $R m 25$ and following the concuding verses of Guðrúnarkviða II (and cf. also Bugge 1867: ii-iii, 396), making it seem unlikely to antedate bringing together the mythological and heroic collections into a single manuscript.

${ }^{30}$ The additional long line stands out because it is an independent clause juxtaposed between a long line and Vollzeile that form a coherent clause, leading it to be interpreted as an interpolation (e.g. Gering 1927: 173). The line is also formally unusual. Its short lines are end-rhymed, which in ljóðaháttr (outside of lists of names) is otherwise only found in combination with parallelism (in short lines or Vollzeilen in Skm 28.3-4; in Vollzeilen in Háv 134.11-12), and the rhyme is on heavy disyllables, which is unusual for a b-line's cadence (found in Vafprúdnismál in Vm 2.5, 3.5 and 33.2). 
long line and Vollzeile ( $\mathrm{Vm} 40)$ as is the answer ( $\mathrm{Vm} 41)$ or these together form a question without an answer. The twelfth question is formed through variation of the repeating opening lines and the answer repeats the following long line while both have an extra Vollzeile or long line ( $\mathrm{Vm}$ 42, 43). The ordinal formula Segðu pat $\{$ it $\}$ \# is regular, with it appearing in all instances except with annarr, and all questions open with a variation of the long line and Vollzeile except for the eleventh: ${ }^{31}$

(8) S egðv pat ip eína / ef pit opi dvgir // oc pv vafprvðnir vitir. (Vm 20.1-3) Segðv pat. ii. /e.p. ę. d. //oc p. v? I Segðv pat. ip iii. / allz pic svinnan lqvepa // oc p. v. v. (Vm 24.1-3) Segðv pat. ip iiii.l/a. p. f? (Vm 26.1-3) S egðv pat. ip v. / a. p. f? $\quad(\operatorname{Vm} 28.1-3)$ Segðv pat. it. vi. / a. I p. s. q. (Vm 30.1-3) S egðv pat. ip vii. / a. p. s. $\quad$ q. $\quad(V m 32.1-3)$ Segðv pat. ip viii. / a. p. f? (Vm 34.1-3) Segðv pat. ip ix. / a / p. s. q. // e? (Vm 36.1-3) S egðv pat. ip. x. / a. pu tiva rác // all vafðrvðnir vitir (Vm 38.1-3) Segðv pat. et. xi. / hvar ytar tvnom i // haggvaz hverian dag. (Vm 40.1-3) Seglpv pat. ip xii. / hvi pu tiva rác //áll vafðrvðnir vitir (Vm 42.1-3)

\subsection{The b-line formula and lack of alliteration in the eighth question}

The ordinal formula's use in a repeating line sequence appears to be an outcome of adapting it to the question and answer dialogue. As in other ordinal lists, the b-line varies in relation to the number in the question, although the number does not always exhibit alliteration. Three formulae with variations are used in the b-line. These formulae, including variation in the formula allz pik svinnan/fróðan kveða 'as you are said to be clever/ wise', relate to alliteration with the numbers, as shown in Table 1.

Any two ordinal numbers that carry the same alliteration have a different b-line formula, one of which can also be used with the remaining two numbers by alliterating with the verb segja to produce a metrically well-formed line. The relationship of b-lines to alliteration suggests a system of alternatives driven by alliteration comparable to that found in

\footnotetext{
${ }^{31}$ This is matched in AM 748 I a, where the formula becomes abbreviated to the first letter of each word and Roman numerals are also used for the numbers, while pat rather than it disappears from the fifth and then the seventh through the last questions (or possibly $p u$; i.e. rather than "p. p." appears "p.", written "pv." in $V m$ 42).
} 
Tab. 1. B-line formulae and ordinal number alliteration (deviations from expectation underlined)

\begin{tabular}{llll}
\hline Alliteration & formula & $\begin{array}{l}\text { relevant for ordinal } \\
\text { numbers }\end{array}$ & used for \\
\hline vocalic alliteration & ef pitt œði dugir & annarr, átti, ellifti & $\underline{\text { einn, annarr }}$ \\
alliteration on /f/ & allzpikfróðan kveða & fyrstr,fjórði, fimti & fjórði, fimti, átti \\
alliteration on /s/ & allzpik svinnan kveða & sétti, sjaundi & sétti, sjaundi \\
alliteration on /t/ & allz/hvípú tíva rǫk & tíundi, tólfti & tíundi, tólfti \\
other alliteration & allzpik svinnan kveða & priði, níundi & priði, níundi \\
verse series unused & - & - & $\underline{\text { ellifti }}$ \\
\hline
\end{tabular}

Alvíssmál. When the system is recognized, non-ideal variations come into sharper focus. First:

a. The b-line of the eighth question does not produce metrical alliteration

The system anticipates use of the b-line for vocalic alliteration, while the formula allz pik svinnan/fróðan kveða 'as you are said to be clever/ wise' would produce a metrical alliteration if used with svinnr rather than fróðr. The variation is unlikely to be the result of scribal error since it is in a series of the formula's svinnr variations. A copyist's skip of the eye would require jumping across about eight lines of text (based on the Codex Regius). A misreading of a long $s(f)$ as a Carolingian miniscule $f$ is unlikely when the manuscript seems only to have used Insular $f(f) ; 2$ moreover, variations of the formula are abbreviated in different ways in the Codex Regius as "f?" and "s. q.", pointing to a salient distinction between the formula variations in the exemplar. ${ }^{33}$ The variation in the eighth question also points away from deliberative transcription from personal knowledge, which would allow the presenter (i.e. writer) to look back at earlier choices, noting that either of the other b-line formulae used up to that point would produce a metrical alliteration. The b-line of the eighth question therefore appears likely to reflect an oral formulation that was transcribed by a second individual. The variation might be accidentally introduced if the a-line and b-line were dictated separately, but dictation

\footnotetext{
${ }^{32}$ Carolingian minuscule $\mathrm{f}$ is used in only three instances in the Codex Regius, all in corrections (Guðvarður Már Gunnlaugsson 2019: 365).

${ }^{33}$ AM 748 I a transcribes the first use with the abbreviation "f.", which would match the Codex Regius, followed by regularized abbreviations of "f. k." alongside "s. k." for the following uses (see also Frog forthcoming).
} 
in such short units could easily lead into confusion by interrupting syntax and rhythm, which would likely leave additional traces through the poem. Intuitively, it seems far more likely that dictation would have proceed by utterances that were syntactically or metrically complete.

\subsection{The lack of the introductory sequence in the eleventh question}

Predictable phraseology is disrupted a second time when vocalic alliteration comes around again:

b. The eleventh question does not continue with a b-line in Table 1

c. It is the only of the poem's 22 questions that does not open with a repeating verse series

d. It is either half the length of the poem's 21 other questions or has no answer

e. If the second long line and Vollzeile is an answer, this is half the length of 19 of the poem's 21 other answers (i.e. all except $V m 27$ and 31)

$\mathrm{f}$. The second long line and Vollzeile is an answer, the answer does not clearly identify the location 'where' of the question

Transition immediately to the question in the b-line breaks the macroparallelism that is otherwise regular through the dialogue and thus appears non-ideal.

Questions in the poem regularly begin with an a-line while the postpositional use of $l$ in the final position indicates that $V m 40.2$ is a b-line, so the phrasing would not result from a copyist accidentally skipping a stretch of text. Moreover, the suspension of abbreviations would lead even the ordinal formula alone to be read as representing the full opening series of verses, as seen in (6) and (7) above. Seventeenth- and eighteenthcentury copyists interpreted the a-line this way, expanding the verse group, leaving the following b-line and Vollzeile without an a-line. ${ }^{34}$ Beginning the question in the b-line requires some degree of conscious composition that diverges from all patterns in the poem. The variation cannot be reasonably attributed to a copyist and can with confidence be identified

\footnotetext{
${ }^{34}$ For example, reproducing the b-line from the eighth question in AM 738 4to, 55v, ÍB 68 4to, 61r, reproducing the b-line from the tenth question in Lbs 1689 4to, 20r-20v, or following the a-line with "etc" in ÍB 299 4to, 14v. For additional discussion of variations, see Bugge 1867: 71.
} 
with the poem's initial documentation. The variation is extremely unlikely for a deliberative process of writing. Other ordinal inventories present the main unit of information immediately in the b-line with alliteration on the number. Although the variation diverges from other questions in Vafprúðnismál, it follows broader conventions of ordinal formula use. It can be understood as a non-ideal expression that was an organic outcome in oral delivery, which would point to a dictation situation. In this case, the variation likely followed an interruption while the preceding verses were transcribed (during which there may also have been distractions).

Either the answer is omitted entirely or the question is unusual in its short duration. Units of mythic knowledge in eddic ordinal inventories may be longer than a pair of alternating long lines and Vollzeilen or be elaborated by an additional verse group but they are almost never shorter. ${ }^{35}$ Dialogic poetry in ljóðaháttr in particular is generally characterized by giving a turn of speech not less than a pair of alternating long lines and Vollzeilen, so $V m$ 27, 31 and 41 look short on the backdrop of the corpus as well as of the poem. ${ }^{36}$ Snorra Edda reproduces the question and a full-length answer for Vm 31 (Snorri Sturluson 2005: 10). Although reconstructing verses through Snorra Edda's prose is highly problematic, Gylfaginning 19 is devoted to presenting the names and information contained in the lines of $V m 27$ followed only by a second, commensurate set of names and information (Snorri Sturluson 2005: 21), long suspected to reflect knowledge of additional verses from this passage. ${ }^{37}$ As an answer to the eleventh question, a single long line and Vollzeile looks non-ideal, particularly when it follows on an anomalously-phrased question.

Together, the question and answer correspond to a passage in Snorra $E d d a$ commonly considered as the answer to the eleventh question:

(9) Segðu pat it ellipta / hvar ýtar túnum í // hǫggvast hverjan dag allir einherjar / Óđins túnum í // họggvast hverjan dag

( $\operatorname{Vm} 40.1-3)$

val peir kjósa / ok ríða vígi frá // sitja meirr um sáttir saman val peir kjósa / ok ríða vígi frá // sitja meirr um sáttir saman

(Snorri Sturluson 2005: 34)

( $V m$ 41.4-6)

(Snorri Sturluson 2005: 34)

\footnotetext{
${ }^{35}$ Only in Háv 147 and $V m 27$ and 31, and possibly in $\mathrm{Gm}$ 5, if counted as two units.

${ }^{36}$ Vafbrúdnismál's passages are quite regular, otherwise only having an extra line in $\mathrm{Vm} 38$, 42 and 43 , and in the giant's statement that closes the poem, where it appears to be intended for rhetorical effect ( $V m$ 55.7-9).

${ }^{37}$ Bugge (1867: 69) even proposed a reconstruction of the lines; cf. Wimmer 1896: 110, also reproduced in Neckel \& Kuhn 1963: 49.
} 
'Say you that the eleventh / where men in the courts // fight every day' 'all the einherjar / of Óđinn in the courts // fight every day'

'the slain they choose / and ride from battle // sit then (um) reconciled together' 'the slain they choose / and ride from battle // sit then (um) reconciled together'

The exemplar of AM 748 I a followed the a-line Segðu pat it ellipta immediately with the lines as found in Snorra Edda, apparently treating the a-line as a suspension for the whole question. Accepting that beginning the question in the b-line is an oral-derived variation leads the AM 748 I a variant to be seen as a copyist's revision (the reverse being improbable, since the question would otherwise begin in the a-line). Whereas modern editions present the Codex Regius' question with AM 748 I a's answer, not reproducing the question is an indicator that a copyist saw the question hvar ýtar túnum $i$ as an adaptation of Óðins túnum $i$. This would suggest that the variation in the Codex Regius had exchanged the name Óðinn, which specifies a location, with a question word along with a poetic word for 'men' that can carry vocalic alliteration for the nominal subject of the a-line. With Segðu pat it ellipta, this most likely situation-specific adaptation seems to have made the opening long line and Vollzeile a question. Initially, I viewed Vm 40.1-3 and 41.4-6 as question and answer. Rethinking it from the perspective of oral poetry, if AM 748 I a accurately reflects that $V m$ 40.2-4 are an adaptation of $V m$ 41.1-3, then I consider it more likely that the presenter elided the conventional beginning of the question with the conventional answer and simply pushed through. I suspect that the elision was simply considered a non-ideal realization - a type of variation - and that the presenter's main concern was that his verses were well-formed and well-ordered, not who spoke which line. Presumably, anyone who knew the poem would recognize what had happened, and recognize both question and answer that were fused together; in that circumstance, asking which lines were spoken by which speaker is not interesting if it is not enacted as a dialogue..$^{38}$

Something has clearly gone awry at the eleventh question, most likely occurring in oral delivery. If this is more or less correct, viewing the eleventh question as simply elided to the answer and the presenter then just pushing onward might seem to suggest dictation in the whole unit

\footnotetext{
${ }^{38}$ Marginal speaker notations and manuscript punctuation of this passage will not be discussed here.
} 
of alternating long lines and Vollzeilen. However, it could equally be suggested that a short burst of a single long line and Vollzeile would make it easier to accidentally elide the ordinal formula directly into the question. This would mean oral delivery in syntactic units, which is also how the Codex Regius but not AM 748 I a is punctuated. The presenter's main concern could still have been to keep the lines well-formed and wellordered, but, as two utterances separated by perhaps a minute, the transcriber or anyone listening may have interpreted the two parts as question and answer.

The rhythm of dictation has implications for the shortness of $V m 27$ and 31 (i.e. answers to the fourth and sixth questions). If the units of dictation were a single long line and Vollzeile each, these answers would be potential sites where the presenter may have accidentally jumped ahead to the next question. Alternately, if dictation was by the whole turn of each speaker of the poem, then the shortness of $V m 27$ and 31 would be salient in dictation, making it more likely that these were originally transcribed as complete answers, in which case it seems more probable a copyist accidentally skipped the second half of both in a common exemplar of both the Codex Regius and AM 748 I a. Assessing whether Vafprúdnismál was more likely dictated in syntactic units or turns of dialogue depends on $(a)$ whether it is considered more probable that the second half of two answers (not questions) was skipped in oral delivery or accidentally elided by a copyist, and also on $(b)$ which seems more probable for the elision of the eleventh question. In either case, the eleventh question, with or without an answer, points to a situation in which even a passage that was clearly non-ideal was written down, presumably more or less as presented.

\subsection{Variation in the twelfth question and answer}

In this context, the final exchange of the ordinal inventory exhibits variations that require comment:

$\mathrm{g}$. The b-line of the twelfth item varies that of the tenth by changing it into a question

h. The answer in $V m$ 43.1-2 repeats $V m$ 42.4-5 in the question, both followed by a varying Vollzeile and an additional line

The variation between the b-lines of the tenth and twelfth questions is of only one word: allz 'as' is exchanged for the interrogative hvi 'how, why'. The twelfth question differs from those preceding it by turning 
the repeated statement of Vafprúðnir's great knowledge into a question about how he knows it rather than as introducing an inquiry about some piece of that knowledge; the second part of the question then repeats the general demand. Vafprúðnir's reply then differs from answers to previous questions by repeating the second long line of the question, varying the following Vollzeile, and, as in the question, following this with an additional line,$^{39}$ before proceeding to the answer proper. ${ }^{40}$ Although the variations in the twelfth question and answer set these apart from those that preceded them, they appear linked to the change in emphasis of the question and the conclusion of the section of the dialogue. Rather than non-ideal, they seem more likely to be rhetorical and, on the backdrop of conventions of non-variation, exchanging allz for $h v i$ was probably quite marked. Introducing an interrogative at the beginning of the b-line in the twelfth question seems likely to have been part of the tradition or at the very least an established strategy of the particular presenter of the poem, creating the possibility that anticipating this may also have been a factor influencing the eleventh question's jump to an interrogative in the b-line.

\subsection{A cardinal number in the ordinal formula and vocalic alliteration}

The eighth and eleventh questions both appear as non-ideal formulations that seem to have been produced in situ. Both anticipate use of the b-line suited for vocalic alliteration. Use of such a b-line in the first two questions and then 'forgetting' it in the course of performance seems unlikely and contravenes the more general pattern. It thus raises the question of whether the formula ef pitt œði dugir 'if your knowledge suffices' was considered non-ideal by the presenter so that it was not used again.

The first use of this b-line may be linked to a non-ideal variation:

i. The ordinal formula's first use has the cardinal einn rather than the ordinal fyrstr ${ }^{41}$

\footnotetext{
${ }^{39}$ The additional line in the question is a Vollzeile; that in the answer may be a long line or Vollzeile depending on how one scans it (scanned as a long line until Neckel).

${ }^{40} \mathrm{~A}$ similar type of repetition between question and answer systematically structures the first group of four questions, with variations especially in a-lines while the Vollzeilen are regular $(\mathrm{Vm} 11-18)$. In the final series of six questions, the complete Vollzeile is once repeated between question and answer $(\mathrm{Vm} 50-51)$ and the concluding phrase twice $(\mathrm{Vm}$ $46-47,54-55)$. Repetition of the long line is specific to $V m 42-43$.

${ }^{41}$ The leaf preserved with Vafprúðnismál in AM 748 I a begins with the b-line formula ef
} 
Ordinal formulae are not otherwise used with cardinal numbers, although only Sigrdrifumál and Grógaldr use such formulae with the first item in a series ( $S d$ 22.1, Gg 6.1). If fyrstr had been used in Vafprúðnismál, the b-line allz pik fróðan kveða would presumably have accompanied it for alliteration. The data is too thin to determine whether fyrstr or einn was established in the presenter's dialect of the tradition, though it is possible that einn was non-ideal.

Use of einn drives vocalic alliteration for use of ef pitt œði dugir, which is metrically well-formed, and this is repeated, predictably, with annarr. Thereafter follow five uses of the allz pik svinnan/fróðan kveða formula before requiring vocalic alliteration for átti. Following two uses of allz pik svinnan kveða carrying alliteration with sétti and sjaundi, the b-line formula is varied for átti to allz pik fróðan kveða. A third use of the preceding b-line would have achieved metrical alliteration, but this option may have been less noticeable if alliteration with the number was in focus. This otherwise peculiar choice points to an attempt to find a different b-line formula. The b-line formula shifts to allz pú tíva rqqk with the tenth question, and the eleventh diverges completely from the a repeating verse sequence when vocalic alliteration is needed again. Rather than these non-ideal solutions being accidental moments of confusion (which can, of course, occur), they seem more likely to reflect the same problem of difficulty coming up with the appropriate b-line for vocalic alliteration. The ef pitt œði dugir deviates from all subsequent b-line formulae, which begin allz pú/bik, and preferred openings of the b-line seem characteristic of other ordinal formulae above. In the eighth question, insofar as 'forgetting' the b-line ef pitt œði dugir, already used twice, is unlikely, varying the formula from the preceding question probably reflects a preference for another line beginning allz pú/pik.

The repeated b-line opening allz pú/pik builds up to the variation of alls for $h v i$ in the last question. After five repetitions of allz pik, the divergence of ef pitt œði dugir from the pattern would be salient, as it would not have been in the first questions. This hypothesis remains conjectural, but clear difficulties later in the inventory correlate with vocalic alliteration, with the implication that ef pitt œð dugir was not, at that point, considered suitable. If this is correct, it looks like the presenter did not recall the conventional formula and formulated a solution for vocalic alliteration in situ already with einn. CEði pér dugi 'may your knowledge suffice for you' is used

pitt œði dugir, from which use of einn can be assumed. 
early in the poem ( $V m$ 4.4) and may have been adapted here to generate the b-line. Such an adaptation would point to competence and flexibility in the presenter's handling of the poetic idiom, although the solution was abandoned after the repeating b-line opening alls pú/pik was initiated.

\subsection{A perspective on variation in Vafprúðnismál}

Variation is an organic part of all oral poetry. In that respect, the variations considered here can be considered normal. The interest in these non-ideal solutions are as indications of problems that in turn may offer insights into the initial documentation of the poem. For whatever reason, the presenter seems to have had difficulty where a b-line for vocalic alliteration is predicted. Other features of the poem suggest the presenter's competence in the poetic idiom. We might interpret what happened in the eleventh question as a mistake, yet the elision of the ordinal formula with the b-line to form a question both indicates the ability to find a solution and seems connected with internalized knowledge of the poetry. Vm 5 may also be mentioned here as "the only purely narrative ljóðaháttr strophe in existence" (Gunnell 1995: 277), presenting third person narration in verse where all other ljóðaháttr poems would have prose (see also Gunnell 1995: 185-203). Ljóðaháttr is characteristically used for direct speech (Quinn 1992) and Terry Gunnell (1995: ch.3) has argued convincingly that poems in ljóðaháttr appear to have been used in a monologic and dialogic performance genre. The written text of Vafprúðnismál is neither accompanied by nor includes any prose. If Gunnell is correct, the anomaly of $V m 5$ could be explained as the presenter of the poem remaining in the poetic idiom for the third person exposition where presenters of other ljóðaháttr poems would shift into prose. Rather than belonging to the oral tradition of Vafbrúðnismál, Vm 5 would then be a by-product of the documentation process that would reflect the individual's fluency in the idiom.

'What happened' in the background of documenting the text is unclear, but the variations appear to derive from oral delivery, documented by a second person. What is most striking about the presenter's difficulties with b-lines for vocalic alliteration is that the solutions seem to decline rather than improve. They start off with a metrically well-formed b-line in the first two questions, followed rather surprisingly by varying a second formula so that it does not alliterate in the eighth question, and then the repeating opening verse sequence collapses entirely in the eleventh. Rather than deeply meditated solutions, the non-ideal verses and passages look 
like spontaneous choices in the flow of ongoing performance. Estimating that the pause might be something like a minute for transcribing a half strophe or two minutes for a full strophe, it looks like this presenter, at least, may not have been deeply concerned about 'what comes next' during the interims of presentation as the transcriber was catching up. $\mathrm{He}$ may simply have been sitting there, waiting, perhaps attentive, watching his counterpart work, perhaps others present, observing, offered scattered moments of distraction, or perhaps he was simply... bored.

The progression of $b$-lines solutions for vocalic alliteration does not reflect especial concern. Instead, it could be symptomatic of growing disinterest or even annoyance with the documentation process itself. Such a possibility might seem novel and moderately amusing yet incidental, but it warrants consideration because it could also impact on the presentation of the poem. Scholarship tends to take the eddic poems for granted; textual issues come into focus where these are somehow disruptive or seem anomalous, but the impacts of the performance situation may also be at other levels. For example, the exchange of the twelfth question and answer points to a rhetorical climax, following which some sort of change is expected, such as Vafprúðnir asking another series of questions. Instead, Óðinn simply continues his interrogation. If the presenter was growing impatient, annoyed or had simply lost interest, he may also have hastened the presentation to its conclusion. Such a possibility is impossible to determine with only one preserved variant of the poem, but it is important to consider that a performance might also be non-ideal at other levels than only lines or question and answer, and that the presenter of a poem might enthusiastically try to find ways to elaborate a poem and display his ability, or equally decide to keep it short or wrap up abruptly.

\section{Difficulties starting and alternative ordinal formulae in Grímnismál}

The numbered list of otherworld locations in Grímnismál presents a complex case. The ordinal inventory exhibits a formal regularity in which each unit is composed in a pair of alternating long lines and Vollzeilen, although the structure of passages is not uniform throughout the poem. The internal organization of the first three passages varies from those that follow. Like the ordinal inventory in Hávamál above (1), the opening 
long line and Vollzeile present a general introduction to the list followed by the first item in the second long line. The second passage then presents a different location in each half. All other ordinal inventories begin numbering from the first item, although Hávamál and Vafprúdnismál use a cardinal number, without and with the ordinal formula, respectively. None of the first three locations in Grímnismál are numbered. An ordinal formula first appears at the beginning of the third passage, where the fourth location is numbered the 'third' $(\mathrm{Gm} 6){ }^{42}$ The numbering of locations proceeds regularly thereafter, yet the formula changes for the next three locations and then changes again for the following four. Units in the inventory become formally regular from the fifth/'fourth' location $(\mathrm{Gm}$ 7), but, following the sixth/'fifth' ( $G m$ 8), the list contains two additional stanza-like units ( $G m 9-10)$. The structure of all the ordinal formulae is the same, with two open slots: the second receives the ordinal number while the first is filled by the common noun bor 'settlement' and by a place name in all uses thereafter. The name or noun in the first slot always carries alliteration rather than the number. Items are here presented in four groups by their ordinal formulae or lack thereof:

\begin{tabular}{|c|c|c|c|c|c|c|}
\hline i. & $\begin{array}{l}\text { Land er heilact } \\
\text { enn iprvðheimi } \\
\text { Ýdalir } \\
\text { alfheim I freýr }\end{array}$ & heita & & & $\begin{array}{l}\text { / er ec liggia se } \\
\text { / scal pórr vera } \\
\text { / par er vllr hefir } \\
\text { / gáfo i arðaga }\end{array}$ & $\begin{array}{l}(G m 4.1-2) \\
(G m 4.4-5) \\
(G m 5.1-2) \\
(G m 5.4-5)\end{array}$ \\
\hline ii. & $\begin{array}{l}\text { Bor } \\
\text { valascialf }\end{array}$ & $\begin{array}{l}\text { er sa } \\
\text { heitir }\end{array}$ & inn & priði I & $\begin{array}{l}\text { / er blið regin } \\
\text { / er vęlti sér }\end{array}$ & $\begin{array}{l}(G m 6.1-2) \\
(G m 6.4-5)\end{array}$ \\
\hline iii. & $\begin{array}{l}\text { Sacqva beccr } \\
\text { Glaðs heimr } \\
\text { Prym heimr }\end{array}$ & $\begin{array}{l}\text { heitir } \\
\text { heitir } \\
\text { heitir }\end{array}$ & $\begin{array}{l}\mathrm{e} n n \\
\mathrm{e} n n \\
\mathrm{e} n n\end{array}$ & $\begin{array}{l}\text { iiii. } \\
\text { v. } \\
\text { vi. }\end{array}$ & $\begin{array}{l}\text { / enn par svalar knego } \\
\text { / pars en gvll biarta } \\
\text { / er piazi I bío }\end{array}$ & $\begin{array}{r}(G m 7.1-2) \\
(G m 8.1-2) \\
(G m 11.1-2)\end{array}$ \\
\hline iv. & $\begin{array}{l}\text { Breiða [blik] } \\
\text { H iminbiorg } \\
\text { Folcvangr } \\
\text { Glitnir } \\
\text { Nóa tvn }\end{array}$ & $\begin{array}{l}\text { ero } \\
\text { ero } \\
\text { er } \\
\text { er } \\
\text { ero }\end{array}$ & $\begin{array}{l}\text { ín } \\
\text { en } \\
\text { inn I } \\
\text { inn } \\
\text { en }\end{array}$ & $\begin{array}{l}\text { sivndo } \\
\text { atto } \\
\text { nivndi } \\
\text { x. } \\
\text { xi. }\end{array}$ & $\begin{array}{l}\text { / enn par baldr hefir } \\
\text { / enn par heimdall } \\
\text { / enn par freyia rępr } \\
\text { / hann er gv lli I stvddr } \\
\text { / en } n \text { par niorp } r \text { I hefir }\end{array}$ & $\begin{array}{l}(G m 12.1-2) \\
(G m 13.1-2) \\
(G m 14.1-2) \\
(G m 15.1-2) \\
(G m 16.1-2)\end{array}$ \\
\hline
\end{tabular}

In Gm 5.1 and Gm 6.4-5, Ýdalir heita and Válaskjálf heitir exhibit an X heit-ir/-a formula, a formula type of which a multitude of examples is found in the corpus (see Kellogg 1988: s.v. 'heita'), including in (1) above

\footnotetext{
${ }^{42}$ The incongruity between the number of locations and the numbering in the list is found in both manuscripts of the poem and has long been recognized. See e.g. Gering 1927: 189.
} 
and elsewhere in Grimnismál..$^{43}$ The X heit-ir/-a inn \# formula is related to this but considered as a distinct type.

The examples of ordinal formulae in Grímnismál are:

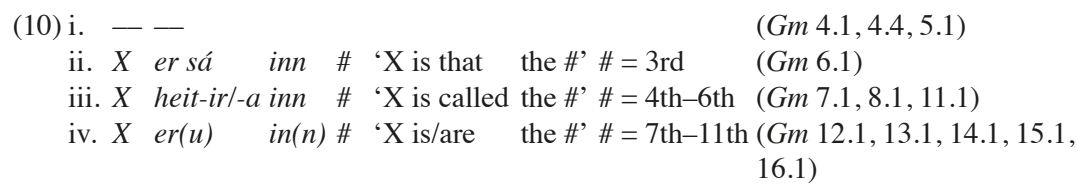

In contrast to $X$ heit-ir/- $a$ formulae, $X \operatorname{er}(u) Y$, where $\mathrm{X}$ is a noun in the nominative case, underlying ordinal formulae ii and iv, is only found in Grímnismál once outside of the ordinal inventory (Gm 33.1: Hirtir ero oc fiórir 'Harts there are also four'). ${ }^{44}$ When the construction is not common, formula ii looks like a variation of formula iv on its first use or both as variations of a $X e r /-u\{$ sá\} inn \# formula.

Even before considering the text in any detail, a number of features stand out as potentially irregular:

a. Three locations are named in the inventory before numbering begins (Gm 4-5)

b. The second and third locations are each presented in half the verses of other units, apparently forming a single unit together $(\mathrm{Gm} \mathrm{5)}$

c. Numbering begins by labelling the fourth location as the 'third' ( $\mathrm{Gm}$ 6)

d. The first ordinal formula is not completed with a place name ( $\mathrm{Gm} 6)$

e. The structure of units only becomes regular from the fifth/'fourth' item (before $\mathrm{Gm}$ 7)

f. The first ordinal formula varies lexically from its subsequent uses ( $G m$ 6)

g. A second, equivalent ordinal formula is then used for a series of three items $(G m$ 7-11)

h. The first ordinal formula is resumed for the last five items ( $\mathrm{Gm} 12-16)$

The presenter could of course handle the poetic system more freely than most performers (cf. Harvilahti 1992: 95-96), but then the irregularities would be expected to occur more or less uniformly through the inventory.

${ }^{43} X$ heit-ir/- $a$ in $G m$ 22.1, 38.1; X heitir enn in an unnumbered inventory in $G m$ 28.1; X heitir ANIMAL in Gm 25.1, 26.1,32.1,39.1.

${ }^{44}$ A similar construction is found with the noun in a dative ( $\left.G m 9.4\right)$, others are found with an adjective in the first position and also pá er $X$. 
Irregularities a-f are concentrated in $G m$ 4-6 and labelling the fourth location as the 'third' looks fairly clearly non-ideal, while the only irregularities in Gm 7-16 are, oddly enough, $\mathrm{g}-\mathrm{h}$ - the alternation of the ordinal formula - and the insertion of Gm 9-10, which appears irregular under scrutiny. Put simply, it looks like the presenter got off to a rough start but generally aimed at non-variation.

\subsection{Fourth = 'third'?}

Within Grímnismál's ordinal inventory, each unit appears to be conventionally presented through a pair of alternating long lines and Vollzeilen. This view is supported by comparison with other ordinal inventories, predicted by macro-parallelism as structuring the inventory, and consistent with evidence that non-ideal irregularities are concentrated in Gm 4-6, after which items in the inventory are formally regular. The presentation of two locations in $\mathrm{Gm} 5$ points to a difficulty that resulted in one formal unit of conventional length. The mix-matching in the numbering of the fourth location as the 'third' in $G m 6$ can be directly connected with this, as counting by formal units rather than named locations, then also pointing to $G m 5$ as non-ideal. In Grimnismál's ordinal formula, the place name systematically carries alliteration with the b-line. In principle, the long line for any location could be used with any numeral. Thus, Álfheimr could have been the third conventional place in the inventory and the collapse of two locations into Gm 5 resulted in numbering being off by one for the remainder of the list. Alternately, the numbering may have held priority, in which case the mnemonic significance of the numbering may have been to include all of the items in the list (i.e. counting up to eleven; cf. Sigrdrifumál) while their order could have varied considerably in the oral tradition. ${ }^{45}$ In either case, if two locations that would customarily be

\footnotetext{
${ }^{45}$ Gísli Sigurðsson (e.g. 2014) has revealed likely connections of some Old Norse mythology to observable phenomena visible in the sky. Snorra Edda identifies locations mentioned in Grímnismál as in the sky (Snorri Sturluson 2005: 23-24), creating the possibility that the ordinal inventory was linked to visible phenomena like constellations. Even then, there is nothing to suggest that the numerical order of the locations is linked, for instance, to an Old Norse zodiac. The locations are not presented as having spatial relations to one another in any source, although Prymheimr is identified with Jotunheimar (Snorri Sturluson 1998: 2; and not in the sky in Snorri Sturluson 2005: 23-24), making a position between the dwellings of Óðinn and Baldr seem doubtful. When other ordinal inventories seem simply to organize mythic knowledge numerically, Grímnismál may do the same.
} 
presented separately have been collapsed into a single passage, this has implications for the documentation context.

Like the difficulties with the eleventh question in Vafprúdnismál above, collapsing two formal units into one makes a background in oral delivery probable. Accepting that each location would be presented in a commensurate formal unit, the truncated presentation of Ýdalir points to difficulty in remembering the remainder of the passage, leading the presenter to push forward and complete it with a second location in situ. The priority of $G m 5$ as a formal unit then seems to have limited Álfheimr's presentation to a single long line and Vollzeile. Deliberative writing would have allowed an ordinal number to be added to the $X$ heit-ir/-a formula used with $Y$ dalir, for instance above the line, and seems generally less probable for the mixed numbering; it also would have allowed time to formulate complete units. Either deliberative writing or oral delivery in bursts of a single long line and Vollzeile would presumably allow the passage on Ýdalir to remain half its conventional length without also limiting the passage on Álfheimr. The formal structure of units as constituted of an alternating pair of long lines and Vollzeilen is regular for the entire passage and apparently conforms the presentation of two locations to this structure, suggesting that it was salient for the presenter. The most probable scenario is that the passage results from dictation in bursts of formal units, and the presentation of formal units was given priority over both interruption and, it is implied, the presentation of a full passage on Álfheimr.

At a glance, the long line with Álfheimr does not appear compatible for use with an ordinal formula because of Freyr's name in the a-line. In the inventory, gods' names otherwise only appear in the same long line with the place name when these alliterate, so Freyr's name would presumably not appear with Álfheimr and an ordinal formula. Gods' names otherwise appear in the second a-line in four out of the eleven other passages, always in the nominative case (Óðinn ok Saga in Gm 7.4, Hroptr in Gm 8.4, Skaði in Gm 11.4, Forseti in Gm 15.4). Freyr's name fills the place in the a-line where an ordinal formula could otherwise appear. Without his name, the lines would not specify to whom Álfheimr was given by the gods, which, if the lines are otherwise conventional, would presumably become clear in the second half of the passage. Completing the a-line with Freyr's name rather than an $X$ heit-ir/- $a$ or $X$ er/-u $Y$ formula may be semantically driven so that 'to whom' is specified. The possibility that Freyr was customarily named in the following a-line might then be related 
to the Codex Regius' scribe writing "freýr" in the nominative case and then adding a dot under the " $r$ " as a correction mark that the letter should be ignored. If it is correct that the long line would customarily be used with an ordinal formula, the variation with Freyr's name would be an in situ solution for conforming information in a full group of verses to the formal unit of $\mathrm{Gm} 5$ - a solution that points to the presenter's competence in collapsing information from a longer passage into a single long line and Vollzeile.

\subsection{Elaboration between $G m 8$ and $G m 11$ ?}

Following the sixth/'fifth' location, Glaðsheimr, where Valholl is said to be ( $G m$ 8), two passages present supplementary information about Valholl ( $G m$ 9-10). Elaboration of items in an ordinal inventory through extension was observed in Hávamál and by following a unit with one additional stanzalike unit in Sigrdrifumál. Gm 9-10 forms a longer elaboration, which may be incidental, yet each passage begins with the same long line and Vollzeile, so the number of lines adding information corresponds to what would be one unit in Sigrdrífumál. The initial repetition creates macro-parallelism that links $G m 9$ and 10 to one another while setting them apart from what precedes and follows them. The macro-parallelism gives the impression that they belong to a different list or poetic passage. An elaboration of an ordinal inventory would seem more likely to present the lines of information together as a single unit without a repeated introduction that does not add information and interrupts the macro-parallelism of the list.

In a tradition of poetry relying heavily on remembering passages, a performer may follow the tradition's networks of associations and jump from reciting one poem to what is customarily another. A similar case is found in the pair of questions and answers in Fáfnismál 12-15, where the questions are set apart from the rest of the dialogue by a repeating opening that looks like a variation of that in Vafprúðnismál (Segðu mér \{pat\} Fáfnir / allz pik fróðan kveða // ok vel mart vita 'Say to me \{that\} Fáfnir / as you are said to be wise // and indeed much know'). The questions are also distinguished by asking for general information about nornir and then about a location of ragna rok, which is characteristic of questions in Vafprúðnismál but beyond the scope of the rest of Fáfnismál's dialogue. ${ }^{46} \mathrm{Gm}$ 9-10 elaborate about Valhǫll, mentioned in $\mathrm{Gm}$ 8, whereas

\footnotetext{
${ }^{46}$ Earlier scholars interpreted these questions as an interpolation while more recent scholars
} 
Fáfnismál's question about nornir follows a mention of nornir in Fm 11. Whether accidental, intentional or socially established, these look like transpositions of passages customary for one type of use into another.

If Grímnismál's documentation is considered to result from dictation, the concentration of non-ideal features at the beginning of the text tip the probability toward Gm 9-10 not being a conventional part of the ordinal inventory. The digression might be linked to anticipating later descriptions in the poem and it is unclear whether the passages were conventional to Grímnismál or a different poem, but their appearance between Gm 8 and 11 , interrupting one sequence of macro-parallelism with another, seems more likely than not to have been non-ideal.

\subsection{Comparison with quotations in Snorra Edda}

Turning to the use of ordinal formulae, five of the items in Grimnismál's inventory are quoted in Snorra Edda (Snorri Sturluson 2005: 23-24, 26):

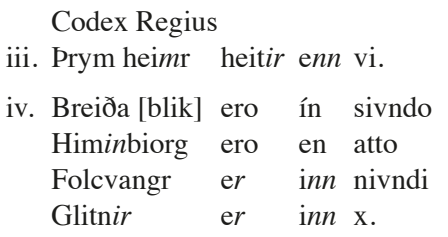

$\begin{array}{ll}\text { Snorra Edda } & \\ \text { Prymheimr } & \text { heitir } \\ \text { Breiðablik } & \text { heita } \\ \text { Himinbjorg } & \text { heita } \\ \text { Fólkvangr } & \text { heitir } \\ \text { Glitnir } & \text { heitir salr }\end{array}$

(Gm 11.1-2)

(Gm 12.1-2)

(Gm 13.1-2)

(Gm 14.1-2)

(Gm 15.1-2)

The items in Grímnismál use both formula types iii and iv whereas the quotations in Snorra Edda appear to conform to a principle of non-variation, exclusively using the $X$ heit-ir/-a formula, with a variation $X$ heitir salr with Glitnir. Snorra Edda's quotations may be conscious variations of an $X$ heit-ir/-a \{inn \#\} ordinal formula, since the ordinal number would be out of context when the passages are quoted individually. The possibility that the inventory may have been known without ordinal numbering cannot be excluded. Nevertheless, non-variation of the formula in Snorra $E d d a$ is more noteworthy because the quotations are presented with a variety of information between them, including passages from another poem (see Snorri Sturluson 2005: 23-26). The quotations highlight that the variation in the preserved poem Grimnismál is probably exceptional.

interpret them as sensical and meaningful in the poem ( $K L E \mathrm{~V}: 429)$, whereas I would say the two views are focusing on different concerns. 
Tab. 2. Possible alliterations between ordinal numbers and place names in the inventory

\begin{tabular}{lll}
\hline Alliteration & ordinal number & used for \\
\hline vocalic alliteration & (einn), annarr, átti, ellifti & Álfheimr, Ýdalir \\
alliteration on /f/ & fyrstr, fjórði, fimti & Folkvangr \\
alliteration on /n/ & níundi & Nóatún \\
alliteration on /s/ & sétti, sjaundi & Søkkvabekkr \\
alliteration on /t/ & tíundi, [tólfti] & - \\
alliteration on /p/ & priði & Prúðheimr, Prymheimr \\
\hline no alliteration possible & - & Breiðablik, Glaðsheimr, Glitnir, \\
& & Himinbjǫrg, Válaskjálf \\
\hline
\end{tabular}

\subsection{An avoidance of alliteration?}

When alliteration with the ordinal number shapes or determines the b-line in all other ordinal inventories, it becomes noticeable that the number never alliterates with a place name in Grímnismál. As seen in Table 2, the list could have been organized with alliteration also carried by the number in six of twelve potential uses of the formula.

If an ordinal formula were used in $G m 5$, either Ýdalir or Álfheimr would alliterate with annarr and be the only instance of alliteration with a number in the sequence. If the presenter felt that, ideally, alliteration with the number should be systematically avoided and had named the wrong location, this might have led him to consciously omit annarr from an $X$ heit-ir/-a inn \# formula or to exchange an X er/-u inn \# formula for a simple $X$ heit-ir/- $a$ formula. It is also possible that annarr was unintentionally omitted, in which case it is also accidental that other numbers in the list do not carry alliteration. However, when alliteration seems to drive choices between formulae and phrases elsewhere, potentially even affecting which cardinal direction is named in some lines (Lönnroth 2002: 17), it seems improbable that the first use of the ordinal formula would be with alliteration without doing so again thereafter.

The lack of numbering for the first three locations presents a third possibility that the presenter was having difficulty and only realized that the locations should be counted at some point between naming Ýdalir and the beginning of $G m$ 6, thus using a simple $X$ heit-ir/-a in Gm 5. Forgetting to number the first locations seems the most likely explanation when $G m$ 6 appears both to misnumber the location and also to deviate in structure 
by naming the location in the second rather than the first long line. If it is not accidental that numbers never carry alliteration in this ordinal inventory, it would suggest that alliteration would also be avoided with annarr, making Ýdalir non-ideal as the second location. In this case, the order of locations in the inventory would deviate from how the presenter would customarily organize them in a performance.

\subsection{Alternating ordinal formulae}

Particularly exceptional in the passage is that the ordinal formula used in $G m 6$ is exchanged for an alternative that is used without variation for the following three locations and then a form of the initial formula is resumed without variation for the rest of the list. Changing from a less ideal to a more ideal phrase is found in examples through the corpus, but this variation appears anomalous because it alternates between formulae rather than simply varying phraseology and because it is not completely random but rather appears regular for stretches of text. The initial switch from X er/-u \{sá\} inn \# in Gm 6.1 to X heit-ir/-a inn \# in Gm 7.1 might be considered linked to the use of a simple $X$ heit-ir/- $a$ in Gm 6.4. However, the initial use of $X$ er/- $u$ \{sá\} inn \# is between two simple $X$ heit-ir/-a formulae in $\mathrm{Gm} 5.1$ and 6.4. This makes it much less likely that the formula in $\mathrm{Gm} 6.4$ affected the choice of formula in $\mathrm{Gm} 7.1$ and does not account for the change back only in $G m$ 12.1, 16 lines later (counting by long lines). If the change back had coincided with the end of the digression in $G m$ 9-10, it might look like the presenter corrected himself to a more ideal formula following a disruption. The peculiarity is greater when the first alternation coincides with units attaining a more ideal structure that is maintained through the rest of the section, and then changing again in the stretch of passages that otherwise does not exhibit non-ideal features.

A feature of orthography could perhaps present a clue to something happening in the background of documenting the text. The $X$ er/-u\{sá\} inn \# formula appears with the ordinal number being written out $(\mathrm{Gm}$ 6), switches to Roman numerals with the change to the $X$ heit-ir/-a inn \# formula $(\mathrm{Gm} 7,8,11)$, and then resumes writing out numerals when changing back to the $X$ er/-u $\{$ sá\} inn \# $(G m 12,13,14)$, until using Roman numerals for the last two items in the list $(G m 15,16)$. Writing out ordinal numbers in a series, especially the first and second, and then switching to Roman numerals is common and the Codex Regius generally makes this switch near the beginning of an ordinal inventory; if there were only one 
change at the end of the list, it would not be surprising. Changing from Roman numerals to writing out numbers is exceptional, and doubly so when they seem to alternate here. Co-variation between how numbers are written and alternative ordinal formulae makes this still more striking. The copy of Grímnismál in AM 748 I a exhibits some slight differences in the transcription and text, but these appear most likely to have been introduced by a copyist. ${ }^{47}$ The Codex Regius is unambiguously the more reliable manuscript and remained close enough to its exemplars for the writing habits in earlier texts to be distinguishable (see also Vésteinn Ólason 2019: 235-242 and works there cited). If co-variation between use of Roman numerals and the ordinal formula is not accidental, then it points to some sort of a change between $G m 6$ and $G m 7$ and then a second change between $G m 11$ and $G m 12$. Insofar as it seems unlikely for a copyist to exchange one ordinal formula for another across only a short section of text, this variation in orthography would be rooted in the original documentation of the poem.

This is a big 'if' that is conditional on both the co-variation being nonrandom, and continuity in the different ways of writing out the numbers through earlier copying of the poem. That such continuity in copying is possible finds some support in Alvíssmál, in the writing of the dwarf's thirteen answers, each naming six ways something is called by different types of being. In the course of the dialogue, abbreviations develop for formulaic use of jotnar and álfar. Alv 24 shifts from these abbreviations to writing out the words in full, an indicator that 'something changed' in a process of writing or copying the poem. The 13 answers contain 78 terms or expressions for calling different things. Only two of these are found in multiple answers, both in repetitions of a line, and one repetition of each is in $A l v 24(A l v 24.3=26.3, A l v 24.5=32.5)$. Since non-repetition is otherwise the norm, repetition appears non-ideal, and the co-occurrence of both repetitions in connection with one passage makes it more likely that the problem was concentrated there rather than occurring independently in Alv 26 and 32. This view is supported by co-occurrence in Alv 24 of

\footnotetext{
${ }^{47} \mathrm{AM} 748 \mathrm{I}$ a is filled with regularizing spellings, minor variations and transparent copying errors (Finnur Jónsson 1896: iii-vii) whereas the Codex Regius seems generally to follow its exemplar more closely. In AM 748 I a, the numbers are all written out until the last three formulae (rather than only the last two), and, in the second use of the X heit-ir/-a inn \# formula, er 'is' is written in the place of heitir so that it looks like a type iv ordinal formula. The shift to Roman numerals late in the sequence in both manuscripts hints at a late shift also in a common exemplar.
} 
abbreviations being reset, pointing to an interruption or disruption at that point in the poem. The wording in Alv 24 is most likely attributable to the initial documentation of the poem, so whatever happened affected the person writing out the poem or both the oral presenter and transcriber (Frog 2011: 53). Observing this correlation between non-ideal lines and changes in abbreviation is dependent on accurately copying abbreviation or its lack from the exemplar. The case of Alvíssmál makes this possible for Grimnismál as well. That the scribe of the Codex Regius reproduced the numbers as found in the exemplar is increased by the contrast with other ordinal inventories where Roman numerals dominate.

Variation in orthography can only be attributed to a person writing out or copying the text, not to an oral presenter. Change in how numbers are written looks like a change in writing habits or practice followed by a change back. A single transcriber might transition from writing out numbers to use of Roman numerals, but switching back and forth is unlikely, and still less likely to co-vary with the change in formula. It is possible that a shorthand strategy might be reset following a break or interruption, as in Alvíssmál, but then the switch back to Roman numerals would likely occur at least as rapidly as earlier in transcription. Instead, it initially occurs immediately following the first number and later only after writing out three numbers (i.e. Gm 12-14). Alternately, the change to and from shorthand could reflect a change in the person writing out the poem. That a medieval text may be copied by multiple hands is a commonplace, although it would not be expected for such a short stretch of text. However, if Grimnismál was written down from dictation, the situation would be different from working with a written text, because stopping by either the presenter or transcriber would interrupt the other. If the person presenting the poem was an authority or should otherwise not be interrupted any more than necessary for the transcription, a change in the transcriber for a shorter period is possible. In sagas in Hauksbók (Jansson 1944) and in the Codex Upsaliensis' Snorra Edda (Sävborg 2012), different copyists have been shown to take considerably different attitudes to the exactitude with which they reproduce or rephrase and manipulate their exemplar. If the changes between writing numbers reflect different transcribers, the alternation in the ordinal formula from $G m 6.1$ to $G m$ 7.1, and back again from Gm 11.1 to $G m 12.1$ would correlate with a change between two people transcribing the poem, the second of whom wrote out the ordinal formula differently. In this case, one of the transcribers either consciously edited the ordinal formula to that of a preferred dialect, wrote it out as seemed 
natural without considering it to be 'different', or, if the dictation was in bursts of short passages, was more concerned with remembering and transcribing semantically-significant phrases and recalled the opening phrase of the passage through his own dialect. If the co-variation between writing numbers and the ordinal formula is not accidental - a big 'if' - it points to a relationship between the transcription and the alternation between ordinal formulae. This relationship seems most easily explained by a change between two people transcribing the text, in which case the alternation between formulae would point to an aspect of co-production in the written text (e.g. Ready 2015: 27) that would probably otherwise remain invisible.

If there was a second transcriber, the regularity of structural units makes it look like these were the units of dictation, in which case any such transition is most likely between those units. The second writer would then have been responsible for only $G m 7-11$, which is just twenty long lines and Vollzeilen, thirty short lines and Vollzeilen, or 107 words in Bugge's edition. Basically, it looks like someone stepped in and took over the work of the first scribe for maybe ten minutes, or a bit longer, although the amount of time depends on the copying process. Odd as this might at first seem, it looks like the second transcriber stepped in while the first ran off to take a pee. The passage is embedded not just within the poem but linked to only a few strophes within the ordinal inventory. If it does indeed reflect a change in the transcriber, it suggests a situation in which it was undesirable to interrupt the process of writing, even if only for a relatively short break. The shift in orthography would thus imply a situation where one person dictated and another transcribed while others were present and able to trade roles with the transcriber - and the person dictating should not be interrupted. This interpretation remains an extremely conjectural possibility (how could it not?), but it accounts for the exceptional alternation between ordinal formulae in the Codex Regius' text.

\subsection{A perspective on variation in Grímnismál}

A concentration of features at the beginning of Grimnismál's numbered inventory point to the performer having difficulty at the beginning of the list so that it was not realized in an ideal way. Some scholars may be sceptical that naming two locations in Gm 5 is non-ideal, but there is a concentration of features in this part of the text that stand out against other ordinal inventories and against the corpus more broadly, and these features have cumulative implications. The regular structure of items after Gm 6 
suggests that the concentration of such features at the beginning was nonideal, since they would otherwise be more evenly distributed through the inventory (cf. Gripisspá). I began this investigation with the expectation that the obvious irregularities like mis-numbering at the beginning of the inventory were directly related to the exceptional alternation between ordinal formulae. The lack of numbering at the beginning of the list does indeed appear connected with the presenter, but the alternation between formulae begins as the units of the inventory become regular, and they instead seem to correlate with a corresponding variation in how numbers are written. The features of the text suggest a process of dictation, with the presenter probably reciting by formal units of a pair of alternating long lines and Vollzeilen. The alternation between ordinal formulae is very exceptional and difficult to account for, leading to the hypothesis that there was a change in the person transcribing dictation from $\mathrm{Gm} 7$ to 11 , after which the first transcriber resumed. It remains possible that the alternation of formulae reflects an aberrant type of variation on the part of the performer. The two-scribe hypothesis is only preferable on the condition that co-variation of the writing of numbers and alternation of ordinal formulae is not random.

\section{Implications for the documentation of eddic poems}

The eddic corpus is so firmly established as a frame of reference in the scholarship that the poems in their preserved forms get taken for granted. The discussions of the numbered inventories in both Grimnismál and Vafprúdnismál point to documentation situations in which the poems were presented orally by one person while another wrote them down. In both inventories, potential indicators point to presentation in short bursts of lines. In Grímnismál, Gm 5 suggests presentation in regular pairs of alternating long lines and Vollzeile. It is more difficult to assess Vafprúðnismál. Indicators that the Codex Regius' exemplar was extremely close to the first transcription of at least Alvíssmál and Grimnismál, even in details of abbreviation, may increase the probability that the omission of the second half of $V m 27$ and 31 have occurred in dictation. The omission only of the second half of more than one answer in short succession within the ordinal inventory might also tip the scales in that direction, although these are answers to the fourth and sixth questions, before problems begin with numbers that would carry alliteration. Whatever the case, if the dictation of ljóðaháttr poetry was commonly in regular formal units, it might make 
the verse groups in the written poems look more regular than they might have been in other contexts. The irregularities in both examples further suggest that, when the presenter had difficulty remembering something or mixed something up, he simply pushed through the passage, producing solutions in situ, as would be likely for a customary oral performance. The irregularities in these examples suggest that the presenters did not pause to deliberate between lines or correct what was said. The curious case of alternating formulae in Grimnismál presents the possibility that a transcriber might write down equivalents of what was said, perhaps like writing out what someone says in their dialect in one's own. The coproduction entailed in transcription from dictation nevertheless allowed non-ideal verses and passages to enter into writing, which is itself interesting.

With all of these examples, and also with the numerous instances of minor variations on a formula's first use elsewhere, the key question that easily goes unasked is: Why are they there for us to see them? In other words: Why were non-ideal dictated lines and passages not revised? The text resulting from dictation seems to have gone unedited: no one seems to have gone through it and adjusted details where these might be amiss. The texts do not give the impression of having first been written out on a wax tablet to then be read by, or read out to, the presenter and 'corrected'. Both the two-scribe hypothesis for formula alternation in Grimnismál and the associated example from Alvíssmál would point to transcription directly onto vellum. There are clear cases of so-called scribal performance, in which a copyist uses knowledge of the poetry and poetic system in order to revise an oral-derived poetic text, as in the case of the Helgi poems discussed by Joseph Harris (1983 [2008]: 191-202) or the revision of the eleventh question in AM 748 I a's Vafprúdnismál. Nevertheless, the ordinal inventories reviewed above seem to suggest that the norm was simply to write out the poems more or less as they were spoken - blunders, unique solutions and all - and then subsequent copyists reproduced them that way. Focus here has been on sites in the texts where non-ideal variations are apparent owing to the number of examples in a repeating series with which they can be compared. When the lines and whole passages are for the most part technically well formed, it raises a question of how many other sites there may be in the corpus where passages are non-ideal, but there is no frame of comparison to identify it. This raises methodological issues for text analysis of poems, if the verses, phraseology or even organization of a poem may be non-ideal. However, 
just because poetry is oral does not make every variation equally good, and it is reasonable to infer that at least some of the variations discussed above were transparently considered as 'not how it should be' if not simply 'wrong' or 'bad' even by the presenter. Scholarship today tends to view a written text as 'the' poem, and yet, if Vafprúðnismál's elision of question and answer or Grimnismál's elision of two locations into a single passage was 'not how it should be', it raises the question of what people imagined the thing being written down to be.

Transcribing a dictated text as the poem without indication of an interest or need to edit or revise even passages where something has obviously gone wrong suggests an understanding of what the eddic poems are as things made of language. Although the articulation of a line or passage might be better or worse, whatever was dictated appears to have been conceived as capturing 'the poem' in writing. This might be compared to early nineteenth-century collectors of oral kalevalaic poetry, who simply wrote down whatever was dictated or sung in one go and were satisfied that they had gotten that person's variant. They sought to collect as many variants from different people as they could manage, because they tended to imagine individuals' variants as imperfect while enabling reconstruction of an ideal text through comparison. ${ }^{48}$ The writing of at least these eddic poems seems to reflect a similar idea of the poem being captured in one go, but without the corresponding way of looking at variations as things to be polished out and corrected in order to present a poem in its most ideal form. The lack of any editing or correction suggests an idea of 'the poem' as whatever is orally presented from beginning to end. The performance principle of simply pushing through, formulating solutions in situ rather than stopping to find a more ideal solution, seems to have extended to the written text. The result is 'Grímnismál', or 'Vafbrúdnismál', or whatever else has been performed - i.e. the variant is 'the poem' (cf. Lord 1960: 21, 28; see also Foley 2002: 11-21). An oral performance is commonly assessed and discussed by those who hear it, and is also connected to the authority and skill of the performer. The lack of editing and revision even of problematic lines and passages suggests that there was not, at least when these poems were written, an idea that the delivered text should or even could be improved.

\footnotetext{
${ }^{48}$ Only toward the end of the nineteenth century is a collection technique developed of getting performers to both sing and dictate the same poem, leading to a composite that is more complete and ideal (Saarinen 1994: 180).
} 
This leads to the question of how the manuscript text itself was understood, materially objectified and separated from the person. Where oral and written traditions are interwoven, performance will often be in focus as an activity, without concern for whether it is based on personal knowledge and competence or recited from a script. In his work with Rotenese ritual poets (who were also mostly literate), James J. Fox (p.c.) found it common that the poets, listening to recordings made of their performances, would refer to and discuss these as though it were a third person. Rather than the ideal or even necessarily particularly good representations of particular oral poems, several if not many of the texts in the eddic corpus may be quite close to whatever was produced in a single, clumsy dictation situation. Instead of being polished, it is necessary to consider that these text scripts may, at least initially, have each been seen as 'a' performance of the particular poem - not 'my', 'your', 'his' or 'her' performance, but as 'a' performance, which might equally be discussed and criticized. Returning to the production and copying of the poems in order to be used, if the written texts were 'performances' with lines and passages that are less than ideal, it raises the question of whether the written poem was imagined as something that people should recite verbatim, or if it was more of a guide.

\section{Bibliography}

Acker, Paul, 1983: Levels of Formulaic Composition in Old English and Old Icelandic Verse. Unpublished PhD dissertation, Brown University, Providence, RI. Acker, Paul, 1998: Revising Oral Theory: Formulaic Composition in Old English and Old Icelandic Verse. New York.

Acker, Paul, 2019: A History of Oral Formulas and Eddic Poetry, unpublished paper presented at the conference The Formula in Oral Poetry and Prose: New Approaches, Models and Interpretations, $5^{\text {th }}-7^{\text {th }}$ December 2019, Tartu, Estonia.

Amodio, Mark, 2004: Writing the Oral Tradition: Oral Poetics and Literate Culture in Medieval England. South Bend, IN.

Arant, Patricia, 1990: Compositional Techniques of the Russian Oral Epic, the Bylina. New York.

Bugge, Sophus, ed., 1867: Samundar Edda: Hins Froða. Christiania.

Coleman, Joyce, 1996: Public Reading and the Reading Public in Late Medieval England and France. Cambridge.

Doane, A. N., 1994: The Ethnography of Scribal Writing and Anglo-Saxon Poetry: Scribe as Performer. Oral Tradition 9(2): 420-439. 
Dronke, Ursula, ed. \& trans., 1997: The Poetic Edda II: Mythological Poems. Oxford.

Finch, R. G., ed. \& trans., 1965: Volsunga saga - The Saga of the Volsungs. London.

Finnur Jónsson, 1896: Håndskriftet nr. 748, 4 to, bl. 1-6, i den Arna-Magnceanske samling (brudstykke af den aeldre Edda) i fototypisk og diplomatisk gengivelse. København.

Foley, John Miles, 1990: Traditional Oral Epic: The Odyssey, Beowulf, and the Serbo-Croation Return Song. Los Angeles.

Foley, John Miles, 2002: How to Read an Oral Poem. Urbana.

Foley, John Miles, 2010: Verbal Marketplaces and the Oral-Literate Continuum. In: Along the Oral-Written Continuum: Types of Texts, Relations, and their Implications. Ed. S. Ranković, with L. Melve \& E. Mundal. Turnhout. Pp. 17-37.

Foley, John Miles, \& Peter Ramey, 2012: Oral Theory and Medieval Studies. In: Medieval Oral Literature. Ed. K. Reichl. Berlin. Pp. 71-102.

Frog, 2011: Alvíssmál and Orality: Formula, Alliteration and Categories of Mythic Being. Arkiv för Nordisk Filologi 126: 17-71.

Frog, 2016: Linguistic Multiforms in Kalevalaic Epic: Toward a Typology. RMN Newsletter 11: 61-98.

Frog, 2019: Approaching Ideologies of Things Made of Language: A Case Study of a Finno-Karelian Incantation Technology. Folkloristika: Journal of the Serbian Folklore Society 4(1): 211-257.

Frog, 2021 (forthcoming): Text Ideology and Formulaic Language in Eddic Mythological Poems. Saga-Book.

Frog, forthcoming (under review): How the Hell Do You Read This? - The Evolution of Eddic Orality through Manuscript Performance. In: Old Norse Poetry in Performance. Ed. A. Ferreira \& B. McMahon. London.

Frog \& William Lamb, 2021 (in press): A Picasso of Perspectives on Formulaic Language. In: Weathered Words: Formulaic Language and Verbal Art. Ed. Frog $\&$ W. Lamb. Cambridge, MA. (Milman Parry Collection of Oral Literature.)

Gil'ferding, A. F., 1894: Онежския былины, записанныя Александром Федоровичем Гильфердингом летом 1871 года.1. Санкт-Петербург.

Gísli Sigurðsson, 1990: On the Classification of Eddic Heroic Poetry in View of the Oral Theory. In: Poetry in the Scandinavian Middle Ages: Atti del $12^{\circ}$ Congresso Internazionale di Studi Sull'Alto Medioevo Spoleto 4-10 Septembre 1988. Spoleto. Pp. 245-255.

Gísli Sigurðsson, 1998: Ingangur. In: Eddukvaæði. Ed. Gísli Sigurðsson. Reykjavík. Pp. ix-li.

Gísli Sigurðsson, 2014: Snorri’s Edda: The Sky Described in Mythological Terms. In: Nordic Mythologies: Interpretations, Intersections, Institutions. Ed. T. R. Tangherlini. Berkeley. Pp. 184-260.

Guðvarður Már Gunnlaugsson, 2019: Palaeography. In: The Codex Regius of the Poetic Edda: Konungsbók Eddkvœðða GKS 2365 4to. Reykjavík. Pp. 345-451. 
Gunnell, Terry, 1995: The Origins of Scandinavian Drama. Woodbridge.

Harris, Joseph, 1983 [2008]: Eddic Poetry as Oral Poetry: The Evidence of Parallel Passages in the Helgi Poems for Questions of Composition and Performance. In: Joseph Harris, 'Speak Useful Words or Say Nothing': Old Norse Studies. Ed. S. E. Descis \& T. D. Hill. Ithaca. (Islandica 53.) Pp. 189-225.

Harris, Joseph, 1985: Eddic Poetry. In: Old Norse-Icelandic Literature: A Critical Guide. Ed. C. J. Clover \& J. Lindow. London. (Islandica 45.) Pp. 68-156.

Harvilahti, Lauri, 1992a: Kertovan runon keinot: Inkeriläisen runoepiikan tuottamisesta. Helsinki.

Harvilahti, Lauri, 1992b: The Production of Finnish Epic Poetry - Fixed Wholes or Creative Compositions? Oral Tradition 7: 87-101.

Haymes, Edward R., 2004: The Germanic Heldenlied and the Poetic Edda: Speculations on Preliterary History. Oral Tradition 19: 43-62.

Jansson, Sven B. F., 1944: Sagorna om Vinland I: Handskrifterna till Erik den rödes saga. Lund.

KLE: von See, Klaus, et al., 1997-2019: Kommentar zu den Liedern der Edda I-VII. Heidelberg: Universitätsverlag C. Winter.

Lord, Albert B., 1960: The Singer of Tales. Cambridge. (Harvard Studies in Comparative Literature 24.)

Lord, Albert Bates, 1995: The Singer Resumes the Tale. Ithaca.

Lönnroth, Lars, 1971: Hjalmar's Death-Song and the Delivery of Eddic Poetry. Speculum 46: 1-20.

Lönnroth, Lars, 2002: The Founding of Miðgarðr (Voluspá 1-8). In: The Poetic Edda: Essays on Norse Mythology. Ed. P. Acker \& C. Larrington. New York. Pp. 1-25.

Mellor, Scott, 1999 [2008]: Analyzing Ten Poems from The Poetic Edda: Oral Formula and Mythic Patterns. Lewiston. [PhD dissertation, University of Wisconsin, Madison, originally titled: 'Function and Formula: An Analysis of Ten Poems from the Codex Regius'.]

Mundal, Else, 2010: How Did the Arrival of Writing Influence Old Norse Oral Culture? In: Along the Oral-Written Continuum: Types of Texts, Relations, and their Implications. Ed. S. Ranković, with L. Melve \& E. Mundal. Turnhout. Pp. 163-181.

Neckel, Gustav, \& Hans Kuhn, eds., 1963: Edda: Die Lieder des Codex Regius nebst vewandten Denkmälern I: Text. 4. umgearbeitete Aufl. Heidelberg.

O'Keeffe, Katherine O'Brien, 1990: Visible Song: Transitional Literacy in Old English Verse. Cambridge.

Quinn, Judy, 1990: Voluspá and the Composition of Eddic Verse. In: Poetry in the Scandinavian Middle Ages: Atti del $12^{\circ}$ Congresso Internazionale di Studi Sull'Alto Medioevo Spoleto 4-10 Septembre 1988. Spoleto. Pp. 303-320.

Quinn, Judy, 1992: Verseform and Voice in Eddic Poems: The Discourses of Fáfnismál. Arkiv för Nordisk Filologi 107: 100-130.

Quinn, Judy, 2016: The Editing of Eddic Poetry. In: A Handbook to Eddic Poetry. Ed. C. Larrington, J. Quinn \& B. Schorn. Cambridge. Pp. 58-71. 
Ready, Jonathan L., 2015: The Textualization of Homeric Epic by Means of Dictation. TAPA 145: 1-75.

Ready, Jonathan L., 2019: Orality, Textuality, and the Homeric Epics: An Interdisciplinary Study of Oral Texts, Dictated Texts, and Wild Texts. Oxford.

Reichl, Karl, 1985: Oral Tradition and Performance of the Uzbek and Karakalpak Epic Singers. In: Fragen der mongolischen Heldendichtung, III. Ed. W. Heissig. Wiesbaden. Pp. 613-643.

Saarinen, Jukka, 2013: Behind the Text: Reconstructing the Voice of a Singer. RMN Newsletter 7: 34-43.

Siikala, Anna-Leena, 1990: Interpreting Oral Narrative. Helsinki.

Snorri Sturluson, 1931: Edda Snorra Sturlusonar udgivet efter håndskrifterne. Ed. Finnur Jónsson. København.

Snorri Sturluson, 2005: Edda: Prologue and Gylfaginning. Ed. A. Faulkes. $2^{\text {nd }}$ edn. London.

Sävborg, Daniel, 2012: Blockbildningen i Codex Upsaliensis: En ny metod att lösa frågan om Snorra eddas ursprungsversion. Maal og Minne 2012(1): 12-53.

Thorvaldsen,Bernt Øyvind,2006: Sváer sagt ífornum vísindum:Tekstualiseringen av de Mytologiske Eddadikt. Bergen.

Thorvaldsen, Bernt Øyvind, 2008: Om Prymskviða, tekstlån og tradisjon. Maal og Minne 2008(2): 142-166.

Timonen, Senni, 2004: Minä, tila, tunne: Näkökulmia kalevavamittaiseen kansanlyriikaan. Helsinki.

Urban, Greg, 1986: The Semiotic Functions of Macro-Parallelism in the Sholkeng Origin Myth. In: Native South American Discourse. Ed. J. Sherzer \& G. Urban. Berlin. Pp. 15-57.

Ussing, L. J., S. Birket Smith, Ludv. F. A. Wimmer, Vilh. Thomsen \& Johannes C. H. R. Steenstrup, 1894: Katalog den Arnamagnaanske håndskriftsamling, vol. II. København.

Vésteinn Ólason, 2019: The Codex Regius - A Book and Its History. In: The Codex Regius of the Poetic Edda: Konungsbók Eddkvaða GKS 2365 4to. Reykjavík. Pp. 217-256.

Vésteinn Ólason and Guðvarður Már Gunnlaugsson, eds., 2001: Konungsbók Eddkvaða: Codex Regius: Gl. Kgl. Sml. 2365 4to. Reykjavík. (Íslensk miðalaldahandrit. Manuscripta Islandica Medii Aevii 3.)

Wimmer, Ludv. F. A., ed., 1896: Oldnordisk Laesebog. 5. gennemsete udg. København.

Wimmer, Ludv. F. A., \& Finnur Jónsson, eds., 1891: Håndskriftet Nr. 2365 4to gl. kgl. Samling påå det store kgl. bibliothek $i$ København (Codex regius af den aldre Edda) i fototypisk og diplomatisk gengivelse. København.

Pórdís Edda Jóhannesdóttir, 2011a: Síðustu vísur Sigurdrífumála: Varðveisla og vitnisburður yngri handrita. MA thesis, University of Iceland.

Pórdís Edda Jóhannesdóttir, 2011b: Sigurdrífumál og eyðan í Konungsbók Eddukvaða: Um varðveislu Sigurdrífumála í yngri handritum og útgáfu síðustu vísnanna. Grípla 23: 287-317. 


\section{Summary}

The rise of interest in the orality of eddic poetry has tended to view the preserved corpus as oral poems without considering their transition into writing and its potential implications. The present article is an exploratory study of variation in the ordinal inventories of questions and knowledge in Vafprúðnismál and Grimnismál. Variation in formula usage might reflect individual creativity and a dynamic handling of the poetic system. The two cases in focus, however, show a correlation between the variations and indicators that the expressions or their organization were not ideal. In both cases, indicators in the poem's text suggest that it is a product of oral presentation transcribed by a second individual. A detailed examination of formulae in Vafprúðnismál point to difficulties where a b-line for vocalic alliteration is expected, for which the solutions seem to get worse rather than better, leading to the possibility that the presenter was bored or disinterested. Several features point to difficulties at the beginning of Grimnismál's inventory, while exceptional variation in formula use leads to a possibility that some variation may be linked to the transcriber rather than the presenter. That blunders of presentation have been preserved in both poems rather than revised, either during the initial documentation or in later copying, reflecting ideas of what these texts are in relation to the tradition.

Keywords: eddic poetry, performance, variation, documentation

\section{Frog}

University of Helsinki

Folklore Studies / Department of Cultures

ORCID iD 0000-0001-5967-6281 



\title{
The Change menninir > mennurnir, mennirnir in Icelandic
}

\author{
LASSE MÅRTENSSON
}

\section{Introduction and Aim}

An important aim for future research within historical linguistics and philology is to increase the empirical base on which the research is carried out. Even though a large number of texts in Old Icelandic and Old Swedish is available in printed editions, individual text witnesses may still contain linguistic data that is not accounted for in the edition. Linguistic variants, especially those based in morphology, are often regarded as insignificant from the perspective of textual criticism (see e.g. Haugen 2013: 103 on substantial and accidental variation respectively), and they are therefore often not included in critical editions. A memorable call for publication of morphological variants was raised by Kjartan Ottosson (2001), under the title 'Kven sitt språk ser vi i avskrifter? - eller Éloge de la variante grammaticale'. In many editions of East Norse texts, such variants are actually included (see e.g. the editions of the Revelations of St Birgitta; Andersson 2014), but in order for this variation to be accounted for, data must be collected from the variant apparatus. If the research material is collected from the the main text only, such variants are lost.

A lot of linguistic information is thus still unrecorded and hidden in the handwritten records of the Middle Ages as well as of later periods. The present investigation is the result of linguistic data being discovered that had not been considered in previous research. The change menninir $>$ mennirnir (nom. pl. of maðr) in Icelandic will be interpreted in the light of these data. In the manuscript AM 557 4to $\left(15^{\text {th }}\right.$ century; see further

Mårtensson, Lasse. 2021. The Change menninir > mennurnir, mennirnir in Icelandic.

Scripta Islandica 72: 93-106.

(C) Lasse Mårtensson (CC BY)

DOI: $10.33063 /$ diva-439402 
below), there are occurrences of the form mennurnir, which are not accounted for in the descriptions of the change menninir > mennirnir in the common handbooks (Noreen 1923 etc.).

\section{Previous Views on the Change menninir $>$ mennirnir}

In Icelandic during the Middle Ages, the older form of the nom. pl. definite form of maðr, menninir, is replaced by the form mennirnir, which is the form used also in modern Icelandic. In the oldest period, menninir also had a parallel form, namely menner (although rarely), and the latter form is assumed to be a result of the development of *menn-ner (Noreen 1923: 284). Staffan Fridell (2007: 150) interprets the form menner/mennir as originating from menninir through haplologic syncope. Haplologic syncope is the loss of a vowel between two identical consonants; a few examples are Traland < *prcelaland, Ones <* Onanes and Helland < *Helliland (Hesselman 1948: 68). Björn K. Pórólfsson (1925: 86) dates the change menninir $>$ mennirnir to the $15^{\text {th }}$ century, without specifying the time further. In Oddur Gottskálksson's translation of the New Testament (1540), only the younger form occurs (Jón Helgason 1929: 60). For Norwegian, Didrik Arup Seip (1931: 193) places the same change in the $13^{\text {th }}$ century, i.e. earlier than in Icelandic.

Adolf Noreen (1923: 284) claims that the change from the older form to the younger one was due to the fact that the older definite form was perceived as indefinite (in accordance with $i$-stems in the pl.), and was provided with a new definite article. This explanation makes sense if the point of departure was menner/mennir. On the surface, this form resembles an $i$-stem in the pl., and addition of the definite article -nir would result in mennirnir. On the other hand, it is more difficult to accept this explanation if the form menninir is the point of departure. It should be stressed that menninir is the form that dominated during the $13^{\text {th }}$ and the $14^{\text {th }}$ centuries, and the explanation given by Noreen can therefore not be said to be very convincing. 


\section{The Examples in ONP}

What can be said about the change menninir > mennirnir on the basis of the data available in the excerpts quoted in ONP? In this collection, there are approximately 25 examples of maðr in the nom. pl. definite form. The instances from the $13^{\text {th }}$ century (ca 12 examples) are with one exception rendered menninir. The exception is one instance of the form mennirnir, found in NKS $235 \mathrm{~g}$ 4to (ca 1260-70; ${ }^{1}$ the final $-r$ is left unrepresented). It is believed that this manuscript has Norwegian provenance (ONP, reg., p. 480). Among the instances from the $14^{\text {th }}$ century, it is also mainly the form menninir that is to be found, even though there are exceptions. This is the case both for the beginning of the century (e.g. GKS 2367 4to; ca 1300-50) and the later part of it (e.g. AM 122 a fol; ca 1350-70). In manuscripts from the $16^{\text {th }}$ century, the younger form mennirnir is to be found (e.g. AM 510 4to; ca 1550). There are two examples of mennirnir in AM 230 fol. (ca 1350-1400), in Barlaams ok Josaphats saga. This text has its origin in a Norwegian version of the saga, ${ }^{2}$ but the manuscript itself has Icelandic provenance. It has been assumed that the exemplar to Barlaams ok Josaphats saga in AM 230 fol. was Norwegian (Rindal 2009: 33-34). Thus, the instances of mennirnir in manuscripts older than the $15^{\text {th }}$ century can be expected to be due to Norwegian influence, either directly, because the manuscript is Norwegian (NKS $235 \mathrm{~g} 4$ to), or through influence from the exemplar (AM 230 fol.). As can be seen, the examples from the period 1400-50 are very few, and over all they provide very sparse evidence for conclusions regarding the change menninir $>$ mennirnir. However, among the excerpts in ONP, the three examples representing the form mennurnir are to be found as described in the following section. ${ }^{3}$

\section{The Form mennurnir}

The three examples representing the form mennurnir are all to be found in the manuscript AM 557 4to, sometimes called Skálholtsbók. It is perhaps

\footnotetext{
${ }^{1}$ The datings of manuscripts are taken from ONP, reg., unless otherwise is stated.

${ }^{2}$ Of the West Norse manuscripts containing this saga, only the version in Reykjahólabók (Loth 1969: 97-131) has another origin (Haugen \& Johansson 2009: 28; Rindal 2009: 32).

${ }^{3}$ These forms were briefly discussed by Mårtensson (2007).
} 
best known for being one of the main manuscripts of Gunnlaugs saga ormstungu and Eiríks saga rauða. This manuscript has been used as the main text in several editions, e.g. by Sven B. F. Jansson (1944; Eiríks saga rauða), Louisa Fredrika Tan-Haverhorst (1939; Dámusta saga), Annette Hasle (1967; Hrafns saga Sveinbjarnarsonar), Ólafur Halldórsson (2000; Rognvalds páttr ok Rauðs) Lasse Mårtensson (2013; Karls páttr vesæla) and Veturliði Óskarsson (2019; Hróa páttr heimska). Finnur Jónsson (1916; Gunnlaugs saga ormstungu) does not use this manuscript as the main text, but he discusses it in the introduction. The manuscript also exists in a facsimile edition (Strömbäck 1940). Mårtensson (2011) dates it to 1404-20, and it has probably been produced by two hands.

Two of the examples representing mennurnir are in Karls páttr vesæla, and the remaining one is in Sveinka páttr Steinarssonar, the tale that concludes the manuscript in its present state. This version of Karls páttr has previously been edited by Birgerus Thorlacius (1815) and Mårtensson (2013); this version of Sveinka páttr is still unedited. The examples are the following:

1. "mennvrner" (46v:24; Karls páttr)

2. "mennvrnir" (47r:2; Karls páttr)

3. "mennvrnir" (48v:18; Sveinka páttr)

The fact that there are three examples, all of which render the same word form, makes it unlikely that they are to be interpreted as scribal errors or misinterpretations of the exemplar by the scribe. It should also be noted that examples rendering the forms menninir or mennirnir are lacking in AM 557 4to; the nom. pl. definite form of maðr only occurs in these three instances.

In order to determine how to interpret these examples we must investigate how the scribe rendered unstressed $u r$ and $r$. The scribe of the current pages in AM 557 4to definitely used the epenthetic vowel [u] in his pronunciation. On the pages containing Karls páttr vesæla and Sveinka páttr Steinarssonar, however, this vowel is never represented (e.g. "madr" 47r:27), and the tendency is the same in the rest of the manuscript (even though there are a few deviating examples, see below). On the other hand, there are many instances of so called reversed spelling, where the original ending -ur is rendered with "r" (e.g. "dottr" dóttur 45v:2; "favdr" foður 46v:9; "fodr" foður 46v:16). The reversed spellings are not used in all cases where $u r$ occurs. The pronoun nokkurr/nokkurr gives an indication of what orthographic principle the scribe has followed. In two-syllable 
forms, e.g. masc. sing. (examples 1, 3 and 4) and neut. pl. (example 2), only reversed spellings are used:

1. "sidr nỏckr" (4r:12)

2. "nockr rad" (45v:20)

3. "nockr madr" (46r:23)

4. "batr nockr" (48r:1)

Of the three-syllable forms, the following examples are to be found on the pages produced by the same scribe as the one who produced the examples above:

1. "nockvrv" (47v:9)

2. "nockvrir" (47v:10)

Here, as can be seen, $u r$ has been represented. ${ }^{4}$ To these cases, one example of a represented epenthetic vowel can be added (not in Karls páttr or Sveinka páttr, but by the same scribe that has produced these texts):

$$
\text { "brvdvrin" (9v:4; Gunnlaugs saga) }
$$

These examples show us the orthographic tendency that the scribe seems to have followed. No distinction is made between the original endings $-u r$ and $-r$; in some cases, both original $[\mathrm{u}]$ and the epenthetic vowel $[\mathrm{u}]$ are left without representation ("fodr" and "madr" respectively). On the other hand, in some cases both the epenthetic vowel and original [u] are represented ("brvdvrin" and "nockvrir" respectively). The scribe appears to have left the pronounced $[\mathrm{u}]$ without representation in the final syllable of a word. On the other hand, if an article follows $-u r$ or $-r,[u]$ is in most cases represented. ${ }^{5}$

If this rule is applied to the spellings "mennvrner/ mennvrnir/ mennvrnir", it becomes clear that "vr" in this position, i.e. unstressed position but not in the final syllable, is used for the phonological sequence [ur] (originating in either $-u r$ or $-r$ ). The interpretation of these examples

\footnotetext{
${ }^{4}$ The forms of this pronoun, the ending of which began on a vowel (e.g. the ones above), were later contracted into two-syllable forms as the [u] was dropped. However, such forms did not become common until the later part of the $15^{\text {th }}$ century (Hreinn Benediktsson 196162: 35-36 and Stefán Karlsson 1989: 24; cf. Björn K. Pórólfsson 1925: 49, who puts the date approximately 100 years earlier through a wrong dating of AM $180 \mathrm{~b}$ fol.; see Hreinn Benediktsson 1961-62: 35).

${ }^{5}$ It should be stressed that there are exceptions to this rule in AM 557 4to, also by the hand that produced Karls páttr and Sveinka páttr. One example is "kỏnrnar" (konurnar, 10v:17; Gunnlaugs saga).
} 
must be that the scribe has perceived this word form as mennurnir. It is less likely that the examples are the result of wrongly expanded abbreviations. If spellings representing the word form mennirnir had been in the exemplar, with the sequence [ir] in the corresponding position abbreviated, one would have expected the so called er-abbreviation or superlinear " $i$ ". None of these abbreviations are so similar to the urabbreviation that a scribe should mix them up, and especially not three times in different passages. Furthermore, the lemma maðr is frequent in the everyday language. Statistics for the spoken language of the Middle Ages can of course not be produced, but we can at least conclude that it was very frequent in the written language, with no less than 1288 occurrences in the collection of examples in ONP. The three examples of this spelling are also to be found in uncomplicated contexts, and the scribe cannot have been in any doubt as to what word form that was intended. It is therefore likely that the three examples in AM 557 4to represent genuine forms of the word in question, and that the scribe of this manuscript perceived the nom. pl. definite form of maðr as mennurnir.

As there are no other examples of this form among the excerpts of ONP, and as it has left no trace in modern Icelandic, it is impossible to make any assumption regarding how widely used it was. It is of course possible that it was confined to one individual, i.e. the scribe of the current pages in AM 5574 to, but is more likely that it was more widely spread. As seen from the excerpts of ONP, the examples of the nom. pl. definite form of maðr are very few indeed. What variants existed and where and when they were used cannot be deduced on the basis of the data available in ONP.

\section{Mennirnir and mennurnir as Morphological Reinterpretations of menninir}

Having not only mennirnir but also mennurnir to account for, another explanation than that given by Noreen (see above) ought to be sought. For instance, we may ask how the forms mennirnir and mennurnir are related to each other? Is mennurnir an until now non-registered step between menninir and mennirnir? Or is it a parallel form to mennirnir (also nonregistered), which disappeared as mennirnir grew more common? The first explanation, i.e. that it is a middle step between menninir and mennirnir, appears less likely. According to such an explanation, mennirnir would 
have originated from mennurnir, i.e. menninir $>$ mennurnir $>$ mennirnir . Such a development is difficult to explain, at least from a phonological perspective, as there is no reason for the change $[u]>[i]$ in this position. Instead it is more likely that the two forms were parallel, existing for a period at the same time. In the end, mennirnir became dominant, whereas mennurnir disappeared, and as far as we know leaving no other trace than the three examples above.

The solution proposed here is that both mennurnir and mennirnir are analogical forms, representing two different morphological reinterpretations of the form menninir. The origin of this reinterpretation is that a form menninir in the nom. pl. of a masculine word with a definite article is extremely rare. The word maðr belongs to the masculine one-syllabic stems, and the only word that is declined in the same way is nagl (Noreen 1923: 283-284). A masc. nom. pl. form without any plural ending is thus very uncommon, and a definite form with only -nir (menninir) has very few parallells.

Arguably, an explanation for the form mennirnir is that it constitutes the result of an analogical change from the extremely uncommon form menninir to the form of the $i$ - and the $u$-stems nom. pl. in the definite form (cf. gestirnir and staðirnir; birnirnir and kettirnir). These classes of nouns are frequent, especially the $i$-stems, offering very frequent models. According to this line of argument, the form mennurnir also comprises an analogic form, modelled not on the $i$-stems but on the nom. pl. of masculine words with original $-r$ in the plural, especially one-syllabic consonant stems of the type fótr/foetr, fingr/fingr, vetr/vetr (the type to which maðr in fact belongs). With an epenthetic vowel and the definite article, the result is urnir in the nom. pl. definite form of these words. Probably the form in AM 5574 to is analogical according to this pattern, and this form probably existed parallel to mennirnir for a period of time (though it is unclear how common it was) but then disappeared. If the explanation given above is correct, it is not surprising that mennirnir became dominant over mennurnir, as the $i$-stems provided a much more frequently occurring pattern than the one-syllabic consonant stems. The $i$-stems constitute one of the really large noun classes, whereas the one-syllabic consonant stems are much less numerous. For the masculine one-syllabic consonant stems, Wessén (1958: 69-70) registers only five such nouns, fótr, fingr, vetr, nagl and maðr (and in addition a few names of peoples), whereas the feminine ones are rather more numerous. See also Haugen (2006: 119-120).

One might ask, though, why the same change did not take place with 
the indefinite form, i.e. menn $>*$ mennir? As pointed out above, the lemma maðr was very frequent and as a result, fairly resistant to change. The difference between the definite and the indefinite form is that former has an element, the article -inir, that triggers the change. The word form menn with this article, rendering a word form menninir, comes very close to the pattern of gestirnir etc., and the addition of an $r$-component is a the minimal change resulting in a more frequent form.

One final remark regarding mennurnir should be made. The form mennr/meðr in the nom. pl. existed at an early stage (Noreen 1923: 284), and with an epenthetic vowel the result would be mennurnir. However, with respect to the chronological distribution of the preserved examples of this form, it is not likely that it is here that the origin of the form in AM 5574 to is to be found, as it appears to be absent during the $13^{\text {th }}$ and the $14^{\text {th }}$ centuries, and then occurs in a few instances in the beginning of the $15^{\text {th }}$ century. Instead, as stated above, it is more probable that it has arisen at a later stage, unrelated to the older form.

To shed additional light on the change under discussion, the Old Swedish counterpart will be presented. The Old Swedish form in the nom. sing. is often rendered maper, the $b$ representing a voiced fricative and the $e$ the epenthetic vowel. Of course, as in Old Icelandic, it belongs to the one-syllabic declension, and the plural form without the definite article is mann. With the definite article, the normalized form usually given is manninir (see maper in Schlyter and Söderwall). The form of the definite article in the masc. pl. nom. is given in Noreen (1904: 405) given as -(e)ne(r) and in Wessén (1968: 119) -ni(r).

As in Old Icelandic, there are very few words that are declined in the same way as maper; Wessén (1968: 99) mentions only spander that constitutes a real correspondent, with the plural form spann (spän in Wessén), and Noreen (1904: 327) adds that finger occasionally follows this pattern, and perhaps also êster 'estonian'. From the perspective of the form in the nom. pl., however, finger differs from maper and spander in that it has -er in the plural (finger), thus resembling the more frequent nom. pl. forms of the masculine words. This makes the plural pattern of maper very uncommon, having only one parallel. In Swedish, the modern form in the pl. in the definite form is männen. The form of the article attached to männ, -en, is the common form of the neutral words.

The development mannini $(r)>$ mannin is explained in Wessén (1968: 81) in terms of the unstressed position of the article. He states that a vowel in an ending in absolute unstressed position ("absolut trycksvag 
stavelse") is dropped, and this takes place around 1500. The words that fullfil the criteria for this development are three-syllable word forms with acute accent, and the examples given by Wessén (loc.cit.) are: fötrine $>$ fötren, fädhrine > fädhren, nätrina > nättren and männine > männen. Of these, only männen has survived in the language until today, at least as an unmarked form. Noreen (1904: 146) mentions the same change ("apokope im absoluten auslaut") and gives the example bøndren, but he claims that it has taken place only in certain dialects.

It is of course possible that these forms should be explained phonologically as loss of the final vowel due to the unstressed position. Another explanation, however, is that they actually represent analogical forms. The definite article -in/-en is the one used in the neut.pl., e.g. barnin/barnen, and as such it is of course very common. The plural form mann shares the feature of the plural forms of the neuter nouns in that it has no ending, and an analogic transfer of the article would therefore not be surprising.

A check in the texts in the Fornsvenska textbanken only yields threesyllable forms of the investigated word form, mainly monnene etc. but also a number of occurrences of mannena (in the nom.). No examples of the two-syllable form, monnen etc., are found, even though there are manuscripts from the $16^{\text {th }}$ century among those used for editions there. One can mention Cod. Ups. C 61 and Cod. Holm. A 1, and also in these, only three-syllable forms are to be found. To judge from this evidence, it appears that the change monnene $>$ mannen in Swedish is younger than the change menninir > mennirnir in Icelandic.

In this perspective, it is possible to assume that both Swedish männen and Icelandic mennirnir represent analogic forms, where the very uncommon form menninir/mannini( $r$ ) have changed to more common patterns. The different prerequisites in the two languages have led to the form menninir/mannini( $r$ ) joining different classes. In Old Swedish, there was a common loss of [r] in the plural endings - $a r$,-ir etc., especially when the definite article was attached (hoestane etc.). This means that a structure -irnir was not, as in Icelandic, very common, especially compared to the very common -in/-en on all the neuter nouns in the pl. definite form.

Hreinn Benediktsson (1959: 69-70) draws a line between phonemic and morphemic analogic changes, and he prefers to call the latter type analogic transformations (áhrifsummyndanir). The process in this type of change is that a certain morpheme is exchanged for another one, usually a frequent morpheme taking the place of a more infrequent one. An example given by Hreinn Benediktsson (loc. cit.) is when the endings 
of adjectives in masc. sing. acc. on the $j a$ - and the $w a$-stems (-jan and -van respectively) are exchanged for the corresponding ending of the very frequent $a$-stems (-an). This results in the changes sekjan $>$ sekan and glöggvan > glöggan, which are the results of exchange of morphemes, not phonological processes. This describes well the process that has created the form mennirnir, as the change cannot be accounted for in phonological terms. Instead, the form has originated through the form menninir being transformed in accordance with a high-frequency morphological structure. Hreinn Benediktsson does not mention this change in his overview over a number of analogical changes in Icelandic, but it must be stressed that it is confined to one specific word. It is not a part of a pattern visible in a great number of words, nor could it be expected to be, as the point of departure, menninir, represent a very uncommon structure.

For later Icelandic, a so-called $n$-pronunciation in Icelandic has been identified, which could be of relevance for the change dealt with here if it existed before the emergence of the form mennirnir. The $n$-pronunciation consists of a loss of the first $r$-component in the endings -arnir,-irnir and -urnir (Björn Guðfinnsson 1964: 75-76; Kristján Árnason 2005: 409; the same feature is also present in modern spoken Faroese, see Höskuldur Thráinsson et al. 2012: 55). This change leads to -irnir being pronounced [inir],i.e. the same as the ending -inir in menninir. If this pronunciation was of medieval origin, the merger of -inir and -irnir could have been the result of a change in the direction-irnir >-inir, and then, when the pronunciation including the [r], i.e. [irnir], gained ground, it also brought with it menninir $>$ mennirnir. However, the time of origin of this pronunciation is not clear, and it seems that it is not to be found in medieval sources. It has primarily been observed in investigations of spoken language (e.g. by Björn Guðfinnsson 1964), and it has rarely left traces in the written language even though there are occurrences from the $18^{\text {th }}$ century (Jón Helgason 1972: 359). Still, the weak evidence for it during the Middle Ages makes this explanation less likely to the origin of mennirnir.

\section{Conclusion}

The definite form of maðr in the nom. pl., mennirnir, is the result of a morphological reinterpretation, where the very infrequent and almost isolated form menninir formally has joined the very frequent category of 
the $i$-stems (and the $u$-stems). Another morphologically reinterpreted form also existed, mennurnir, which joined the one-syllable stems of the type fótr (fótur). As the latter form has not survived into modern Icelandic, and is preserved only in three examples in one single manuscript, it is very difficult to say how widely it was used. As noted above, however, the excerpts in ONP of the word form in question for the whole $15^{\text {th }}$ century are few. It is difficult to follow this change in the written sources of this period. If the variant mennurnir was actually used more widely than by just one individual, it is possible that it was used regionally on the north of Iceland (the probable place of provenance for AM 557 4to; Mårtensson 2011). Regarding the time of the change menninir > mennirnir, it appears that it occurred during the $15^{\text {th }}$ century. The form mennurnir existed during the same century, at least in the beginning of this century, as AM 557 4to was produced at this time.

As shown above, a similar type of reinterpretation probably took place in Old Swedish, but the result was not the same. Here, the reinterpretation resulted in a form that coincided with the definite form of neuter words in the nom. and the acc. (barnin/barnen; mannin/mannen). This change, however, seems to have taken place at a later stage than the change in Icelandic. Also in the Swedish manuscripts from the late Middle Ages, even in those from the early $16^{\text {th }}$ century, the older form mannene (sometimes mannena) is the one commonly used.

\section{Literature}

Andersson, Roger, 2014: Heliga Birgittas texter på fornsvenska. Birgittas uppenbarelser. Bok 1. Editiones 6. Runica et Mediævalia. Stockholm.

Birgerus Thorlacius, 1815: Páttr af Karli Vesala. Res gestæ Caroli infortunati. Textus Islandicus nunc primum editus, latine versus et præfatiuncula instructus. In: Prolusiones et opuscula academica, argumenti maxime philologici 3 . Havniæ (Copenhagen). Pp. 309-57.

Björn Guðfinnsson, 1964: Um íslenzkan framburð. Mállýzkur 2. Ólafur M. Ólafsson and Óskar Ó. Halldórsson prepared the author's material for print. Ed. Steingrímur J. Porsteinsson. Studia Islandica 23. Heimspekideild Háskóla Íslands og Bókaútgáfa menningarsjóðs. Reykjavík.

Björn K. Pórólfsson, 1925: Um íslenskar orðmyndir á 14. og 15. öld og breytingar peirra úr fornmálinu. Með viðauka um nýjungar í orðmyndum á 16. öld og síðar. Reykjavík. New print 1987 in the series Rit um íslenska málfræði 2. Málvísindastofnun Háskóla Íslands. 
Finnur Jónsson, 1916: Gunnlaugs saga ormstungu. Samfund til udgivelse af gammel nordisk litteratur 42. København.

Finnur Jónsson, 1928-32: Morkinskinna. Samfund til udgivelse af gammel nordisk litteratur 53. København.

Fornsvenska textbanken: https://project2.sol.lu.se/fornsvenska/ Ed. Lars-Olov Delsing.

Fridell, Staffan, 2007: Recension av Språk och lag. In: Namn och bygd. Tidskrift för nordisk ortnamnsforskning 95. Pp. 149-50.

Hasle, Annette, 1967: Hrafns saga Sveinbjarnarsonar. B-redaktionen. Editiones Arnamagnæanæ B:25. Ejnar Munksgaard. København.

Haugen, Odd Einar, 2006: Grunnbok i norrønt språk. 4 ed. Gyldendal Norsk Forlag AS. Oslo.

Haugen, Odd Einar, 2013: Tekstkritikk og tekstfilologi. In: Handbok i norrøn filologi. Ed. Odd Einar Haugen. 2 ed. Fagbokforlaget. Bergen. Pp. 76-126.

Haugen, Odd Einar \& Karl G. Johansson, 2009: De nordiske versjonene av Barlaam-legenden. In: Barlaam i nord. Legenden om Barlaam och Josaphat i den nordiska medeltidslitteraturen. Ed. Karl G. Johansson \& Maria Arvidsson. Bibliotheca Nordica 1. Novus forlag. Oslo. Pp. 11-29.

Hesselman, Bengt, 1948: Huvudlinjer i nordisk språkhistoria 1. Nordisk kultur 3. Bonnier. Stockholm.

Hreinn Benediktsson, 1959: Nokkur dæmi um áhrifsbreytingar í íslensku. In: Íslenzk tunga - Lingua Islandica 1. Reykjavík. Pp. 55-70.

Hreinn Benediktsson, 1961-62: Óákv. forn. nokkur, nokkuð. In: Íslenzk tunga 3. Tímarit um íslenzka og almenna málfræði. Pp. 7-83.

Höskuldur Thráinsson, Hjalmar P. Petersen, Jógvan í Lon Jacobsen and Zakaris Svabo Hansen, 2012: Faroese. An Overview and Reference Grammar. 2nd ed. Fróðskapur. Tórshavn/Málvísindastofnun Háskóla Íslands. Reykjavík.

Jansson, Sven B. F., 1945: Sagorna om Vinland 1. Handskrifterna till Erik den rödes saga. Kungl. Vitterhets Historie och Antikvitets Akademiens Handlingar 60:1. Stockholm.

Jón Helgason, 1929: Málið á Nýja Testamenti Odds Gottskálkssonar. Safn Fræðafjelagsins um Ísland og Íslendinga 7. Reykjavík. New print 1999 in the series Rit um íslenska málfræði 4. Málvísindastofnun Háskóla Íslands.

Jón Helgason, 1972: Om islandsk $n$ og $n n$ i tryksvag udlyd. In: Opuscula 4. Bibliotheca Arnamagnæana 30. Pp. 356-360.

Kristján Árnason, 2005: Hljóð. Handbók um hljóðfræði og hljóðkerfisfræði. Coauthor Jörgen Pind. Íslensk tunga 1. Almenna bókafélagið. Reykjavík.

Loth, Agnete, 1969: Reykjahólabók. Islandske helgenlegender. Editiones Arnamagnæanæ A:15. Ejnar Munksgaard. København.

Mårtensson, Lasse, 2007: En ovanlig ordform i den isländska handskriften AM 557 4to. In: Språk och lag. En vänskrift till Per-Axel Wiktorsson. Red. Johnny Hagberg. Skara. Pp. 41-42.

Mårtensson, Lasse, 2011: Studier i AM 557 4to. Kodikologisk, grafonomisk och 
ortografisk undersökning av en isländsk sammelhandskrift från 1400-talet. Rit 80. Stofnun Árna Magnússonar í íslenskum fræðum. Reykjavík.

Mårtensson, Lasse, 2013: Den fristående redaktionen av Karls páttr vesæla. Undersökning, utgåva och översättning. Sällskapet Runica et Mediævalia. Editiones 5. Stockholm.

Noreen, Adolf, 1923: Altisländische und altnorwegische grammatik (laut- und flexionslehre) unter berücksichtigung des urnordischen. 4. vollständig umgearbeitete aufl. Sammlung kurzer grammatiken germanischer dialekte 4. Altnordische grammatik 1. Verlag von Max Niemeyer. Halle (Saale).

Ólafur Halldórsson, 2000: Ólafs saga Tryggvasonar en mesta 3. Editiones Arnamagnæanæ A:3. C. A. Reitzels forlag. København.

ONP, reg. = Ordbog over det norrøne prosasprog/Dictionary of Old Norse Prose. Registre 1989. Den Arnamagnæanske Kommission. København.

ONP's collection of excerpts. http://dataonp.hum.ku.dk/index.html

Rindal, Magnus, 2009: Barlaams ok Josaphats saga i det norske litterære miljøet. In: Barlaam i nord. Legenden om Barlaam och Josaphat i den nordiska medeltidslitteraturen. Eds. Karl G. Johansson \& Maria Arvidsson. Bibliotheca Nordica 1. Novus forlag. Oslo. Pp. 31-45.

Schlyter = Corpus iuris sueo-gotorum antiqui. Samling af Sweriges gamla lagar, på kongl. maj:ts nådigste befallning utgifven af d. C.J. Schlyter. Vol. 13. Glossarium ad Corpus iuris Sueo-Gotorum antiqui. $1877=$ Ordbok till Samlingen af Sweriges gamla lagar. Berlingska boktryckeriet, C. W. K. Gleerup. Lund.

Seip, Didrik Arup, 1931: Norsk språkhistorie til omkring 1370. Aschehoug. Oslo. Stefán Karlsson, 1989: Tungan. In: Íslensk pjóðmenning 6. Munnmenntir og bókmenning. Reykjavík. Pp. 3-54. Also in Stafkrókar. Rit Stofnunar Árna Magnússonar 49. 2000. Reykjavík.

Strömbäck, Dag, 1940: The Arna-Magnæan Manuscript AM 557 4to, containing inter alia the History of the first Discovery of America. Corpus Codicum Islandicorum Medii Aevi 13. Copenhagen. Ejnar Munksgaard.

Söderwall = K. F. Söderwall et al. Ordbok över svenska medeltidsspråket. 18841973. Samlingar utgivna av Svenska fornskriftsällskapet 1:27 \& 54. Svenska fornskriftsällskapet. Lund.

Tan-Haverhorst, Louisa Fredrika, 1939: Pjalar Jóns saga. Dámusta saga. 1. Teksten. Haarlem.

Wessén, Elias, 1958: Isländsk grammatik. Scandinavian university books. Svenska bokförlaget. Stockholm.

Veturliði Óskarsson, 2019: Slysa-Hróa saga. In: Opuscula 17. Pp. 1-97. 


\begin{abstract}
This article discusses a word form that has been unnoticed by previous research, namely mennurnir, nom. pl. of maður with definite article. In the dictionary excerpts of ONP (Dictionary of Old Norse Prose), there are three examples of this word form, all of which are in the $15^{\text {th }}$ century manuscript AM 557 4to, sometimes called Skálholtsbók. An analysis is made of the scribe's representation of -ur and $-r$ respectively (these two having run together in his speech). It is clear that he cannot have had any other word form in mind when writing these examples, and furthermore, they were not the result of scribal errors.

There are only few examples of maður in nom. pl. with the definite article among the dictionary slips, and it is difficult to get a good picture of the development of the word form at the time in question. The author argues that the form mennurnir actually was in use, as it is unlikely with a language feature represented by one person only. The form probably originated as a result of a morphological reinterpretation of the form menninir, with the consonantal stems like vetr and fingr as a pattern.
\end{abstract}

Keywords: Morphology, linguistic change, Old Icelandic

Lasse Mårtensson

Uppsala universitet

Institutionen för nordiska språk

ORCID iD 0000-0001-5072-4961 


\title{
Läsning för folket? \\ Gunnlaugs saga ormstungu i skandinaviska nyöversättningar: Hur? För vem? Varför?
}

\author{
MARTIN RINGMAR
}

\section{Inledning}

År 2014 publicerades samtliga islänningasagor i dansk, norsk och svensk nyöversättning. Förlaga var den modernortografiska Íslendinga sögur som förlaget Svart á hvítu gav ut i tre band 1987. Denna utgåva hade då redan legat till grund för en engelsk översättning (1997) på förlaget Leifur Eiríksson Publishing, grundat för detta ändamål av Jóhann Sigurðsson från Svart á hvítu. Samme man startade sedan Saga forlag för de skandinaviska utgåvorna, vilka är i fem delar liksom den engelska och i varierande grad återanvänder dess paratexter. Fem år efter utgivandet, i september 2019, ordnades en konferens i Reykjavik som bl.a. skulle summera hur de skandinaviska nyöversättningarna tagits emot, och föreliggande artikel bygger på ett föredrag där. ${ }^{1}$

De skandinaviska utgåvorna är i påkostade band och har omfattande inledande och avslutande förklarande texter: i $S v$ totalt 112 sidor, i $D a$ omkring 130 och i No cirka $80 .^{2}$ Alla tre inleds med en hälsning från

\footnotetext{
1 "De islandske sagaer i en ny udgave på dansk, norsk, svensk og islandsk" (Reykjavik 6-7/9 2019). Saga forlag gav även ut sagorna i original i fembandsformat år 2018, vilket delvis bekostades av Alltinget med anledning av Islands 100 år som suverän nation (https:// stundin.is/blogg/thorbergur-thorsson/ny-utgafa-af-islendingasogunum; läst 29/8 2019).

${ }^{2}$ Förkortningarna $D a$, No och $S v$ syftar dels på de tre utgåvorna generellt, dels, om sidhänvisning finns, på band I i respektive utgåva; Is syftar på förlagan (1987) och Eng på
}

Ringmar, Martin. 2021. Läsning för folket? Gunnlaugs saga ormstungu i skandinaviska nyöversättningar: Hur? För vem? Varför?

Scripta Islandica 72: 107-126.

(C) Martin Ringmar (CC BY)

DOI: $10.33063 /$ diva-439403 
respektive regent, av vilka drottning Margrethe är personligast och bl.a. delger läsarna att "[f]ra en ung alder har sagaerna begejstret mig" (något sådant säger varken Harald eller Carl Gustaf). Totalkostnad för de tre boxarna - i cirka 2000 exemplar var - lär ha varit drygt 15 miljoner svenska kronor (Edlund 2015: 457), något som till stor del bestritts av olika kulturfrämjande institutioner och fonder. Dessutom har Islands regering köpt in hundratals exemplar som skänkts till bibliotek i Norden. ${ }^{3}$

Att förlaget fått kostnaderna täckta av mecenater och att det dessutom är baserat på Island har möjligen haft menlig inverkan på försäljningen utomlands:

Försäljningsmässigt har den svenska översättningen varit ett fiasko. Saga forlag, det isländska förlag, som står bakom projektet har enbart distribuerat böckerna till Sverige genom försäljning via den egna webbplatsen. [...] I Norge och Danmark har försäljningen gått betydligt bättre. Flera av de översättare som arbetade med den svenska utgåvan är mycket missnöjda med att förlaget enbart koncentrerat sig på att få ut verket utan att till synes ha haft några som helst tankar på hur det skulle kunna nå svenska lärare [sic! ]. ${ }^{4}$

Och mycket tyder på att försäljningen gått bättre i grannländerna än i Sverige, inte minst då i Danmark där dessutom ett urval publicerats i två lätthanterligare volymer på Gyldendals 2017-18 (Islændingesagaerne: et udvalg i ny oversættelse). ${ }^{5}$ Det har vidare varit tal om att de skandinaviska nyöversättningarna ska bli fritt tillgängliga digitalt, men när tycks ännu oklart.

Till konferensen 2019 hade jag blivit ombedd att jämföra översättningarna av en kortare saga som innehåller poesi, och valet föll på Gunnlaugs saga ormstungu. Så avsikten är här dels att ge en beskrivning av de skandinaviska utgåvorna generellt, dels att jämföra de tre versionerna av

den engelska utgåvan från 1997. Den svenska utgåvan har utförligt recenserats av LarsErik Edlund $(2015,2017)$.

${ }^{3}$ I Sverige har varje kommunbibliotek fått minst ett av totalt 390 gåvoexemplar (e-brev från Kristinn Jóhannesson 30/9 2019). Saga forlag har dessutom skänkt varje översättare en komplett fembandsbox, även till dem vilka - i likhet med artikelförfattaren - enbart översatt ett par kortare sagor. Rimligtvis har sponsorpengarna bidragit till att möjliggöra denna generositet.

4 https://www.islandsbloggen.com/2018/01/island-skanker-sverige-islanningasagor.html (läst 29/8 2019).

${ }^{5}$ Den danska utgåvans stora genomslag, försäljningsmässigt och medialt, bekräftades av flera föredrag under konferensen i Reykjavik i september 2019. 
Gunnlaugs saga, inbördes och i relation till förlagan, med särskilt fokus på namnskick, ordförråd, tempusbruk och återgivandet av poesin.

\section{1 Översättarna av Gunnlaugs saga}

Av de tre skandinaviska översättarna av Gunnlaugs saga (GS) var den danske, Rolf Stavnem (f. 1965), den mest erfarne med ett 15-tal översatta böcker från isländska, gammal och ny. Han är en av de centrala översättarna inom $D a$ med fem sagor (totalt 367 sidor) och han fungerade dessutom som poesigranskare för hela utgåvan. Den svenske översättaren, Mats Malm (f. 1964), hade enbart tre tidigare översättningar i bagaget - samtliga från fornisländska - men som professor i litteraturvetenskap och numera ledamot i Svenska Akademien besitter han avsevärt kulturellt kapital; han har dessutom kopplingar till $S v$-redaktörerna via Göteborgs universitet. Förutom GS har han översatt ytterligare två sagor i $S v(93 \mathrm{~s}$. totalt). Arnhild Mindrebø (f. 1941) studerade på Island läsåret 1963-64 och arbetade sedan som gymnasielärare i norska och tyska. Trots obetydlig tidigare erfarenhet blev hon uppmanad av sin f.d. elev, No-redaktören Jon Gunnar Jørgensen, att översätta för No vilket resulterade i sju sagor samt sex tåtar eller kortsagor (totalt $322 \mathrm{~s}$.).

\subsection{Generella översättningsstrategier}

De skandinaviska nyöversättningarna är kollektiva projekt. I $D a$ leddes 14 översättare av en redaktör, medan $S v$ :s tre redaktörer styrde hela 24 översättare, och i Norge arbetade totalt 19 översättare under en redaktör för respektive nynorska och bokmål. ${ }^{6}$ Översättarnas insatser varierade naturligtvis, från en enda tåt på några sidor till flera längre sagor; exempelvis står Rolf Stavnem tillsammans med två andra översättare för mer än halva sidantalet i $D a$. Dessutom har i alla tre länderna skönlitterärara författare utan kunskaper i originalspråket fungerat som "kvalificerade läsare" av måltexterna.

Som i alla projekt av det här slaget - man kan jämföra med bibelöversättning - blir slutprodukten i skiftande grad en kompromiss. Den danska redaktören, Annette Lassen, säger sig ha eftersträvat en balans mellan

\footnotetext{
${ }^{6}$ Bokmålsredaktören Jon Gunnar Jørgensen (muntligen 6/9 2019) förstod det som att Saga forlag egentligen hade föredragit enbart bokmål, något som dock hade varit ogörligt givet projektets omfattning och tidsramar (av totalt 40 sagor är 23 på nynorska). Det lär f.ö. vara sällsynt att de två skriftspråken samsas inom samma bokpärmar på detta sätt.
} 
översättarens stilvilja och "en nogenlunde homogen og konsekvent gengivelse af originalteksterne" (Da: L). Lassen är för övrigt den av redaktörerna som utförligast diskuterar typiska problem vid översättning av isländska sagor. Tydliga skillnader finns här mellan redaktionerna, där framförallt $S v$ skiljer ut sig beträffande namn och historiskt presens, medan alla tre divergerar i diktöversättningarna.

\section{Gunnlaugs saga i översättning}

Den första översättningen av Gunnlaugs saga ormstungu kom ut 1775 i Köpenhamn i en parallellspråklig praktutgåva på isländska och latin, vilken då var den första publicerade kompletta översättningen av en islänningasaga överhuvudtaget (Lassen 2014: 58f). Sedan dess har den blivit en av de mest spridda sagorna, något som ingen utgivare försummar att påpeka: "Gunnlaug ormstungas saga är - om översättningar till olika språk medräknas - den isländska bok, som blivit tryckt flest gånger" (Alving 1938: VIII). Enligt databasen Pýðingar íslenskra miðaldabókmennta har den översatts till totalt 25 språk, enbart överträffad av Njáls saga med 26. ${ }^{7}$ Vad gäller antalet utgåvor och upplagor innehar dock troligen GS fortfarande förstaplatsen, säkert mycket tack vare sitt behändiga format (cirka 30 trycksidor).

Den begränsade längden gör GS lämplig som introduktion till genren islänningasagor, vilket ett stort antal skolutgåvor vittnar om, t.ex. Modersmålslärarnas förenings 1930 (och senare) i översättning av Josua Mjöberg. Troligen har även triangeldramat mellan skalderna Gunnlaug och Hrafn och Helga den fagra förmodats intressera "det nu uppväxande släktet" som därur kunnat hämta "livskraft nog att friska upp sig med" (Bååth 1910: 3). GS har dessutom i många länder kommit ut i original med översatt parallelltext eller med rikliga förklaringar, så t.ex. i England:

"Gunnlaugssaga" has an interesting theme presented in a prose style which, while not offering any grave linguistic difficulties, is of high literary merit; and for these reasons the saga is well suited to fulfil the purpose of this book, namely, to provide a simple and useful reading-book for English-speaking students of Old Norse. (Small 1935: 5)

\footnotetext{
${ }^{7}$ https://sagas.landsbokasafn.is/ (sökningen utförd 31/8 2019).
} 
Det finns många äldre översättningar av GS till de skandinaviska språken, av vilka vissa återutgivits moderniserade, liksom ett flertal bearbetningar för barn och ungdom som i Kata Dalströms Nordiska hjältesagor för ungdom från 1889 eller Erik Hjorth Nielsens Gunløg Ormstunga - en billedsaga från 1994, vilken även översatts till svenska. GS har vidare utgjort grundlag för ett par skandinaviska dramatiseringar liksom för en opera (Gunnlögs saga) skriven 1897 av Preben Nodermann, sedermera domkyrkoorganist i Lund. Operan trycktes i samband med ett konsertant framförande 1927 men väntar ännu på sitt sceniska uruppförande (Bengtsson 1988: 33f).

De svenska översättningarna av GS delas naturligt in i tre perioder: 1856-1872 (3 översättningar), 1930-1962 (3) samt 2014 (1). Under 1800-talet anpassades huvudpersonens namn till Gunlög/Gunnlög men från 1930 heter han Gunnlaug. ${ }^{8}$ Att 1900-talsöversättningarna, vilka för övrigt försvenskar namnen, behåller originaldiftongen i titelnamnet kan bero på att kvinnonamnet Gunlög hade vunnit i popularitet efter sekelskiftet 1900. Den danska motsvarigheten (Gunløg) är så gott som okänd som kvinnonamn varför anpassningen av hjältens namn är oproblematisk där. I Norge åter är kvinnonamnet Gunnlaug ungefär lika frekvent som Gunlög i Sverige, men någon differentiering är inte möjlig då norskan behållit diftongen 'au'. På Island är för övrigt mansnamnet Gunnlaugur betydligt vanligare än kvinnonamnet Gunnlaug även om det senare förvisso förekommer.'

\section{De skandinaviska nyöversättningarna}

\subsection{Namnformer}

Isländska egennamn är notoriskt problematiska vid översättning där "diplomatarisk återgivning av källspråkets form utgör den ena ytterligheten, och den andra innebär att alla namnformer byts ut mot ekvivalenter som finns i målspråket" (Hannesdóttir 1998: 70). T.ex. skulle ett namn

${ }^{8}$ Två av 1800-talsöversättningarna samt $S v$ skriver binamnet utan 's' (Ormtunga), de övriga Ormstunga.

${ }^{9}$ Uppgifter om antalet bärare av namnet Gunlög (etc.) har hämtats på: https://www.scb.se; https://www.dst.dk; https://www.ssb.no; https://www.hagstofa.is/talnaefni/ibuar/faeddirog-danir/nofn (sökningarna gjorda 30/8 2019). 
som Puríður rent teoretiskt kunna återges på 33 olika sätt mellan ytterpunkterna Puríður och Turid (Ringmar 2011). I regel har namn anpassats mer i översättningar av fornsagorna än av modern litteratur, vilket bl.a. kan bero på sagaöversättningarnas sekelgamla tradition (tidigare torde även trycktekniska begränsningar ha spelat in). I motsats till $D a / N o$ bryter $S v$ med denna tradition och inför diplomatarisk namnåtergivning, bortsett från att nominativändelsen oftast utelämnas: förlagans Puríður blir Puríð och Pórður blir Pórð (Da/No: Tord) osv. Undantaget är s.k. ija-stammar där ändelsen kvarstår, exempelvis Pórir (Da/No: Tore). Även isländska ortnamn behandlas på samma sätt (t.ex. Borgarfjörður > Borgarfjörð). Såvitt bekant har detta system aldrig använts tidigare vid översättning till svenska av vare sig gammal eller modern isländska. ${ }^{10}$

Saken kompliceras dock av att vissa namn anpassas om de anses äga hävd på svenska (t.ex. Erik blodyx), vilket ibland leder till inkonsekvenser. Jarlen som Gunnlaug besöker i Skara heter Sigurd i $S v$ (men Sigurd i $D a /$ No) medan hans norske kollega försvenskas till Erik (No: Eirik). Den norskfödde grönlandskolonisatören skrivs däremot med diftong och accenttecken i $S v$ : "Eirík den röde". Vidare förekommer namnet Olof i fyra varianter: Olof Skötkonung heter så i GS men Olaf i Hallfreðs saga liksom i namnregistret. Olof Trätälja, som figurerar i bl.a. Egils saga, behåller däremot alltid sitt svenska namn. De norska namnarna heter Olav och islänningarna Ólaf i $S v$. (I $D a / N o$ förekommer enbart formen Olav.)

Enligt redaktörerna står troheten mot originalets namnformer"iöverensstämmelse med modern översättningspraxis" ( $S v$ : xii), ett argument som dock inte i sig bevisar det nya systemets överlägsenhet. Dessutom handlar det som sagt beträffande sagaöversättning snarast om ett brott mot praxis, vilket framgår av en jämförelse mellan svenska översättningar av Njáls saga (se tab. 1).

Lars Lönnrot följde alltså traditionen med anpassade namn i Njals saga från 2006, men när texten publicerades i Sv 2014 tillämpades dennas namnåtergivning.

Vad är avsikten bakom traditionsbrottet i $S v$ ? Möjligen är de islandiserade namnen tänkta att signalera autenticitet och därmed stärka nyöver-

${ }^{10}$ Däremot tycks $S v$ ha fått en efterföljare i översättningen av Bergsveinn Birgissons Den svarte vikingen (2019), med den anmärkningsvärda skillnaden att översättaren John Swedenmark låter kvinnonamnen behålla nominativändelsen, t.ex. Ragnhildur, Sigríður, Puríður osv. i motsats till Guðmund, Ingólf etc. Ett möjligt skäl till detta kan vara att formen Guðmund finns i det isländska paradigmet (i ackusativ) medan kvinnonamnen har ackusativformen Sigríði etc. 
Tab. 1. Några namn i översättningar av Njáls saga.

\begin{tabular}{lllll}
\hline Översättning & Ásgrímr & Hrútr & Mörðr & Práinn \\
\hline A.U. Bååth (1879) & Åsgrim & Rut & Mård & Tråen \\
Hjalmar Alving (1943) & Asgrim & Hrut & Mård & Traen \\
Åke Ohlmarks (1964) & Åsgrim & Hrut & Mård & Tråen \\
Ingegerd Fries (1981) & Asgrim & Hrut & Mård & Traen \\
Lars Lönnrot (2006) & Åsgrim & Hrut & Mård & Tråen \\
Lars Lönnrot (2014) & Ásgrím & Hrút & Mörð & Práin \\
\hline
\end{tabular}

sättningens auktoritet som trogen återgivning av originalet. Namnformerna understryker vidare att originaltexten är skriven just på isländska, inte på "gammal götiska". (Kanske spelar det in här att $S v$ har en islänning som huvudredaktör?) Uttalet försvåras hursomhelst, eftersom det onekligen blir besvärligare för svenskar att diskutera t.ex. Gunnar på Lidarände om han bor på Hlíðarendi. ${ }^{11}$ För att inte tala om Hallfreð vandræðaskáld. Ty även binamnen behåller ofta sin isländska form i $S v$, i motsats till $D a / N o$ och äldre svenska översättningar, vilket leder till en viss förlust i begriplighet; jfr t.ex. "Auðun Festargram" i $S v$ med "Ødun Lænkehund" i $D a$ eller "Audun bandhund" i Alvings och Ohlmarks' svenska översättningar.

\subsection{Historiskt presens}

Att ha enhetlig namnåtergivning i hela utgåvan ter sig rimligt, oavsett vilka principer som valts, men det tycks mindre tvingande att som $S v$ nästan helt avstå från historiskt presens (jfr Edlund 2017: 374f). Da däremot bevarar tempusbyte "i tillempet form" (LIII), vilket innebär att växling i allmänhet tillåts mellan grafiska meningar men inte inom dem. Historiskt presens undviks för övrigt även i den engelska utgåvan (Eng: xv), vilket kanske har påverkat den svenska. ${ }^{12}$ De svenska redaktörerna motiverar sitt beslut bl.a. med att förkortningar i handskrifterna kan göra det svårt att avläsa rätt verbform (t.ex. av anföringsverben meela och segja): ${ }^{13}$

\footnotetext{
${ }^{11}$ Namnformerna motverkar sålunda $S v$-redaktören Karl G. Johanssons förhoppning om "en svensk text som kan läsas högt" (citat i Edlund 2017: 374). Sv innehåller inte heller några uttalsanvisningar, vare sig för modernt eller fornisländskt uttal.

${ }^{12} \mathrm{Om}$ (frånvaron av) historiskt presens i engelska sagaöversättningar - och specifikt i GS - se Durrenberger \& Durrenberger 1992: 51-57.

${ }^{13}$ Lars Lönnroth (1996: 38) gör en poäng av en tempusväxling i Bolles vredesutbrott mot
} 
Tab. 2. Anföringsverb i GS.

\begin{tabular}{lllll}
\hline Presens/preteritum & $I s$ & $D a$ & No & Sv \\
\hline segir/sagði & $91 / 14$ & $25 / 112$ & $80 / 142$ & $7 / 130$ \\
svarar/svaraði & $66 / 2$ & $62 / 7$ & $65 / 2$ & $2 / 63$ \\
maelir/maelti & $0 / 68$ & - & - & - \\
\hline S:a presens/preteritum & $157 / 84$ & $87 / 119$ & $145 / 144$ & $9 / 193$ \\
\hline S:a & 241 & 206 & 289 & 202 \\
\hline
\end{tabular}

Bruket av historiskt presens i moderna utgåvor av isländska sagatexter bygger således ofta på osäker filologisk grund. På grund av detta har de föreliggande översättningarna mestadels avstått från att markera historiskt presens, men också för texthelhetens skull, då denna tidsform i översatt form lätt kan framstå som stilistiskt mer markerad och regelmässig än i källtexterna. $(S v \text { : XIII) })^{14}$

Men det finns mycket annat som står "på osäker filologisk grund" såsom bl.a. interpunktion och kapitel- och styckesindelning. T.ex. delas GS upp i hela 368 stycken i $I s$, vilket i stort sett följs i $\mathrm{Da} / \mathrm{Sv}$ medan $\mathrm{No}$ reducerar dem med mer än hälften (se tabell 3); detta att jämföra med exempelvis utgåvan i serien Íslenzk fornrit där GS indelas i 15 stycken.

I tabell 2 redovisas tempus vid tre anföringsverb, varav framgår hur presens ändrats till preteritum i $S v$.

Det är vidare värt att nämna att det typiska anföringsverbet vid dikter, kveða, används 28 gånger i GS i Is (enbart i preteritum, kvað) och 26 gånger i $\mathrm{Da}$ men inte alls i $S v$. Det förefaller dock osannolikt att verbet kvacde skulle "finnas" i högre grad på danska än kväda på svenska, utan frånvaron illustrerar snarare $S v$ :s vilja att distansera sig från en äldre svensk sagatradition.

Att $N o$ har betydligt fler fall av anföringsverb än $D a / S v$ beror på att de senare i stort sett helt strukit vad som kan kallas "pleonastisk anföring" (se tabell 3): ${ }^{15}$

Gudrun (Laxdalingarnas saga): "Att detta utbrott är något ovanligt och just därför särdeles omskakande markeras till yttermera visso av att berättaren växlar tempus till historiskt presens ('Då säger Bolle')". Lönnroths analys bygger på en tidigare översättning till svenska, men utifrån $S v$ fungerar inte exemplet - "Då sade Bolli" ( $S v$ V: 81) - vad det än sedan står i handskrifterna.

${ }^{14}$ Den sista meningen i citatet är svårtolkad då "markerad" närmast är en motsats till "regelmässig".

${ }^{15}$ All typografisk framhävning i citat är min om inte annat anges. 
Jarl mcelti: "Skúli Porsteinsson," segir hann, "hvað manna er pessi á Íslandi?" (Is: 1174)

Jarlen sa: "Skule Torsteinsson," sa han, "hva slags folk på Island kommer denne mannen fra?" (No: 273)

Jarlen sagde: "Skule Torstenssøn, hvad slags familie på Island stammer han fra?" (Da: 305)

Jarlen sade: "Skúli Porsteinsson, vad är det för människor på Island som han härstammar från?" (Sv: 280)

En skillnad mellan Is och No är emellertid att den förra alltid har två olika verb, vilka dessutom oftast står i olika tempus; den absolut vanligaste kombinationen är maelti i preteritum och segir i presens som i exemplet ovan. Intrycket av (onödig) upprepning blir sålunda starkare i No.

\subsection{Ordförråd}

Beträffande ordförrådet tycks alla redaktionerna vilja begränsa till ett nödvändigt minimum den norröna ordskatt som präglat äldre översättningar (No är dock minst restriktiv). ${ }^{16}$ T.ex. lyser fränder och fränkor helt med sin frånvaro i de tre GS medan släktingarna är desto talrikare. Målet tycks vara en text som varken ska framstå som modern eller gammaldags: "Det har i sagens natur ikke været en målsætning at lade sagaerne fremstå som moderne tekster. [...] Arkaiske ord og vendinger er så vidt muligt undveget" ( $D a$ : L; kursiv i orig.). Beträffande lånord vill dock $D a$ vara "sprogligt inkluderende" och tillåta främmande ord med visst burspråk i danska - exempelvis "økonomi" - medan senare lån undviks: "det går tilsyneladende en grænse her, som de fleste oversættere og læsere ikke $\emptyset$ nsker overskredet" (Da: LII). Engelska lånord är alltså inte okej.

Att policyn skiljer sig åt framgår av GS som på danska har fler latinbaserade lånord än $N o / S v$ :

blev meget aggressiv (Da: 298) svært sint (No: 267); brösta upp sig (Sv: 283)

Vi generer sagesløse folk (Da: 307) går løs på (No: 274); trampar på (Sv: 291)

\footnotetext{
${ }^{16}$ T.ex. översätter Alving ordet vanleikr med "vänhet" (på tal om Helga den fagra) men förklarar i en fotnot att det "närmast [torde] betyda vad vi kalla charm", ett ord som i detta sammanhang "förbjuder sig självt" (1938: 268).
} 
Gunløg takker ham for invitationen (Da: 313)

at han [...] ikke kendte til detaljerne (Da: 313)

Torkel [...] havde inviteret Illuge Sorte (Da: 316)

på græssletten stod folk i en cirkel

(Da: 321) tilbudet (No: 279); erbjudandet ( $S v$ : 297)

men bare uklart (No: 279); inte kände till allt $(S v: 297)$

innbød (No: 281); bjudit (Sv: 299)

ring (No: 286); ring ( $S v: 304)$

Detta modernare ordförråd förekommer även i dikterna i $D a$, möjligen som avsiktliga stilkrockar: "nu har jeg chancen/ til at vise hvorfor" (vers 4); "sprang på mig konstant/ i spyddenes spektakel" (vers 22).

Ett tvärt kast mellan register uppstår i Da/No när det norröna fylgjor står intill lånorden "gravid" respektive "personer":

De fugle må være stormænds fylgjer, og din kone er gravid [...] (299)

Disse fuglene kan være fylgjene til viktige personer. Kona di er med barn [...] (267)

Örnarna och falken måste vara stora mäns fylgjor. Din hustru väntar barn [...] (283)

Exemplet illustrerar också karakteristiskt hur det talspråkligare "er med barn" i No kontrasterar mot det mer neutrala "väntar barn" i $S v$.

\subsection{Ordantal och meningslängd}

Redaktörerna för de olika utgåvorna har beredvilligt gett tillgång till GS digitalt och sålunda har vissa parametrar kunnat undersökas maskinellt, vilket redovisas i tabell 3 .

Som tabell 3 visar har ordantalet ökat påfallande i $\mathrm{Da}$ och $N o$, med omkring 9\%, medan ökningen på knappt 3\% i Sv är förväntad vid källtextnära översättning från isländska (bl.a. därför att obestämd artikel tillkommer). Men $S v$ har å sin sida ökat antalet grafiska meningar avsevärt, vilka då blivit kortare i genomsnitt. Förkortningarna resulterar ibland i en effektfull komprimering, som i följande avsnitt vilket fördelaktigt tål jämförelse med expansionen i $\mathrm{Da} / \mathrm{No}$ :

"Hvar komu feður okkrir pess," segir hann, "að minn faðir væri eftirbátur píns föður, hvar nema alls hvergi? Skal og svo með okkur vera.” (1179; 24 ord) 
Tab. 3. Några variabler i GS (exklusive poesi och paratext).

\begin{tabular}{lllll}
\hline & Is & $D a$ & No & Sv \\
\hline Antal ord & 9598 & 10520 & 10469 & 9861 \\
Ökning \% & - & 9,5 & 9,0 & 2,7 \\
\hline Stycken & 368 & 354 & 127 & 359 \\
\hline Punkt & 590 & 634 & 631 & 713 \\
Kolon $^{\mathrm{a}}$ & 158 & 161 & 157 & 159 \\
Frågetecken & 34 & 34 & 34 & 37 \\
Utropstecken & 0 & $10(!)$ & 0 & 0 \\
\hline S:a grafiska meningar & 782 & 839 & 822 & 909 \\
Ord/grafisk mening & 12,3 & 12,5 & 12,7 & 10,8 \\
\hline Inskjuten (pleonastisk) anföring & 55 & 11 & 55 & 5 \\
\hline Totalt antal eg/jeg/jag & 93 & 112 & 115 & 121 \\
Varav initialt (Eg/Jeg/Jag) & 12 & 35 & 27 & 43 \\
\hline
\end{tabular}

$\underline{\text { Not }}$

a Kolon förekommer nästan uteslutande i anföringskonstruktioner av typen "Gunnlaug sade/svarade:".

"Hvornår er det nogensinde sket for vores fædre, at min far var på slæb hos din far? Det er aldrig nogensinde hændt, og sådan kommer det heller ikke til at blive mellem os." (311; 33 ord)

"Når har det vært slik med fedrene våre", sier han, "at min far diltet etter din far? Aldri har det vært slik, og slik skal det også være med oss.” (277; 30 ord)

"När hängde min far i släptåg efter din far? Aldrig. Detsamma skall gälla oss." (295; 14 ord)

Men strategin med fler och förkortade meningar kan även orsaka en viss monotoni i $S v$ när korta huvudsatser staplas på varandra:

Jafnan skemmtu pau Helga sér að Helga och Gunnlaug brukade roa sig tafli og Gunnlaugur. Lagði hvort med brädspel. De fattade snart tycke peirra góðan pokka til annars för varandra. Detta skulle visa sig bráđlega sem raunir bar á síðan. Pau senare. De var i samma ålder. (285) voru mjög jafnaldrar. (1170)

$S v$ har här fyra jämnlånga huvudsatser (5-8 ord) som alla inleds med 
subjektet, medan originalet har tre huvudsatser av varierande längd $(9,13$ och 4 ord) av vilka en inleds med ett tidsadverbial, en med tomt fundament (s.k. narrativ inversion) och bara den sista med subjektet. ${ }^{17}$ Korta meningar hör för övrigt till de stildrag Tage Danielsson överdriver i sin parodi på isländsk saga (Sigurds saga), som har en genomsnittlig meningslängd på cirka fem ord..$^{18}$ Sigurds saga excellerar även i den för sagastilen typiska topikaliseringen ("Harald dräpte jag. Pris rönte jag därför."), vilken $S v$ snarast underutnyttjar. En genomgång av de två första kapitlen i GS visar att 50\% av huvudsatserna inleds med annat än subjekt i $I s$, mot $30 \%$ i $N o$ och ungefär $25 \%$ i $D a / S v$.

I No tycks ordexpansionen inte minst syfta till att nå ett talspråkligare tonfall:

"Pitt fullting vildi eg hafa til kvonbænar við Porstein Egilsson að biðja Helgu dóttur hans." (1180; 15 ord)

"Jeg ville gjerne ha din hjelp til å dra på frierferd til Torstein Egilsson for å be om Helga, datteren hans." (278; 21 ord)

"Jag vill ha ditt stöd i ett frieri. Jag skall be Porstein Egilsson om hans dotter Helga." (295; 17 ord)

Citatet ovan illustrerar även hur $S v$ typiskt delat en grafisk mening i två vilka båda inleds med samma subjekt, jag (jfr tabell 3).

\subsection{Dikterna}

Den inflikade poesin med versmåttet dróttkvaett hör som bekant till det mest svåröversatta i sagorna, och det finns olika uppfattningar om vad i den som bör bevaras. Att bevara "allt" går inte. Samtliga redaktörer diskuterar problemet:

\footnotetext{
${ }^{17}$ Ett antal läsarreaktioner på GS (Sv) har samlats in, bl.a. följande från en gymnasielärare i svenska (64 år): "Stilen är typisk för isländska sagor, korta och okomplicerade meningar, nästan inga bisatser". Men $S v$ framstår alltså i detta avseende som "isländskare" än originalet: 10,8 ord per grafisk mening mot 12,3 i Is.

${ }^{18}$ Ur Sigurds saga (som blott är 1 sida lång): "En man hette Sigurd. Starkast var han på Island. [...] Harald hette en väldig kämpe. [...] I kämpalek möttes Harald och Sigurd. [...] Sigurd spräckte Haralds skalle. Ihjälslagen låg Harald, den väldige kämpen. [...] Ont tal nådde Sigurd. Sigurd trädde in över Gunnars tröskel. 'Ond tunga är mans bane', talade Sigurd. Sigurd dräpte Gunnar. Ting blev hållet. Sigurd talade: 'Harald dräpte jag. Pris rönte jag därför. Gunnar dräpte jag. Tvåfalt månde jag nu prisas.”" (Danielsson 1964: 89).
} 
[...] oversætterne [er] blevet opfordret til så vidt muligt at bevare kenninger, allitterationer og antallet af stavelser i de enkelte linjer. ( $D a$ : LI)

Vi har valgt å gjengi strofene slik at de blir lett forståelige for en norsk leser. [...] Av og til har vi gjengitt enkle kjenninger, men uten å gå særlig langt i å gjenskape skaldens poetiske språk. (No: XLI)

De här föreliggande översättningarna är således att betrakta som ett slags kompromisser, där de innehållsliga och i någon mån de rytmiska elementen givits företräde. ( $S v \mathrm{~V}: 420)$

Ingen säger sig avse att respektera originaldikternas inrim eller onaturliga ordföljd, vilken senare delvis är en följd av kraven på inrim och allitteration (även om den ökade komplexiteten också kan ha tillskrivits ett värde i sig). ${ }^{19}$

Målsättningen att dikterna ska vara "lett forståelige for en norsk leser" bekräftas av den norska GS, som har kvar färre kenningar än $D a / S v$. Möjligen riskerar dock poesin då att bli lite poänglös eftersom själva sakinnehållet ofta är ganska trivialt. Men No har å andra sidan flest regelrätta allitterationer: av totalt 81 radpar i dróttkvaett är 17 i stort sett korrekt allittererade i $N o$, mot fem var i $D a$ och $S v$, och endast $N o$ har strofer med komplett allitteration (vers 1 och 9). No har dessutom bevarat fler av de i originalet obligatoriska trokéerna i radslut: 149 av 162 (mot 117 i $D a$ och 135 i $S v$ ).

No utelämnar sålunda oftast kenningarna medan de i $D a$ förklaras i en parallell spalt och $S v$ ibland bakar in begriplighet genom explicitering tillsammans med bevarad kenning. I strof 12 exemplifieras de tre strategierna:
[...] så $\phi$ lskibets Njфrun
Du kan ikke lege
Du, ölkarets Njörun,
ej kunne forbinde sårene fra sverdet. bistod mig inte, [ølskibs $>$ drikkehorns $>$ Njørun (281) (299)
(gudinde) $>$ kvinde] (315)

I Sv står vidare originalet originellt nog i direkt anslutning till diktöversättningarna. Syftet är naturligtvis inte att underlätta förståelsen av dikterna, utan troligen återigen att påminna läsarna om att de faktiskt läser en översättning. Kanske fyller originaldikterna också en dekorativ funktion?

\footnotetext{
19 Åke Ohlmarks är förmodligen ensam om att konsekvent ha såväl inrim som regelrätt allitteration i sina diktöversättningar (ofta dock på bekostnad av trokéerna i radslut). Han går även längst i fantasifulla kenningar varför dikterna ibland blir tämligen obegripliga även för högt kompetenta läsare.
} 
Intrycket att $S v$ är något formellare, och möjligen försiktigare, än $D a / N o$ gäller även dikterna. T.ex. i vers 14 där Gunnlaug förbannar Helgas föräldrar för att de åstadkommit den vackra flicka som vållar honom smärta:

Lad trollen tage bondens Djevelen dem hente! mesterværk!
Jeg dem begge unner også alt det verste. (282)
Må de illa lönas för att ha avlat den blida och dömas hårt för dådet. (300)

(Anslaget i $D a$ påminner för övrigt om Ohlmarks' småfräcka version (1963): "Trollen tage den dagens/ trägna drängverk i sängen.")

En intressant skillnad mellan $S v$ å ena sidan och $D a / N o$ å den andra visar sig i strof 20 i GS som är identisk med strof 3 i Kormáks saga. ${ }^{20}$ De två sagorna har olika översättare i alla tre redaktionerna och i både $D a$ och No skiljer sig versionerna åt, här exemplifierat med den senare: ${ }^{21}$

Linpyntet var kvinnen

da hun kom imot meg, et blikk hun mot meg kastet, kvast som haukens var det. (GS; No: 285)
Så bjart den blinket, månen, i brynene hennes, under skinnende lyse panna, så satt hun haukeblikk i meg. (Kormaks saga; No: 144)

I $S v$ däremot är versen identisk i båda sagorna, vilket tyder på en hårdare redaktionell styrning av dikterna.

\section{Sammanfattande diskussion}

I Norge kom GS ut år 1859 som bilaga till tidskriften Folkevennen ("Oversat fra Gammelnorsk af O. Rygh"), och 1872 kom P. A. Gödeckes svenska översättning i skriftserien "Läsning för folket", utgiven av "Sällskapet för nyttiga kunskapers spridande". Uppenbart har GS m.fl. isländska sagor då ansetts som lämplig läsning för folkets breda lager. Vilket osökt ger anledning att återvända till rubrikens frågor rörande de skandinaviska nyöver-

\footnotetext{
${ }^{20}$ Enligt Nordal (1938: XLIII) är Kormákr tvivelsutan diktens upphovsman ("má telja vafalaust, að hún sé eftir Kormák"), men vad detta antagande bygger på framgår inte.

${ }^{21}$ Originalet lyder: "Brámáni skein brúna / brims af ljósum himni / Hristar hörvi glæstrar / haukfránn á mig lauka" (Is II: 1188).
} 
sättningarna: "Hur? För vem? Varför?”. Som flera forskare betonat (t.ex. Reiß \& Vermeer 1991: 96f) är översättning en målstyrd verksamhet, och ett svar på frågan "Hur?” kan antyda för vem en översättning är avsedd. Därför ska här några karakteristiska drag hos de tre utgåvorna/översättningarna rekapituleras, samt - måhända en smula spekulativt - en tänkt målgrupp föreslås.

$D a$ utmärks av omfattande paratexter och är dessutom ensam om att i brödtexten grafiskt markera (med ${ }^{\circ}$ ) de begrepp som tas upp i ordförklaringarna, t.ex. i GS: "væggene i hans obod var styrtet sammen" (298). De rikliga förklararingar i parallellspalt vid dikterna förstärker intrycket av pedagogisk ambition. Vidare verkar den danska GS ta ut svängarna mer än $N o$ och i synnerhet $S v$, vilket visar sig t.ex. i tillagda utropstecken ("Som talt af den braveste mand!"; 320), viss talspråklighet ("Kongen svarer: Det var skidt."; 307), en liberal låneordspolicy som ibland medför stilkrockar, och dessutom i enstaka arkaismer: "Hvad forestiller I Jer, Herre?" (309).22 Den tydliga pedagogiska ambitionen för tankarna till den danska folkhögskolerörelsen, för vilken de isländska sagorna som bekant haft en mycket stor betydelse. Och kanske vänder sig $D a$ framförallt till det uppväxande släktet?

No har något mindre av förklarande paratexter än $D a / S v$, och dikterna är lättillgängligare. Tonfallet i GS är ofta talspråkligt med många partikelverb ("De kom raskt godt ut av det med hverandre"; 277) och vissa feminina a-former: bua, jula, elva, sola etc. (men däremot t.ex.tiden, saken, hånden, natten); possessiva pronomen är oftast efterställda (kona di, datteren din). Vidare förekommer något fler "norrönismer" i No än i Da/Sv: austmann (Sv: norrman), grid, svienes (Da: svenskerne; $S v$ : svenskarnas). Det är en vanlig uppfattning att de isländska fornsagorna, i högre grad än i Danmark och Sverige, fortfarande utgör en integrerad del av det norska kulturarvet och detta skulle kunna förklara den populärare ansatsen. För folket?

$S v$ tycks generellt ha förenhetligats mer redaktionellt än $\mathrm{Da} / \mathrm{No}$, t.ex. i tempusbruket och i dikterna. I GS uppvisar $S v$ en stramare och ordknappare stil än de andra två, och genomgående bruk av bl.a. sade och skall bidrar till en viss formalitet. Ordförrådet är neutralt - såväl latinska som norröna lånord undviks - och meningslängden har förkortats med viss syntaktisk monotoni som följd. Och möjligen är de förkortade

\footnotetext{
${ }^{22}$ Pluralformerna I och Jer (med versal) är översättning av pér/yður som Gunnlaug använder vid tilltal av en kung eller jarl, vilka i sin tur duar honom. No har De/Dem, medan $S v$ en gång översätter med ni/er (290) och sedan alltid du/dig.
} 
meningarna det stilmedel som återstår för att signalera "isländsk saga" efter att $S v$ avhänt sig en äldre traditions arkaismer, tempusbruk och frekventa topikaliseringar? Originalspråkets synlighet i namnformerna och i dikterna tyder eventuellt på en "lärd" målgrupp: För den bildade borgerligheten? (Om någon sådan fortfarande finns?)

Slutligen till frågan "Varför?". Det är en ofta upprepad förhoppning att nyöversättningar ska göra klassiska verk "tillgängliga för nya läsare" och då särskilt för "nya generationer" (jfr Ringmar 2012 ${ }^{23}$ ), en tankefigur som återfinns i de tre regenternas hälsningsord:

Det er mit håb, at sagaerne i denne nye oversættelse vil nå ud til så mange som muligt, så nye generationer kan få samme glæde af sagaerne, som jeg har haft. (Margrethe II)

Ved at islendingesagaene nå foreligger samlet $\mathrm{i}$ en ny norsk oversettelse, kan flere - og nye generasjoner - få glede av dette verdifulle verket. (Harald V)

Det är därför glädjande att den [sagalitteraturen] på nytt görs tillgänglig för oss, och då i ny språklig dräkt. (Carl XVI Gustaf)

Men i detta sammanhang förefaller argumentet svagt. De mer kända sagorna, vilka säkert även fortsättningsvis förblir de mest lästa, är lättillgängliga i äldre översättningar på bibliotek, antikvariskt eller online. Att just den senaste översättningen öppnar texterna för nya generationer är i och för sig tänkbart, men i revideringar av de äldre har många eventuella läshinder undanröjts, och dessutom finns det säkert läsare - även yngre - som efterfrågar den fornnordiska atmosfär som norröna lånord tillsammans med konjunktiv- och pluralformer av verben kan tänkas skänka.

I det inledande citatet från Islandsbloggen kritiseras Saga forlag för att $S v$ inte tillräckligt har kunnat nå "svenska lärare". Den freudianska felskrivningen (?) "lärare" är talande, ty ännu för 50-60 år sedan hade t.ex. gymnasielärare i svenska varit en självklar målgrupp för en utgåva av detta slag. Bland deras nutida kolleger är det förmodligen mycket få som ens känner till $S v$ :s existens. Det är alltså lite som tyder på att Edlunds

\footnotetext{
${ }^{23}$ Det framhålls inte sällan att en nyöversättning nu "äntligen" ger oss tillgång till ett visst verk, som t.ex. i en recension av Kormaks saga (2008): "Kormaks saga har tidigare översatts till svenska av A. U. Bååth [...] och Åke Ohlmarks [...]. Båda översättningarna är föråldrade och är snarast att betrakta som romantiserade tolkningar av originalet. Genom [Ingegerd] Fries professionella och moderna översättning blir Kormaks saga här för första gången tillgänglig för en svensk publik" (Haugen 2011: 106-107). Men vad ska man då säga om Kristjan Hallbergs översättning i $S v$ (2014)? Att den "för andra gången" gör Kormaks saga tillgänglig för en svensk publik?
} 
förhoppning om "en stor läsekrets" (2017: 375) för $S v$ skulle ha infriats, även om en framtida nätpublicering kan ändra på den saken.

Att initiativet till nyöversättningsprojekten, liksom en stor del av finansieringen, kommit från Island är talande. Här sågs fornsagorna länge som en nationell skatt och nästintill heliga skrifter. Berömd - eller snarare beryktad - är den lag från 1941, senare förklarad grundlagsstridig, som gav staten äganderätten till all isländsk litteratur från före 1400, och enligt vilken Halldór Laxness m.fl. dömdes för att ha vanhelgat sagorna med sina modernortografiska och "ovärdiga" utgåvor (Helgason 1998: 13368, 2002; jfr Ringmar 2011).

Så rimligtvis förblir det ur ett isländskt perspektiv viktigt att även nyutgåvor som de skandinaviska får en fysisk utformning som återspeglar islänningasagornas ställning som "de nordiska folkens enda garanterat slitstarka bidrag till den så kallade världslitteraturen" (Henrikson 1981: 15). Inledningsorden med autograf från de tre regenterna i färggrann ornat bidrar till en air av pompa och ståt. Och att de skandinaviska nyöversättningsprojekten samordnats multiplicerar förstås deras genomslag med tre. Det förvånar således inte heller att evenemang kring dem använts för att förgylla Islands ordförandeskap i Nordiska ministerrådet, dels vid ovannämnda konferens i september 2019, dels - och framförallt - i juni 2014 när de tre boxarna släpptes under festliga former i kongresscentret Harpa i Reykjavik. I dubbel bemärkelse tungt vägande litteratur.

\section{Referenser}

\section{Primärmaterial}

$D a=$ Islændingesagaerne I-V. Samtlige sagaer og niogfyrre totter. Utg. av A.

Lassen. 2014. Reykjavík: Saga forlag.

Eng = The complete sagas of Icelanders I-V. Including 49 tales. Utg. av V. Hreinsson \& R. Cook. 1997. Reykjavík: Leifur Eiríksson Publishing,

Is = Íslendinga sögur og pættir I-III. Utg. av B. Halldórsson \& al. 1987. Reykjavík:

Svart á hvítu.

No = Islendingesagaene I-V. Samtlige sagaer og førtini tætter. Utg. av J. G.

Jørgensen \& J. R. Hagland. 2014. Reykjavík: Saga forlag.

$S v$ = Islänningasagorna I-V. Samtliga släktsagor och fyrtionio tåtar. Utg. av K.

Jóhannesson, G. D. Hansson \& K. G. Johansson. 2014. Reykjavík: Saga forlag. 


\section{Övriga referenser}

Alvin, Hjalmar, 1938: Förord. I: Egil Skallagrimssons saga och Gunnlaug Ormstungas saga. Isländska sagor, band 3. Stockholm: Bonniers.

Bengtsson, Nils Otto, 1988: Preben Nodermann - legend i Lund. (Gamla Lund: Årsskrift 70.)

Birgisson, Bergsveinn, 2019: Den svarte vikingen. Översättning John Swedenmark. Stockholm: Bazar,

Bååth, A. U., 1910: Sagan om Gunnlög Ormtunga och andra sagor. 2., genomsedda uppl. Stockholm.

Danielsson, Tage, 1964: Sagor för barn över 18 år. Stockholm: Wahlström \& Widstrand.

De isländska sagorna, 1963: Översättning Åke Ohlmarks. Band 2: Västlandssagor. Stockholm: Steinviks.

De isländska sagorna, 1964: Översättning Åke Ohlmarks. Band 5: Sagorna från Öst- och Sydisland. Stockholm: Steinviks.

Durrenberger, E. Paul \& Dorothy Durrenberger, 1992: The Saga of Gunnlaugur Snake's Tongue. With an Essay on the Structure and Translation of the Saga. Rutherford etc.: Associated University Press.

Edlund, Lars-Erik, 2015: Islänningasagorna i nyöversättning - ett nordiskt storverk. I: Nordisk tidskrift (häfte 4). S. 457-470.

Edlund, Lars-Erik, 2017: Recension av Islänningasagorna I-V. Samtliga släktsagor och fyrtionio tåtar. I: Scripta Islandica (vol. 68). S. 369-375.

Hannesdóttir, Anna Helga, 1998: Skimmer, chimärer och chimairor. I: Form innehåll - effekt. Stilistiska och retoriska studier tillägnade Peter Cassirer på 65-årsdagen. Utg. av A. Lundqvist \& al. Göteborg: Institutionen för svenska språket, Göteborgs universitet. S. 67-78.

Haugen, Susanne, 2011: Recension av Kormaks saga. Scripta Islandica. S. 105107.

Helgason, Jón Karl, 1998: Hetjan og höfundurinn. Brotúríslenskri menningarsögu. Reykjavík: Heimskringla.

Helgason, Jón Karl, 2002: Alpingi, fornritin og tuttugasta öldin. I: Handritin. Ritgerðir um íslensk miðaldahandrit, sögu peirra og áhrif. Utg. av Gísli Sigurðsson \& Vésteinn Ólason. Reykjavík: Stofnun Árna Magnússonar. S 145-155.

Henriksson, Alf, 1981: Isländsk historia. Stockholm: Bonniers.

Isländska sagor, 1943: Översatta från fornisländskan och utgivna av Hjalmar Alving. Band 4: Njals saga. Stockholm: Bonniers.

Lassen, Annette, 2014: N. M. Petersens sagaoversættelser. I: Filologen N. M. Petersen - grundlægger og fornyer. Utg. av Frans Gregersen \& al. København: Selskab for Nordisk Filologi. S. 57-80.

Lönnroth, Lars, 1996: Skaldemjödet i berget. Essayer om fornisländsk ordkonst och dess återanvändning i nutiden. Stockholm: Atlantis.

Nials saga, 1879: Från fornisländskan af A. U. Bååth. Stockholm: Seligmann. 
Njals saga, 1981: Översättning Ingegerd Fries. Höganäs: Läsabra.

Njals saga, 2006: Översättning och inledning av Lars Lönnroth. Stockholm: Atlantis.

Nordal, Sigurður, 1938: Formáli. I: Borgfirðinga sǫgur. Íslenzk fornrit III. Reykjavík: Hið íslenzka fornritafélag.

Reiß, Katharina \& Hans J. Vermeer, 1991: Grundlegung einer allgemeinen Translationstheorie. 2. Auflage. Tübingen: Niemeyer.

Ringmar, Martin, 2011: Tecken som gör skillnad! Interpunktion och grafisk struktur i de nordiska översättningarna av Salka Valka. I: Transformationer. Valda texter från IASS 28:e konferens i Lund 2010. Utg. av P. E. Ljung. Köpenhamn/Lund: Centre for Scandinavian Studies. S. 337-347.

Ringmar, Martin, 2012: ”... anses vara mycket god.” Hur åsikter om (ny)översättningar uppstår och sprids: Exemplet Laxness. I: Aspekter av litterär nyöversättning - Aspects de la retraduction littéraire. Utg. av O. Eriksson. Växjö: Linnaeus University Press. S. 165-181.

Small, L. M, 1935: Preface. I: Gunnlaugssaga ormstungu. Leeds School of English Language. (Texts and monographs: Number 1.)

\section{Summary}

In 2014 were published translations of the complete Íslendingasögur into Danish $(\mathrm{Da})$, Norwegian $(\mathrm{No})$, and Swedish $(\mathrm{Sw})$, each in five volumes with comprehensive paratexts. Involving some 60 translators and editors, this is presumably one of the biggest retranslation projects ever in Scandinavia and it has received substantial financial support in each country, respectively, as well as from Iceland. The initiative emanated with an Icelandic publisher, whose 1987 Icelandic edition of the sagas - with modernized spelling - served as a source text (Ice). However, having an Iceland-based publisher may have hampered the access to mainland Scandinavian markets and especially in Sweden sales have reportedly been poor.

Like all translations of sagas, the triplet had to face classical problems like the rendering of proper names, the narrative shifts between past and present tense, and the interspersed Scaldic poetry. As for names, $S w$ abandons the time-honoured tradition of adaptation and maintains their original forms including diacritics, save that the nominative ending -ur is omitted, e.g. Pórður > Pórð (Da/No: Tord). Sw also treads an original path in poetry translation by printing the original Icelandic stanzas in a parallel column. No, in contrast, opts for comprehensibility and simplifies most of the poetic kenningar, whereas $D a$ preserves them accompanied by extensive explanations. Concerning Norse loanwords - once the hallmark of saga translation - all three editions use them restrictively, and $D a$ even admits more Latin-based loanwords than has been customary in this genre.

As for the three versions of Gunnlaugs saga ormstungu (GS), $D a$ and $N o$ tend 
to verbosity with app. $9 \%$ more words than Ice (in contrast to $+3 \%$ in $\mathrm{Sw}$ ), and especially in No this serves to enhance a certain colloquial tone. $S w$, on the other hand, shortens and simplifies sentences by favouring main clauses with subject first, thus at times running the risk of syntactic monotony. It is furthermore suggested here, tentatively, that the differences in the three GS can be explained by different aims (and target groups?): A popular approach in No, a pedagogical zeal in $D a$, and a learned leaning in $S w$.

Keywords: Gunnlaugs saga, sagaöversättning, nyöversättningar

Martin Ringmar

Lunds universitet

Språk-och litteraturcentrum/Nordiska språk

Box 201, SE-22101 Lund, Sverige

Martin.Ringmar@nordlund.lu.se 


\title{
Kan fornisländskans rúnar betyda 'bokstäver'?
}

\author{
MiKAEL MALES
}

Det närmast förbehållslösa svaret på frågan i titeln har hittills varit 'ja' . Det mest välkända exemplet på denna betydelse återfinns i den Första grammatiska avhandlingen (ca 1150), där författaren argumenterar för att anpassa och utöka det latinska alfabetet för att uppnå ett mer grafofonematiskt precist skriftsystem som lämpar sig för fornisländskan. Han säger då till sin tänkta motpart att eigi er pat rúnanna kostr pó at pú lesir vel eða ráðir vel at líkindum par sem rúnarnar vísa óskýrt, heldr er pat pinn kostr (Hreinn Benediktsson 1972: 214). ${ }^{1}$ Enligt hittills existerande översättningar skulle detta betyda: 'det är inte bokstävernas förtjänst, utan snarare din egen, om du läser dem väl eller tolkar dem väl utifrån vad som är sannolikt i fall där bokstäverna ger oklart besked' .

Om översättningen är riktig är detta den enda gång avhandlingens författare använder rúnar för att beteckna latinska bokstäver. I det andra fall där han använder ordet betyder det sannolikt 'runor' (rúnar [heita] málstafir '[en typ av] bokstäver [heter] runor') (Hreinn Benediktsson 1972: 222). För bokstäver använder han annars alltid stafir, málstafir eller bókstafir, och då det rör sig om en terminologiskt medveten författare som skriver en avhandling om ortografi vore det uppseendeväckande om han plötsligt bytte beteckning.

\footnotetext{
${ }^{1}$ Citat återges med normaliserad ortografi.

${ }^{2}$ Den ende äldre forskare jag har funnit som uppenbarligen förstår rúnar här som 'runor' är Björn M. Ólsen, även om han inte ger en översättning av texten (Björn M. Ólsen 1883: 91-92). Också redaktörerna av Ordbog over det norrøne prosasprog tycks förstå passagen så (se nedan).
}

Males, Mikael. 2021. Kan fornisländskans rúnar betyda 'bokstäver'?

Scripta Islandica 72: 127-136.

(C) Mikael Males (CC BY)

DOI: $10.33063 /$ diva-439404 
Om avhandlingens författare istället åsyftar runor skulle detta inte bara vara i enlighet med den stringens för vilken han har blivit så beundrad i modern forskning. Hans kritiska hållning skulle dessutom bli mer begriplig, och detta får sägas vara giltigt även om han måhända syftar på det medeltida, mer exakta runinventariet som var under utveckling vid denna tid, eftersom ristare ytterst sällan konsekvent utnyttjade dess fulla potential, och då vokallängd inte markerades (något som åtminstone författaren menade att latinsk skrift tillät) (om grafofonematisk korrespondens under denna tid, se exempelvis Spurkland 2000: 163-65). För en grammatiker med medvetenhet om ortografi och olika skriftsystem (han anför på korrekt vis grekiska i sin argumentation) torde runorna ha tett sig som mycket inexakta och kunnat fungera som ett utmärkt exempel för att få motparten att inse behovet av ett mer otvetydigt skriftsystem.

Den förste grammatikerns konsekventa bruk av terminologi och runinventariets karaktär stödjer alltså att rúnar i den Första grammatiska avhandlingen genomgående skall översättas med 'runor'. Detta medför inte bara en nyöversättning, utan ger oss också ett nytt och samtida vittnesmål till hur runorna uppfattades som skriftsystem; deras inexakta karaktär kunde utan vidare förutsättas vara känd av den tänkte antagonisten i avhandlingen. En äldre uppfattning om att runskrift för praktiskt bruk var så gott som okänd på Island före ca 1200 har redan blivit ifrågasatt, och referensen i den Första grammatiska avhandlingen understryker att denna åsikt bör revideras. ${ }^{3}$

\section{Möjliga belägg på betydelsen 'bokstäver'}

Finns det då överhuvud taget belägg för betydelsen '(latinska) bokstäver'? De tre exempel som finns i Ordbog over det norrøne prosasprogs databas där en sådan betydelse kunde komma på fråga gäller skriftsystem andra än det latinska - såsom grekiska - eller inskriptioner på sten. ${ }^{4}$ Endast $\mathrm{i}$

\footnotetext{
${ }^{3}$ Se Hagland (1989) och Pórgunnur Snædal (2011).

${ }^{4}$ Så i Stefáns saga (inskription på gravsten; det syriska språket har just nämts och tecknen kräver tolkning av en biskop (en síðan réð Jóan episcopus rúnar). Det tycks alltså röra sig om främmande skrift ur protagonisternas perspektiv) (de Leeuw van Weenen 1993: 95); Klements saga (inskription på gravsten) (Larsson 1885: 73); Rómverja saga (ekki nam ek girðskar rúnar 'jag lärde mig inte grekisk skrift') (Meissner 1910: 52) (https://onp.ku.dk/ onp/onp.php?o65646, granskad 21 november 2020).
} 
dessa fall måste betydelsen vara en annan än 'runor' i modern bemärkelse, och ordet synes då betyda antingen 'monumentalskrift för inskription (på sten)' eller 'främmande skrift'. Som beteckning för skrift tycks rúnar alltså ha kunnat ha en något vidare betydelse än 'runor', men betydelsen var då snarast 'andra skriftsystem/skrifttyper', nämligen det som inte var vanlig, latinsk bokskrift. Det bör nämnas att jag först genomförde denna undersökning innan Ordbog over det norrøne prosasprogs databas hade försetts med översättningar. Sedan dess har redaktörerna placerat såväl passagen från den Första grammatiska avhandlingen som de exempel som nämnts ovan under betydelsen "rune, skrifttegn, bogstav (andet end latinsk)", helt i enlighet med mina observationer. Den betydelse som översättarna av den Första grammatiska avhandlingen har valt synes sålunda vara just den betydelse som ordet var markerat för att inte ha. ${ }^{5}$

I prosatext finns inget som motsäger denna semantik. Två poetiska passager kräver dock en närmare dryftning. I Hugsvinnsmál, en 1200-talsöversättning av lärodikten Disticha Catonis, lyder första halvan av strof 12: Bakk ok rúnir / kenn pú blíðliga / ger pú við góða vel (Clunies Ross et al. 2007-, 7: 367-68) 'lär vänligt ut / böcker och runor / och gör väl mot de goda'. Här synes skolning i grammatica åsyftas, och detta samt kopplingen till böcker gör att det ligger nära till hands att här tolka rúnir (en yngre form av rúnar) som 'latinsk skrift' . ${ }^{6}$ Den omfattande diskussionen av runor $\mathrm{i}$ den Tredje grammatiska avhandlingen - i en översättning av Priscianus Institutiones - visar dock att ingen motsättning behövde föreligga mellan studiet av runor och grammatica. Ett positivt indicium för att det faktiskt är runor som avses i Hugsvinnsmál finns i en liknande formulering i Rognvaldr jarls lausavísa 1: týnik trauðla rúnum / tíð’s mér bók ok smíðir (Clunies Ross et al. 2007-, 2: 576-77) 'jag glömmer knappast runor / jag är välbekant med böcker och hantverk'. Rognvaldrs prestation

\footnotetext{
${ }^{5}$ En ytterligare logisk möjlighet är att avhandlingens författare använder rúnar som ett överordnat begrepp 'skrifttecken' mot stafir 'skrifttecken specifika för ett språk'. Att så inte är fallet visas dock av avhandlingens början: en af pví at tungurnar eru [ó]líkar hver annarri [...] pá parf ólíka stafi í at hafa [...] (Hreinn Benediktsson 1972: 206) 'men eftersom språken är olika varandra [...] är det nödvändingt att ha olika skrifttecken i dem [...]' Stafr är alltså det överordnade begreppet, och det kan specificeras för de enskilda språken: [...] sem eigi ríta Grikkir látínustofum girzkuna ok eigi látínumenn girzkum stofum látínu [...] (Hreinn Benediktsson 1972: 206) '[...] liksom greker inte skriver grekiska med latinska bokstäver, eller latinarna latin med grekiska bokstäver [...]'. Däremot kan det överordnade stafr i norrönt också användas också om runor (se Hreinn Benediktsson 1972: 52-53).

${ }^{6}$ Så tolkas ordet av Finnur Jónsson 1931: 473. Den nya utgåvan översätter dock med 'runes' (Clunies Ross et al. 2007-, 7: 367).
} 
ligger alltså i att han behärskar både runor och latinsk skrift, och utifrån denna parallell är det rimligt att anta att detsamma åsyftas i Hugsvinnsmál. Däremot är den täta associationen mellan runor och latinsk skrift i sig av intresse. Detta styrker det intryck av bruket av runor som kan beläggas särskilt i norska inskrifter från ca 1200 och framåt; ristarna var ofta även boklärda och hade åtminstone grundläggande kunskaper i latin. ${ }^{7}$

Ett ord som aldrig har tolkats som 'bokstäver', men som likväl kunde föranleda en sådan tolkning, finns i Sigrdrífumál 19 (endast belagd i handskriften GKS 2367 4to, ca 1270). Strofen börjar: Pat eru bókrúnar / pat eru bjargrúnar [...] 'Det är bokrunor / det är räddningsrunor [...]'. Det synes sökt att tolka bókrúnar som något annat än skrifttecken i en bok, oavsett om det gäller runor eller latinsk skrift (runor ristade på bokträ har föreslagits; Finnur Jónsson 1931: 58). Som Aslak Liestøl för länge sedan konstaterade är det dock uppenbart att det här rör sig om ett skrivarfel; skrivaren har skrivit 'bocrunar' för 'botrunar'. Denna iakttagelse stöds av två runinskrifter. En runkavle från Bergen (N B257) har en besvärjelse som börjar: rist $\widehat{\text { ek }}$ : bot:runar : rist : $\widehat{\text { ek }}$ biabh : runar, i normaliserad form (med rättning av felristningen $\mathbf{b}$ för $\mathbf{r}$ ): ríst ek bótrúnar / ríst ek bjargrúnar 'jag ristar botrunor / jag ristar räddningsrunor' (Liestøl 1964: 41-46). Efter Liestøls tid har en besläktad svensk inskrift tillkommit. Kopparblecket ÖgNOR2001;32 Skänninge, kv. Abedissan (1000-1100tal) har texten luf-unarị... $\| . . . k$ butrunar, och oavsett hur den saknade texten skall rekonstrueras torde det vara okontroversiellt att här läsa orden lyfrúnar 'läkerunor' och bótrúnar 'botrunor' (Källström 2007: 356).

$c$ är det tecken man normalt skulle förvänta för $/ \mathrm{k} / \mathrm{vid}$ denna tid. Det lilla $t$ var å andra sidan intill förväxling likt $c$ (se illustration i Liestøl 1964: 46). Med stöd i runinskrifterna är det därför möjligt att fastslå att ordet bókrúnar är resultatet av en felläsning, snarare än en muntlig variant - det var de två tecknen, inte de två ljuden, som var lätta att blanda samman. Ordet måste rimligtvis ha betytt något även för skrivaren, men vid en tid och på en plats där runor nyligen hade behandlats utförligt i bokform (i den Tredje grammatiska avhandlingen, ca 1250) finns det inget skäl att anta att skrivaren förstod något annat än 'runor i böcker'. Han hade inget skäl att omdefiniera eller ifrågasätta runbegreppet som sådant.

\footnotetext{
${ }^{7}$ Se exempelvis Spurkland (2000: 193-96). Kanske blir kopplingen mellan inhemsk och latinsk lärdom ingenstans tydligare än på pinnen N B145, där en strof i dróttkvatt, och dessutom diktad med bara aðalhendingar, efterföljs av citatet omnia vincit amor, et nos cedamus amori 'kärleken övervinner allt, låt även oss ge efter för kärleken' från Vergilius tionde eklog.
} 
Med dessa två exempel ur poesin faller de sista indicierna på den neutrala betydelsen 'bokstäver'. Denna betydelse tycks heller inte vara belagd i fornsvenskan, eller i de två andra forngermanska språk där ordet används om någon form av skrifttecken. ${ }^{8}$ I den största fornengelska ordboken, Bosworth-Toller (1898), anges först båda betydelserna - 'a rune, a letter' - men det ges inga översättningar till de enskilda exemplen. De referenser som anförs översätts bäst med 'runor', utom i de fall som troligen felaktigt placerats under denna rubrik, men som snarare borde förstås som 'råd' . Bosworth-Toller hänvisar till Graffs massiva Althochdeutscher Sprachschatz där, som ofta i äldre ordböcker, ordets olika grundbetydelser anges på latin, och läsaren får veta att fornhögtyskans rúna kan betyda litera, alltså 'bokstav'. ${ }^{10}$ Alla Graffs exempel, i likhet med Bosworth-Tollers, stödjer dock en betydelse 'runa', eller möjligen, som i norrönt 'den andra (hemlighetsfulla/magiska/avvikande) skriften'.

\section{Den neutrala betydelsens bakgrund}

Graffs Althochdeutscher Sprachschatz kan troligen ge en fingervisning om hur den neutrala betydelsen 'bokstav' har hamnat i ordböcker över forngermanska språk. Latinet har aldrig haft ett eget ord för 'runor', något som tydligt visas av att när Venantius Fortunatus (500-tal) på latin ville uttrycka den specifika betydelsen 'runa' var han tvungen att låna in detta ord. ${ }^{11}$ Ett gångbart latinskt ord blev det dock aldrig, och i äldre ordböcker och översättningar var den naturliga översättningen därför littera. Allteftersom folkspråklig filologi åter blev en folkspråklig verksamhet återfördes de gamla översättningarna och definitionerna från latinet till språk som fortfarande, liksom under medeltiden, hade en distinktion mellan 'bokstäver' och 'runor'. De anförda textställena gjorde det uppenbart att betydelsen 'runor' var central, och ordboksförfattarna angav därför denna, men betydelsen av littera förblir likväl 'bokstav', och denna översättning

\footnotetext{
${ }^{8}$ Se Söderwall (1884-1918, 2: 269) och Söderwall, Supplement (1953-73, 2: 657).

${ }^{9}$ Så Layamons Brut, Ormulum och The Ancren Riwle (Bosworth \& Toller 1898: 804)

${ }^{10}$ Graff (1834-42, 2: 523-25). Schade (1882, 2: 729) definierar rúna - i betydelsen 'skrifttecken' - bara som altgermanischer Buchstabe, i enlighet med argumentet i denna artikel. Den stora Althochdeutsches Wörterbuch, utg. Grosse (1952-), har ännu inte kommit till $r$. ${ }^{11}$ Carm. vii. 18, 19: barbara fraxineis pingatur runa tabellis 'må de barbariska runorna bli målade på tavlor av askträ'.
} 
följde därför med in i ordböcker över medeltida folkspråk. I BosworthTollers fall kan den möjligen vara direkt avhängig av Graff. I fråga om den Första grammatiska avhandlingen har den arnamagnæanska utgåvan varit tongivande, och där översätts rúnar med litterae och characteres (Jón Sigurðsson et al. 1848-80, 2: 17, 23).

\section{Den förste grammatikern och isländska hållningar till runor}

Den neutrala betydelsen 'bokstav' har alltså lite med medeltiden och mycket med modern forskningshistoria och latinsk semantik att göra. Denna rättelse ger en säkrare läsning av ett antal textställen och är relevant för flera fornspråk. Etableringen av en riktig läsning av passagen i den Första grammatiska avhandlingen gör det också möjligt att följa en utveckling $\mathrm{i}$ attityden till runor hos tre isländska författare (en mer fullständig redogörelse för denna utveckling återfinns i Males 2016). Den förste grammatikern finner runt 1150 detta skriftsystem alltför inexakt som bas för en lärd bokkultur, men kan samtidigt förutsätta så god kännedom hos läsaren om svårigheterna med att tolka runor att han inte närmare behöver förklara vari dessa svårigheter ligger: 'det är inte runornas förtjänst, utan snarare din egen, om du läser dem väl eller tolkar dem väl utifrån vad som är sannolikt i fall där runorna ger oklart besked'. I det följande ger jag ett kort sammandrag av relevanta diskussioner från Males (2016, 2020), för att visa hur en korrekt semantisk analys av passagen i den Första grammatiska avhandlingen öppnar för en förståelse av skiftande attityder gentemot runor bland isländska lärda i perioden ca 1150-1350.

Den förste grammatikern var aktiv i en tid då fundamenten för en lärd bokkultur lades. Hans diskussion är främst av pragmatisk karaktär, även om hans ortografiska system förblev outnyttjat. 100 år senare hade den litterära självmedvetenheten vaknat, och historisk särart hade blivit en tillgång i uppbyggnaden av en isländsk och nordisk identitet. $\mathrm{Nu}$ var strategin den motsatta. När Óláfr Pórðarson hvítaskáld översatte Priscianus Institutiones i den Tredje grammatiska avhandlingen (ca 1250) ersatte han latinska bokstäver med runor. Han jämförde också runor med andra skriftsystem, och hans val är talande: När han vill belysa enskilda drag hos runorna jämför han dem med latinsk skrift, men när han argumenterar för hur förträffliga de är åberopar han grekiska och 
hebreiska. Han säger exempelvis att runorna är sexton, precis som hos de äldsta grekerna, och att när runmästarna behövde en runa för $/ y /$ tog de den från hebreiska - en förklaring som tycks vara grundad på den isländska formen på runan, $\mathfrak{I}$, till skillnad från den norska $\downarrow$ eller andra varianter (Males 2020: 183). Gång på gång undlåter han också att nämna olikheter mellan runor och latinsk skrift som kunde föranleda tvivel om runornas ypperlighet. Läsaren skall av detta förstå att runorna är lika bra som - och mer ursprungliga än - sina latinska motsvarigheter. På så vis gör han för runor vad han i den andra delen av avhandlingen gör för inhemsk poesi. Där påstår han att västnordisk diktning kom från Troja utan översättning, medan romarna fick nöja sig med översättningar gjorda i Aten. Därefter byter han ut alla latinska poetiska exempel i den efterföljande texten - en översättning av Donatus Barbarismus - mot isländska strofer, och återställer på så vis avhandlingen till den form den borde ha haft om den hade varit författad i Troja. I sitt bruk av runor och poesi är den Tredje grammatiska avhandlingen kanske det mest vältaliga vittnet till det isländska 1200-talets uppbyggnad av en ärbar forntid, ett projekt som i sin iver och sina ambitioner närmast kan beskrivas som protogöticistisk.

Runt 1350 hade situationen på Island åter förändrats, och det var nu oftare munkar än lärda hövdingar med världsliga intressen som var tongivande för den litterära produktionen. Litteraturen med alla dess grenar var sedan länge etablerad och behövde inte längre försvaras i förhållande till latinet. Arbetet med att avskriva den Tredje grammatiska avhandlingen föranledde vid denna tid en anonym munk att sammanfatta sina intryck av texten. Han skriver bland annat:

Skal yðr sýna hinn fyrsta letrshátt svá ritinn eptir sextán stafa stafrófi í danskri tungu, eptir pví sem Póroddr rúnameistari ok Ari prestr hinn fróði hafa sett 1 móti látínumanna stafrófi, er meistari Priscianus hefir sett. Hafa peir pví fleiri hljóðsgreinir með hverjum raddarstaf sem pessi er tungan fátalaðri, svá at pat má undirstanda með hljóði umbeygilegu, hvǫssu ok sljófu, svá at einnar tíðar fall væri í hváru tveggja stafrófi, til pess at skáldin mætti pá mjúkara kveða eptir nýfundinni letrlist [...] (Björn M. Ólsen 1884: 154-55)

'Nu skall ni få se det första sättet att skriva, upptecknat enligt det sextonstaviga alfabetet på danska [= norrönt], enligt det som runmästaren Póroddr och prästen Ari har fastställt gentemot de latintalandes alfabet, som mäster Priscianus har fastställt. De [runorna] har flera accenter för varje vokal i den mån som detta språk [norrönt] har färre ljud, så att man kan förstå det [en vokal] med cirkumflex eller akut eller grav accent, så att det blir en och samma 
accent i båda alfabeten, för att poeterna skulle kunna framföra [sina dikter] mjukare enligt den nyfunna bokstavskonsten [...]'. ${ }^{12}$

Påståendet att norrönt har färre vokalljud än latin kan framstå som förvånande, men är grundat på en uppfattning om att varje latinsk vokal hade en av tre accenter, så att deras antal därigenom tredubblades, och på en sammanblanding av tecken och ljud som var vanlig under medeltiden. Det som är avgörande i detta sammanhang är dock att denne munk helt bortser från Óláfrs huvudsakliga budskap, nämligen att runorna är äldre än latinsk skrift och överlag förträffliga. I fråga om runornas antal hänvisar vår munk inte till de äldsta grekerna, utan till två auktoriteter från 1100-talet. Vad gäller hans något oklara tankar om accenter är åtminstone så mycket tydligt han menar att en överföring av accenter från latinsk skrift till runor innebär en uppgradering av runskriften som leder till att poeterna kan dikta mer behagligt (förvirringen mellan tecken och ljud är här fullständig). Runskriften är alltså dels ung och kan dels förbättras genom anpassning till latin. Detta är raka motsatsen till vad Óláfr påstår. Detsamma gäller när vår munk något tidigare hänvisar till Óláfrs poetik. Här finns ingen trojansk ursprunglighet, utan tvärtom ný skáld og frœðimenn 'nya diktare och lärda' som korrigerar de äldre diktarnas villfarelser. Trots att han visar stor uppskattning för Óláfrs avhandling har han

\footnotetext{
${ }^{12}$ Översättningen av denna passage bjuder på åtskilliga svårigheter. En av dessa har föranlett utgivaren att rätta 'fátalaðri' (med färre ljud) till 'fástafaðri' (med färre bokstäver), eftersom norrönt hade fler vokaler än latin (Björn M. Ólsen (utg.) 1884: 154, 306; se diskussion i Fritzner 1883-96, 1: 395; men rättelsen godtas i 4: 93). Denna passage grundar sig dock på den Tredje grammatiska avhandlingen, och olikheten i antal vokalfonem i de två språken hör till de skillnader som undertrycks i den texten. Vidare är rättelsen svår att försvara på grund av att texten är samtida eller nästan samtida med handskriften, att rättelsen inte motiveras av något vanligt skrivarfel och att den resulterar i ett hapax legomenon (Males 2013:41-53,58). Det vår munk menar med 'färre ljud' är istället att runorna saknar accenter, enligt vad han just har sagt. En annan komplikation är uttrycket einnar tíðar fall, som bokstavligen betyder 'en tids fall' och här har översatts med 'en och samma accent'. Bakgrunden till detta uttryck är komplex, eftersom dess innebörd och dess form inte kommer från samma text. Innebörden tycks komma från det lika men inte identiska tíðar tilfelli 'tidens fall' som återfinns i avsnittet om accent i den Tredje grammatiska avhandlingen, men som där nämns som en sidokommentar om kvantitet (Björn M. Ólsen 1884: 55-56). Dess placering i kapitlet om accent verkar ha föranlett vår munk att använda tíðar fall för att beteckna accent. I sin faktiska språkliga realisering härrör dock uttrycket einnar tídar fall från en annan text som han arbetade med, nämligen Háttatal 10: Í peima hatti skal velja saman pau orðtǫk er ólíkust sé at greina ok hafi pó einnar tíðar fall bжðði orð ef vel skal vera ('i detta versmått [refhvorf] skall man sätta samman de uttryck som skiljer sig mest i betydelse men som, om det är väl utfört, har samma kvantitet [alltså upptar samma antal metriska positioner]') (Faulkes 2007: 11).
} 
härigenom motsagt hela dess andemening - dess högstämda chauvinism klingade ohörd för en som var trygg i sin egen textkultur.

Denna kronologiska följd av isländska attityder till runor är ett värdefullt och sällsynt komplement till studiet av faktiska inskrifter. Utrensningen av betydelsen 'bokstav' är alltså inte bara av lexikografiskt och forskningshistoriskt intresse, utan ger oss också tillgång till omdömen om runor som fälldes av dem som under högmedeltiden var Nordens främsta teoretiker kring det egna språket och skriften.

\section{Referenser}

\section{Primärlitteratur}

Björn M. Ólsen (utg.), 1884: Den tredje og fjærde grammatiske afhandling i Snorres Edda tilligemed de grammatiske afhandlingers prolog og to andre tillæg. Skrifter 12. København.

Clunies Ross, Margaret, et al. (utg.), 2007-: Skaldic Poetry of the Scandinavian Middle Ages. Turnhout.

Faulkes, Anthony (utg.), 2007: Snorri Sturluson. Edda. Háttatal. Andra utgåvan. London.

Hreinn Benediktsson (utg.), 1972: The First Grammatical Treatise. Introduction, Text, Notes, Translation, Vocabulary, Facsimiles. University of Iceland Publications in Linguistics 1. Reykjavík.

Larsson, Ludvig (utg.), 1885: Isländska handskriften $N^{\circ} 6454^{\circ} i$ den Arnamagnaanska samlingen på universitetsbiblioteket $i$ Kobenhavn, 1: Handskriftens äldre del. Lund.

de Leeuw van Weenen, Andrea (utg. och utg. faks.), 1993: The Icelandic Homily Book. Perg. $154^{\circ}$ in the Royal Library, Stockholm. ÍH quarto 3. Reykjavík.

Meissner, Rudolf (utg.), 1910: Rómveriasaga (AM 595, 4º). Palaestra 88. Berlin.

\section{Sekundärlitteratur}

Björn M. Ólsen, 1883: Runerne i den oldislandske literatur. København.

Bosworth, Joseph \& Toller, T. Northcote,1898: An Anglo-Saxon Dictionary. Based on the Manuscript Collections of the Late Joseph Bosworth. Oxford.

Finnur Jónsson, 1931: Lexicon Poeticum. Andra utgåvan. København.

Fritzner, Johan, 1883-96: Ordbog over det gamle norske Sprog 1-3. Kristiania. + 4: Rettelser og tillegg, utg. Finn Hødnebø. Oslo 1972.

Graff, Eberhard Gottlieb, 1834-42: Althochdeutscher Sprachschatz 1-6. Berlin. Grosse, Rudolf (utg.), 1952-: Althochdeutsches Wörterbuch. Berlin. 
Hagland, Jan Ragnar, 1989: Islands eldste runetradisjon i lys av nye funn frå Trondheim og Bergen. Arkiv för nordisk filologi 104, s. 89-102.

Jón Sigurðsson et al. (utg.), 1848-80: Edda Snorra Sturlusonar. Edda Snorronis Sturlai 1-3. Hafniæ.

Källström, Magnus, 2007: Mästare och minnesmärken. Studier kring vikingatida runristare och skriftmiljöer i Norden. Acta Universitatis Stockholmensis. Stockholm Studies in Scandinavian Philology. New Series 43. Stockholm.

Liestøl, Aslak, 1964. Runer fra Bryggen. Särtryck av Viking (1963). Bergen.

Males, Mikael, 2013: Wormianusredaktören: Språk, tro och sanning vid 1300-talets mitt. Arkiv för nordisk filologi 128, s. 41-77.

-, 2016: Applied Grammatica: Conjuring up the Native Poetae. I Intellectual Culture, utg. Stefka G. Eriksen, s. 263-307. Turnhout.

—, 2020: The Poetic Genesis of Old Icelandic Literature. Berlin.

Ordbog over det norrøne prosasprog. København: Den Arnamagnæanske Kommission. Länk: https://onp.ku.dk/onp.

Schade, Oskar, 1882: Altdeutsches Wörterbuch 1-2. Andra utgåvan. Halle.

Spurkland, Terje, 2000: I begynnelsen var futhark. Norske runer og runeinnskrifter. Oslo.

Söderwall, K. F., 1884-1918: Ordbok öfver svenska medeltids-språket. Lund. + Supplement, utg. Karl Gustav Ljunggren \& Elias Wessén. Lund 1953-73.

Pórgunnur Snædal, 2011: Rúnum ristir gripir frá Alpingisreitnum og Urriðakoti. Árbók Hins íslenska fornleifafélags 102, s. 167-186.

\begin{abstract}
This article argues that Old Norse rúnar cannot have the unqualified meaning 'letters', but only 'runes' or, rarely, 'another type of script than the ordinary'. The meaning 'letters' in dictionaries and translations is derived from Latin, which has no word for 'runes', and where the natural translation of rúnar is therefore litterae 'letters'. When Latin translations were subsequently reverted into the vernacular, the additional meaning 'letters' entered scholarly literature on the subject. This is true not only of Old Norse, but also of Old English and Old High German. This observation can provide us with more secure readings of some textual passages and, more importantly, allows us to follow the expression of attitudes towards runes in Iceland in the period c. 1150-1350.
\end{abstract}

Keywords: rún, letter, semantics, First Grammatical Treatise

Mikael Males

Universitetet $i$ Oslo

Institutt for lingvistiske og nordiske studier

Niels Henrik Abels vei 36, 0313, Oslo

mikael.males@iln.uio.no 


\section{Recension}

Karl G. Johansson och Elise Kleivane (red.). Speculum septentrionale. Konungs skuggsjá and the European Encyclopedia of the Middle Ages. Bibliotheca Nordica 10. Oslo: Novus forlag, 2018. 328 s.

Under 2018 utkom boken Speculum septentrionale. Konungs skuggsjá and the Encyclopedia of the Middle Ages, redigerad av Karl G. Johansson och Elise Kleivane. Det är en artikelsamling med fokus på Konungs skuggsjá. Bakgrunden till artikelsamlingen är en föreläsningsserie vid Universitetet i Oslo om encyklopedisk litteratur under 1200-talet, följd av en konferens om Konungs skuggsjá. Boken består till största delen av bidrag från dessa evenemang, men ytterligare artiklar har lagts till dessa. Artiklarna är ämnesmässigt spridda, från beskrivningar och diskussioner av handskrifterna med Konungs skuggsjá till undersökningar ur ett historiskt och idéhistoriskt perspektiv. Tillsammans ger dessa artiklar en god överblick över forskningsläget kring detta verk. I denna recension ges inledningsvis en kortfattad sammanfattning av samtliga artiklar som ingår i boken, och därefter behandlas tre av dessa mer utförligt.

I Karl G. Johanssons och Elise Kleivanes inledande uppsats Konungs skuggsjá and the Interplay between Universal and Particular, ges en bred introduktion till detta verk. Här diskuteras handskriftsförhållanden, verkets europeiska bakgrund och liknande. Denna artikel behandlas utförligare nedan. Mary Franklin-Browns artikel, Wonders at the End of the World: The Time of Marvels in Gerald of Wales's Topographia Hibernica, behandlar som titeln antyder Gerald of Wales' beskrivning av Irland, och hur de märkligheter man menade fanns där placeras in i en europeisk lärdomskontext. Alfred Hiatt, Quasi in Speculo: Maps and Geographical

Mårtensson, Lasse. 2021. Rec. av Karl G. Johansson och Elise Kleivane (red.). Speculum septentrionale. Konungs skuggsjá and the European Encyclopedia of the Middle Ages.

Scripta Islandica 72: 137-142.

(C) Lasse Mårtensson (CC BY)

DOI: $10.33063 /$ diva-439405 
Thought in the Thirteenth and Fourteenth Centuries, diskuterar geografiskt tänkande och världsbilden under medeltiden. Dale Kedwards skriver i The World Image of the Konungs skuggsjá om den världsbild som beskrivs i Konungs skuggsjá. Han behandlar bl.a. de klimatzoner som man räknade med i medeltidens världsbild, och hur Norden placerades in $\mathrm{i}$ denna kontext. Hanteringen av Grönland i detta sammanhang ges särskild uppmärksamhet. Karl G. Johansson behandlar de äldsta handskrifterna med Konungs skuggsjá i artikeln Konungs skuggsjá and the Earliest Fragments - A Key to New Insights into Norwegian Literate Culture. Denna artikel behandlas utförligare nedan. Elise Kleivanes bidrag heter There is More to Stjorn than Biblical Translation. Även denna behandlas utförligare nedan.

Sverrir Jakobsson skriver i artikeln Prester John at the Norwegian Court: The Learned Discourse about the Indies in Old Norse Sources om bilden av Indien i det medeltida Västnorden. Indien sågs som en plats för stora rikedomar, monster, ett östligt kristet kungadöme (Johannes prästen) och till och med själva Paradiset. Utifrån huvudsakligen det irländska verket De duodecim abusiuis saeculi skriver Elizabeth Boyle om kungateori under medeltiden. Artikeln heter Biblical Kings and Kingship Theory in Medieval Ireland and Norway. Bland annat beskrivs hur kung David och Kyros II ("den store") används som exempel i fråga om kungars agerande. I artikeln Composition and Social Structure in Konungs skuggsjá diskuterar Sverre Bagge den bild av samhället som ges i Konungs skuggsjá. Alessia Bauer bidrar med artikeln Encyclopaedic Tendencies and the Medieval Educational Programme: The Merchant's Chapter of Konungs skuggsjá. Här behandlas avsnittet om handelsmannen, och de encyklopediska tendenser som återfinns där. Hon framhåller att författaren av Konungs skuggsjá här tar upp flera aspekter som faller inom medeltidens utbildningsprogram, trivium och quadrivium, även om det inte görs på ett sätt som fullt ut svarar mot utbildningsprogrammet. Hans Jacob Orning diskuterar i artikeln The Konungs skuggsjá and the Emergence of a New Elite in Thirteenth-Century Norway bl.a. hur Konungs skuggsjá introducerar och behandlar konceptet hæverska, och hur detta representerade något nytt $\mathrm{i}$ tidens samhälle.

Karl G. Johanssons och Elise Kleivanes inledande uppsats, Konungs skuggsjá and the Interplay between Universal and Particular, är som nämnts en introduktion till Konungs skuggsjá. Den fungerar som en pedagogiskt väl utformad introduktion till de mer detaljerade studier som följer. Johansson och Kleivane diskuterar bl.a. den tredelning som ofta 
har gjorts av detta verk, i en del om handelsmannen, en om hirdmannen och en om kungen. Det finns också en prolog, men den är enbart bevarad i yngre isländska handskrifter. Johansson och Kleivane poängterar dock att den nämnda tredelningen av innehållet inte finns tydligt markerad i huvudhandskriften, AM $243 \mathrm{~b} \alpha$ fol. Den initial som inleder kungadelen har en storlek av tre rader, och sådana initialer finns det flera av, utan att de markerar ett nytt avgränsat innehåll. Den kodikologiska gränsen mellan hirdmansdelen och kungadelen är därmed inte lika tydlig som den mellan exempelvis köpmansdelen och hirdmansdelen, och inte heller textmässigt finns en lika tydlig avgränsning. Johansson och Kleivane menar att man istället bör räkna med en tvådelning av innehållet i Konungs skuggsjá. De menar också att det inte finns något innehållsligt hinder till att prologen, bevarad i yngre handskrifter, kan ha funnits med i det ursprungliga verket. Det är istället det faktum att den har bevarats i yngre handskrifter som gör att man skulle kunna anta att den är yngre.

Johansson och Kleivane sätter också in Konungs skuggsjá i ett europeiskt genreperspektiv. Detta verk knyter an till genren Fürstenspiegel/ Mirror of Princes, med flera representanter på europeisk botten. Ett sådant exempel är Policraticus (1159) av John of Salisbury. Samtidigt framhålls att Konungs skuggsjá inte är formad efter en enskild förebild, utan den utgör en kombination av internationell och inhemsk lärdom. Man konstaterar vidare att författaren är anonym, och inte heller går det att bestämma exakt när verket har tillkommit. Johansson och Kleivane ger också en inspirerande översikt, utifrån aktuell forskning, över den litterära miljön i Norge under 1200-talet, dvs. den runt Hákon Hákonarson, hans barn och barnbarn, som genererade en rik översättningsverksamhet av verk på latin, franska och tyska. Många av dessa verk är bevarade i yngre, isländska handskrifter, men Konungs skuggsjá, tillsammans med t.ex. Strengleikar, finns bevarad i handskrifter från 1200-talet.

Avslutningsvis ger Johansson och Kleivane en beskrivning av de handskrifter som innehåller Konungs skuggsjá, och Johansson gör sedan en fördjupad granskning av de äldsta fragmenten (se nedan). De redogör också för de utgåvor av Konungs skuggsjá som finns.

Karl G. Johansson bidrar som nämnts också med artikeln Konungs skuggsjá and the Earliest Fragments - A Key to New Insights into Norwegian Literate Culture. Hans huvudsyfte är att undersöka vilken information dessa fragment ger om den tidiga spridningen av Konungs skuggsjá, och om de miljöer där textvittnena skrevs ned. Som huvudhandskrift för Konungs skuggsjá framhålls ofta AM 243 b $\alpha$ fol., och dess position 
som huvudhandskrift kommer bl.a. av att den är det mest omfattande textvittnet, medan de övriga tidiga textvittnena är fragment. Fragmenten som behandlas är följande: NRA 58 A, NRA 58 B och NRA 58 C, varav den sistnämnda från början utgjorde en del av samma handskrift som NKS 235 g 4to. En viktig utgångspunkt för Johanssons artikel är Ludvig Holm-Olsens undersökning av Konungs skuggsjá (1952, Håndskriftene av Konungs skuggsjá; Bibliotheca Arnamagnæanæ 13), och hans stemma för handskrifterna återges. Den isländska traditionen, som ligger inom den s.k. A-gruppen hos Holm-Olsen, lämnas därhän i artikeln, och fokus ligger på det norska handskriftsunderlaget. Johansson understryker att det stemma Holm-Olsen ställer upp förutsätter en talrik reproduktion av Konungs skuggsjá under en relativt kort period efter verkets antagna tillkomst.

Johansson beskriver handskrifterna kodikologiskt och paleografiskt, och diskuterar proveniensfrågan. Fragmentet NRA 58 A, som i stemmat utgör en egen gren, har sannolikt tillkommit i sydvästra Norge, eventuellt nära Bergen. Fragmentet NRA 58 B är det enda textvittnet av de behandlade som tillhör Holm-Olsens A-grupp (i övrigt isländska handskrifter). Detta textvittne ska ha skrivits av en norsk skrivare, även om texten i övrigt knyter an till den isländska traditionen. Johansson nämner möjligheten att detta textvittne utgör utgångspunkten för den isländska grenen i Konungs skuggsjá-traditionen. Fragmentet NRA 58 C/NKS 235 g 4to är textmässigt nära kopplat till huvudhandskriften AM $243 \mathrm{~b} \alpha$ fol. I sitt stemma anger Holm-Olsen att AM 243 b $\alpha$ fol. är en avskrift av NRA 58 C/NKS 235 g 4to. De visar också upp kodikologiska och paleografiska likheter, och troligtvis har de tillkommit i samma miljö. De två skrivarhänder som har producerat NRA $58 \mathrm{C} / \mathrm{NKS} 235$ g 4to visar dock upp östnorska drag, medan skrivarhanden i AM 243 b $\alpha$ fol. har sydvästliga drag. Johansson konstaterar att de äldsta textvittnena har utgjort prakthandskrifter, och att detta tyder på att Konungs skuggsjá åtnjöt hög prestige.

Johanssons diskussion av de aktuella textvittnena är god syntes av det som har skrivits tidigare, och han gör flera intressanta nya observationer. Det jag dock saknar i beskrivningarna och diskussionerna av paleografi och kodikologi är bilder och illustrationer. Sådana är till stor hjälp för läsaren när det gäller att ta ställning till likheter och skillnader i fråga om skrivteckens utformning.

I Elise Kleivanes artikel There is More to Stjórn than Biblical Translation ligger fokus på den s.k. Stjórn 3. Stjórn 3 är en översättning av Josua, Domarboken, Rut, 1 Samuelsboken, 2 Samuelsboken, 1 Kungaboken och 2 Kungaboken. Texten följer Vulgata rätt nära. Stjórn 1 är en 
kommenterad översättning av 1 Mosebok och 2 Mosebok fram till kap. 18. Kommentarerna, huvudsakligen från Speculum historiale och Historia scholastica, gör att texten är avsevärt längre än Vulgata. Stjórn 2 är en kortfattad återgivning av delar av återstoden av Pentateuken. Slutligen finns också en Stjórn 4, som utgörs av en avvikande version av Josua i förhållande till den som föreligger i Stjórn 3.

Kleivane påpekar att den bild man kan få i utgåvor av Stjórn (t.ex. den av C. R. Unger från 1862 eller den av Reidar Astås från 2009), dvs. att det är fråga om ett sammanhållet verk från 1 Mosebok till 2 Kungaboken, inte stämmer överens med hur texterna är utformade. Stjórn 1, 2 och 3 är tre skilda verk med olika funktioner, där de norröna texterna förhåller sig på olika sätt till Vulgata. Kleivane karaktäriserar Stjórn 1 som en världshistoria ante legem, dvs. innan Moses får lagen vid Sinai. (Stjórn 1 slutar som nämnts i 2 Mosebok, kap. 18.) Stjórn 3 beskriver Kleivane som en kungaspegel, med Saul, David och Salomo som centrala gestalter. Hon framhåller också att Stjórn 3 fungerar väl som ett autonomt verk, och att det inte bara är tänkbart som en fortsättning på Pentateuken. Kleivane nämner att Stjórn 1 inte finns bevarad i norska handskrifter, utan endast i isländska, medan Stjórn 3 finns bevarad i fragment med åtminstone möjlig norsk proveniens. Prologen sätter in Stjórn 1 i en norsk kontext, med kung Hákon Magnússon som initiativtagare, men Kleivane påpekar att texten kan ha tillkommit antingen i Norge eller på Island.

Stjórn 2 finns bara i ett textvittne, nämligen ett lägg inlagt i AM 226 fol. Kleivane nämner förslaget att Stjórn 2 kan ha tillkommit för att fylla luckan mellan Stjórn 1 och Stjórn 3, i syfte att infogas i AM 226 fol.

Tidigare forskning har tolkat slutet på Stjórn 1 i 2 Mosebok 18 som att verket är oavslutat. Kleivane tar även upp den tråden, och argumenterar för att den faktiskt kan vara komplett som den är. Om syftet med Stjórn 1 är att vara en världshistoria ante legem är återstoden av Pentateuken av mindre relevans. Dessutom kan man ha uppfattat att lagen, som får ett stort utrymme i återstoden av Pentateuken, var av mindre vikt i medeltidens Skandinavien, där man levde sub gratia. Kleivane framhåller också att den fornsvenska Pentateukparafrasen, en parafraserande översättning av Moseböckerna, följer samma mönster som Stjórn 1 och 2: en rikt kommenterad text i 1 Mosebok och inledningen av 2 Mosebok, medan återstoden av Pentateuken är kraftigt förkortad. Hon menar att det inte behöver bero på direkt påverkan mellan de två verken, utan på att man var och en för sig har behandlat de olika delarna av Pentateuken på samma sätt. Kleivanes tolkning av Stjórn 2 är att den är ett utslag av en 
senmedeltida syn på Bibeln som en mer fixerad text, och att den är en del av den tendens som ledde till fullständiga biblar på folkspråk under senmedeltiden i t.ex. Tyskland, Frankrike och England.

Även den medeltida danska bibelöversättningen tas upp, vilken börjar på 1 Mosebok och slutar med 2 Kungaboken 23:18, dvs. ungefär där Stjórn 3 slutar. Den danska översättningen skiljer sig från Stjórn 1 och inledningen av Pentateukparafrasen i det att den är en textnära översättning av Vulgata, utan tillägg.

Kleivanes artikel är ett intressant bidrag till forskningen om den medeltida bibelöversättningen i Norden. Hon visar upp en stor beläsenhet på området, och hon ger en välformulerad sammanfattning av forskningsläget, och bidrar med viktig ny kunskap på området. Viktiga exempel på det senare gäller frågan om autonomin hos Stjórn 3, och funktionen hos Stjórn 2.

Lasse Mårtensson

Uppsala universitet

Institutionen för nordiska språk

ORCID iD 0000-0001-5072-4961 


\section{Författarna i denna årgång}

Frog, PhD, Docent, Academy of Finland Researcher, University of Helsinki, Folklore Studies / Department of Cultures, ORCID ID 00000001-5967-6281.

Felix Lummer, PhD Candidate, University of Iceland, School of Social Sciences, Faculty of Sociology, Anthropology and Folkloristics, ORCID iD 0000-0002-6867-8921.

Mikael Males, førsteamanuensis, Universitetet i Oslo, Institutt for lingvistiske og nordiske studier.

Lasse Mårtensson, professor, Uppsala universitet, Institutionen för nordiska språk, ORCID iD 0000-0001-5072-4961.

Martin Ringmar, Fil. mag., universitetsadjunkt, Lunds universitet, Språkoch litteraturcentrum. 



\section{Scripta Islandica ISLÄNDSKA SÄLLSKAPETS ÅRSBOK}

ÅRGÅNG 1 · 1950: Einar Ól. Sveinsson, Njáls saga.

ÅRGÅNG 2 - 1951: Chr. Matras, Det færøske skriftsprog af 1846.-Gösta Franzén, Isländska studier i Förenta staterna.

ÅRGÅNG 3 - 1952: Jón Aðalsteinn Jónsson, Biskop Jón Arason.-Stefan Einarsson, Halldór Kiljan Laxness.

ÅRGÅNG 4 · 1953: Alexander Jóhannesson, Om det isländske sprog.-Anna Z. Osterman, En studie över landskapet i Voluspá.-Sven B. F. Jansson, Snorre. ÅRGÅNG 5 · 1954: Sigurður Nordal, Tid och kalvskinn.-Gun Nilsson, Den isländska litteraturen i stormaktstidens Sverige.

ÅRGÅNG 6 · 1955: Davíð Stefánsson, Prologus till »Den gyllene porten».— Jakob Benediktsson, Det islandske ordbogsarbejde ved Islands universitet.Rolf Nordenstreng,Volundarkviða v. 2.-Ivar Modéer, Över hed och sand till Bæjarstaðarskogur.

ÅRGÅNG 7 · 1956: Einar Ól. Sveinsson, Läs-och skrivkunnighet på Island under fristatstiden._Fr. le Sage de Fontenay, Jonas Hallgrimssons lyrik.

ÅRGÅNG 8 - 1917: Porgils Gjallandi (Jón Stefánsson), Hemlängtan._Gösta Holm, I fågelberg och valfjära. Glimtar från Färöarna.-Ivar Modéer, Ur det isländska allmogespråkets skattkammare.

ÅRGÅNG 9 · 1958: K.-H. Dahlstedt, Isländsk dialektgeografi. Några synpunkter.-Peter Hallberg, Kormáks saga.

ÅRGÅNG 10 · 1959: Ivar Modéer, Isländska sällskapet 1949-1959._Sigurður Nordal, The Historical Element in the Icelandic Family Sagas._Ivar Modéer, Johannes S. Kjarval.

ÅRGÅNG 11 · 1960: Sigurd Fries, Ivar Modéer 3.11.1904-31.1.1960.Steingrímur J. Porsteinsson, Matthías Jochumsson och Einar Benediktsson.Ingegerd Fries, Genom Ódáđahraun och Vonarskarð - färder under tusen år.

ÅRGÅNG 12 · 1961: Einar Ól. Sveinsson, Njáls saga.

ÅRGÅNG 13 - 1962: Halldór Halldórsson, Kring språkliga nybildningar i nutida isländska.-Karl-Hampus Dahlstedt, Gudruns sorg. Stilstudier över ett eddamotiv.-Tor Hultman, Rec. av Jacobsen, M. A.-Matras, Chr., Föroyskdonsk orðabók. Færøsk-dansk ordbog.

ÅRGÅNG 14 - 1963: Peter Hallberg, Laxness som dramatiker.-Roland Otterbjörk, Moderna isländska förnamn.-Einar Ól. Sveinsson, Från Mýrdalur.

ÅRGÅNG 15 · 1964: Lars Lönnroth, Tesen om de två kulturerna. Kritiska studier i den isländska sagaskrivningens sociala förutsättningar._Valter Jansson, Bortgångna hedersledamöter.

ÅRGÅNG 16 · 1965: Tryggve Sköld, Isländska väderstreck. 
ÅRGÅNG 17 - 1966: Gun Widmark, Om nordisk replikkonst i och utanför den isländska sagan.-Bo Almqvist, Den fulaste foten. Folkligt och litterärt i en Snorri-anekdot.

ÅRGÅNG 18 · 1967: Ole Widding, Jónsbóks to ikke-interpolerede håndskrifter. Et bidrag til den isländske lovbogs historie.-Steingrimur J. Porsteinsson, Jóhann Sigurjónsson och Fjalla-Eyvindur.

ÅRGÅNG 19 - 1968: Einar Ól. Sveinsson, Eyrbyggja sagas kilder.-Svávar Sigmundsson, Ortnamnsforskning på Island.-Lennart Elmevik, Glömskans häger. Till tolkningen av en Hávamálstrof.-Berättelsen om Audun, översatt av Björn Collinder.

ÅRGÅNG 20 - 1969: Sveinn Höskuldsson, Skaldekongressen på Parnassen - en isländsk studentpjäs._Evert Salberger, Cesurer i Atlakviða.

ÅRGÅNG 21 · 1970: Davíð Erlingsson, Etiken i Hrafnkels saga Freysgoða._Bo Almqvist, Isländska ordspråk och talesätt.

ÅRGÅNG 22 · 1971: Valter Jansson, Jöran Sahlgren. Minnesord.-Lennart Elmevik, Ett eddaställe och några svenska dialektord.-Bjarne Beckman, Hur gammal är Hervararsagans svenska kungakrönika?-Baldur Jónsson, Några anmärkningar till Blöndals ordbok. - Evert Salberger, Vel glýioð eller velglýioð. En textdetalj i Vǫluspá 35.-Anna Mörner, Isafjord.

ÅRGÅNG 23 · 1972: Bo Ralph, Jon Hreggviðsson-en sagagestalt i en modern isländsk roman.-Staffan Hellberg, Slaget vid Nesjar och »Sven jarl Håkonsson».-Thorsten Carlsson, Norrön legendforskning-en kort presentation.

ÅRGÅNG 24 · 1973: Peter Hallberg, Njáls saga-en medeltida moralitet?Evert Salberger, Elfaraskáld - ett tillnamn i Njáls saga._Richard L. Harris, The Deaths of Grettir and Grendel: A New Parallel.-Peter A. Jorgensen, Grendel, Grettir, and Two Skaldic Stanzas.

ÅRGÅNG 25 · 1974: Valter Jansson, Isländska sällskapet 25 år.-Ove Moberg, Bröderna Weibull och den isländska traditionen._Evert Salberger, Heill pú farir! Ett textproblem i Vafprúđnismál 4._Bjarne Beckman, Mysing._Hreinn Steingrímsson, »Að kveða rímur».-Lennart Elmevik, Två eddaställen och en västnordisk ordgrupp.

ÅRGÅNG 26 · 1975: Björn Hagström, Att särskilja anonyma skrivare. Några synpunkter på ett paleografiskt-ortografiskt problem i medeltida isländska handskrifter, särskilt Isländska Homilieboken._Gustaf Lindblad, Den rätta läsningen av Isländska Homilieboken.-Bo Ralph, En dikt av Steinpórr, islänning._Kristinn Jóhannesson, Från Värmland till Borgarfjörður. Om Gustaf Frödings diktning i isländsk tolkning.

ÅRGÅNG 27 · 1976: Alan J. Berger, Old Law, New Law, and Hœnsa-Póris saga.-Heimir Pálsson, En översättares funderingar. Kring en opublicerad översättning av Sven Delblancs Åminne.-Kunishiro Sugawara, A Report on Japanese Translations of Old Icelandic Literature.-Evert Salberger, Ask Burlefot. En romanhjältes namn._Lennart Elmevik, Fisl. giogurr. 
ÅRGÅNG 28 · 1977: Gustaf Lindblad, Centrala eddaproblem i 1970-talets forskningsläge. - Bo Ralph, Ett ställe i Skáldskaparmál 18.

ÅRGÅNG 29 · 1978: John Lindow, Old Icelandic páttr: Early Usage and Semantic History._Finn Hansen, Naturbeskrivende indslag i Gísla saga Súrssonar._Karl Axel Holmberg, Uppsala-Eddan i utgåva.

ÅRGÅNG 30 · 1979: Valter Jansson, Dag Strömbäck. Minnesord.-Finn Hansen, Benbrud og bane i blåt.-Andrea van Arkel, Scribes and Statistics. An evaluation of the statistical methods used to determine the number of scribes of the Stockholm Homily Book._Eva Rode, Svar på artiklen »Scribes and Statistics».-Börje Westlund, Skrivare och statistik. Ett genmäle.

ÅRGÅNG 31 · 1980: Björn Högström, Fvn. bakkakolfr och skotbakki. Några glimtar från redigeringen av en norrön ordbok.-Alan J. Berger, The Sagas of Harald Fairhair.-IIkka Hirvonen, Om bruket av slutartikel i de äldsta norröna homilieböckerna IsIH och GNH.-Sigurgeir Steingrimsson, Tusen och en dag. En sagosamlings vandring från Orienten till Island._Jan Terje Faarlund, Subject and nominative in Oid Norse.-Lars-Erik Edlund, Askraka-ett engångsord i Egilssagan.

ÅRGÅNG $32 \cdot$ 1981: Staffan Hellberg, Kungarna i Sigvats diktning. Till studiet av skaldedikternas språk och stil._Finn Hansen, Hrafnkels saga: del og helhed.Ingegerd Fries, Njals saga 700 år senare.

ÅRGÅNG 33 - 1982: Jan Paul Strid, Veiðar námo-ett omdiskuterat ställe i Hymiskviða._Madeleine G. Randquist, Om den (text)syntaktiska och semantiska strukturen i tre välkända isländska sagor. En skiss.-Sigurgeir Steingrímsson, Árni Magnusson och hans handskriftsamling.

ÅRGÅNG 34 · 1983: Peter Hallberg, Sturlunga saga - en isländsk tidsspegel.— Porleifur Hauksson, Anteckningar om Hallgrímur Pétursson.-Inger Larsson, Hrafnkels saga Freysgoða. En bibliografi.

ÅRGÅNG 35 · 1984: Lennart Elmevik, Einar Ólafur Sveinsson. Minnesord.Alfred Jakobsen, Noen merknader til Gísls páttr Illugasonar.-Karl-Hampus Dahlstedt, Bygden under Vatnajökull. En minnesvärd resa till Island 1954.Michael Barnes, Norn.-Barbro Söderberg, Till tolkningen av några dunkla passager i Lokasenna.

ÅRGÅNG 36 · 1985: Staffan Hellberg, Nesjavísur än en gång.-George S. Tate, Eldorado and the Garden in Laxness' Paradisarheimt.- Porleifur Hauksson, Vildvittror och Mattisrövare i isländsk dräkt. Ett kåseri kring en översättning av Ronja rövardotter.-Michael Barnes, A note on Faroese $/ \theta />/ \mathrm{h} /$. -Björn Hagström, En färöisk-svensk ordbok. Rec. av Ebba Lindberg \& Birgitta Hylin, Färöord. Liten färöisk-svensk ordbok med kortfattad grammatik jämte upplysningar om språkets historiska bakgrund.-Claes Åneman, Rec. av Bjarne Fidjest $\varnothing 1$, Det norrøne fyrstediktet.

ÅRGÅNG 37 - 1986: Alfred Jakobsen, Om forfatteren av Sturlu saga.-Michael $P$. Barnes, Subject, Nominative and Oblique Case in Faroese.-Marianne E. Kalinke, The Misogamous Maiden Kings of Icelandic Romance.-Carl-Otto 
von Sydow, Jon Helgasons dikt I Árnasafni. Den isländska texten med svensk översättning och kort kommentar.

ÅRGÅNG 38 · 1987: Michael P. Barnes, Some Remarks on Subordinate Clause Word-order in Faroese._Jan Ragnar Hagland, Njáls saga i 1970-og 1980-åra. Eit översyn över nyare forskning.-Per-Axel Wiktorsson, Om Torleiftåten.Karl-Hampus Dahlstedt, Davío Stefánssons dikt Konan, sem kyndir ofninn minn. Den isländska texten med svensk översättning och kort kommentar.

ÅRGÅNG 39 - 1988: Alfred Jakobsen, Snorre og geografien.-Joan TurvillePetre, A Tree Dream in Old Icelandic.-Agneta Breisch, Fredlöshetsbegreppet i saga och samhälle._Tommy Danielsson, Magnús berfættrs sista strid._Ola Larsmo, Att tala i röret. En orättvis betraktelse av modern isländsk skönlitteratur. ÅRGÅNG 40 - 1989: Alv Kragerud, Helgdiktningen og reinkarnasjonen._Jan Nilsson, Guðmundr Ólafsson och hans Lexicon Islandicum — några kommentarer. ÅRGÅNG 41 · 1990: Jan Ragnar Hagland, Slaget på Pezinavellir i nordisk og bysantinsk tradisjon. - William Sayers, An Irish Descriptive Topos in Laxdœla Saga.-Carl-Otto von Sydow, Nyisländsk skönlitteratur i svensk översättning. En förteckning. Del 1.-Karl Axel Holmberg, Rec. av Else Nordahl, Reykjavík from the Archaeological Point of View.

ÅRGÅNG 42 · 1991: Stefan Brink, Den norröna bosättningen på Grönland. En kortfattad forskningsöversikt jämte några nya forskningsbidrag.-Carl-Otto von Sydow, Två dikter av Jón Helgason i original och svensk dräkt med kommentar.Carl-Otto von Sydow, Nyisländsk skönlitteratur i svensk översättning. En förteckning. Del 2._Nils Österholm, Torleiftåten i handskriften Add 4867 fol._ Lennart Elmevik, Rec. av Esbjörn Rosenblad, Island i saga och nutid.

ÅRGÅNG 43 - 1992: Anne Lidén, St Olav in the Beatus Initial of the Carrow Psalter-Michael P. Barnes, Faroese Syntax-Achievements, Goals and Problems.-Carl-Otto von Sydow, Nyisländsk skönlitteratur i svensk översättning. En förteckning. Del 3.

ÅRGÅNG 44 · 1993: Karl Axel Holmberg, Isländsk språkvård nu och förr. Med en sidoblick på svenskan._Páll Valsson, Islands älsklingsson sedd i ett nytt ljus. Några problem omkring den nya textkritiska utgåvan av Jónas Hallgrímssons samlade verk: Ritverk Jónasar Hallgrímssonar I-IV, 1989._William Sayers, Spiritual Navigation in the Western Sea: Sturlunga saga and Adomnán's Hinba.Carl-Otto von Sydow, Nyisländsk skönlitteratur i svensk översättning. En förteckning. Del 4.

ÅRGÅNG 45 · 1994: Kristín Bragadóttir, Skalden och redaktören Jón Porkelsson.-Ingegerd Fries, När skrevs sagan? Om datering av isländska sagor, särskilt Heiðarvígasagan.-Sigurður A. Magnússon, Sigurbjörn Einarsson som student i Uppsala på 1930-talet. Översättning, noter och efterskrift av Carl-Otto von Sydow.

ÅRGÅNG 46 - 1995: Ingegerd Fries, Biskop Gissur Einarsson och reformationen._François-Xavier Dillmann, Runorna i den fornisländska litteraturen. En översikt.-William Sayers, Poetry and Social Agency in Egils saga SkallaGrímssonar. 
ÅRGÅNG 47 · 1996: Lennart Elmevik, Valter Jansson. Minnesord._Jón Hnefill Aðalsteinsson, Blot i forna skrifter.-Gísli Pálsson, Språk, text och identitet i det isländska samhället.

ÅRGÅNG 48 · 1997: Lennart Elmevik, Anna Larsson. Minnesord.-Lennart Moberg, "Stóð und árhjalmi”. Kring Hákonarmál 3:8.-Henric Bagerius, Vita vikingar och svarta sköldmör. Föreställningar om sexualitet i Snorre Sturlassons kungasagor.-Páll Valsson, En runologs uppgång och fall.-Björn Hagström, Något om färöisk lyrik - mest om Christian Matras.

ÅRGÅNG 49 · 1998: Veturliði Óskarsson, Om låneord og fremmed påvirkning på ældre islandsk sprog.-Jóhanna Barðdal, Argument Structure, Syntactic Structure and Morphological Case of the Impersonal Construction in the History of Scandinavian.-_Jan Ragnar Hagland, Note on Two Runic Inscriptions relating to the Christianization of Norway and Sweden._-William Sayers, The ship heiti in Snorri's Skáldskaparmál.- Henrik Williams, Rec. av Snorres Edda. Översättning från isländskan och inledning av Karl G. Johansson och Mats Malm.

ÅRGÅNG 50 - 1999: Lennart Elmevik, Isländska sällskapet 50 år.-Bjarni Guðnason, Guðrún Ósvifursdóttir och Laxdæla Saga.-Veturliði Óskarsson, Verbet isländskt ské.-Henrik Williams, Nordisk paleografisk debatt i svenskt perspektiv. En kort överblick._Carl-Otto von Sydow, Jón Helgasons dikt Kom milda nótt i svensk tolkning. - Veturliði Óskarsson, Är isländsk språkvård på rätt väg?-Gun Widmark, Isländsk-svenska kontakter i äldre tid.

ÅRGÅNG 51 · 2000: Lennart Elmevik, Vidar Reinhammar. Minnesord.-Peter Springborg, De islandske håndskrifter og "håndskriftsagen".-Gun Widmark, Om muntlighet och skriftlighet i den isländska sagan._Judy Quinn, Editing the Edda-the case of Vôluspá.-Kirsten Wolf, Laughter in Old Norse-Icelandic Literature.-Fjodor Uspenskij, Towards Further Interpretation of the Primordial Cow Auðhumla._Tom Markey, Icelandic sími and Soul Contracting._Björn Hagström, Den färöiska "Modersmålsordboken".

ÅRGÅNG 52 · 2001: Lennart Elmevik, Claes Åneman. Minnesord.-Lars Lönnroth, Laxness och isländsk sagatradition._François-Xavier Dillmann, Om hundar och hedningar. Kring den fornvästnordiska sammansättningen hundheiðinn.- Mindy MacLeod, Bandrúnir in Icelandic Sagas.-Thorgunn Sncedal, Snorre Sturlasson-hövding och historiker.-Guðrún Kvaran, Omkring en doktorafhandling om middelnedertyske låneord i islandsk diplomsprog frem til år 1500 .

ÅRGÅNG 53 - 2002: Veturliði Óskarsson, Studiosus antiqvitatum. Om Jón Ólafsson från Grunnavík, förebilden till Halldór Laxness sagoperson Jón Guðmundsson från Grindavik.-Pórgunnur Sncedal, From Rök to Skagafjörður: Icelandic runes and their connection with the Scandinavian runes of the Viking period._Patrik Larsson, Det fornvästnordiska personbinamnet Kikr._Veturliði Óskarsson, Ur en eddadikts forskningshistoria.

ÅRGÅNG 54 · 2003: Henrik Williams, Än lever de gamla gudarna. Vikten av att forska om fornisländska.-Anna Helga Hannesdóttir, Islänningars attityder till språkliga normer.-Kristinn Jóhannesson, Halldór Laxness-samtidens 
spegel._Fredrik Charpentier Ljungqvist, Arngrímur Jónsson och hans verk.Adolfo Zavaroni, Communitarian Regime and Individual Power: Othinus versus Ollerus and Mithothyn.

ÅRGÅNG 55 · 2004: Heimir Pálsson, Några kapitel ur en oskriven bok.Staffan Fridell, At ósi skal á stemma. Ett ordspråk i Snorres Edda.-Agneta Ney, Mö-traditionen i fornnordisk myt och verklighet._Martin Ringmar, Vägen via svenska. Om G. G. Hagalíns översättning av en finsk ödemarksroman.Svante Norr, A New Look at King Hákon's Old Helmet, the árhjálmr._Lasse Mårtensson, Två utgåvor av Jóns saga helga. En recension samt några reflexioner om utgivningen av nordiska medeltidstexter.

ÅRGÅNG 56 - 2005: Lennart Elmevik, Lennart Moberg. Minnesord._Fredrik Charpentier Ljungqvist, The Significance of Remote Resource Regions for Norse Greenland. - Andreas Nordberg, Handlar Grimnesmål 42 om en sakral måltid? Daniel Sävborg, Kormáks saga - en norrön kärlekssaga på vers och prosa.Ingvar Svanberg och Sigurður Agisson, The Black Guillemot (Cepphus grylle) in Northern European Folk Ornithology.-Staffan Fridell, At ósi skal á stemma. Ett ordspråk i Snorres Edda. 2._Else Mundal, Literacy - kva talar vi eigentleg om? - Leidulf Melve, Literacy - eit omgrep til bry eller eit brysamt omgrep?

ÅRGÅNG 57 - 2006: Theodore M. Andersson, Víga-Glúms saga and the Birth of Saga Writing._Staffan Fridell, Fvn. hrynja och fsv. rynia. Om ett eddaställe och en flock i Södermannalagen.-Kirsten Wolf, The Color Blue in Old NorseIcelandic Literature._Fredrik Charpentier Ljungqvist, Kristen kungaideologi i Sverris saga._Lars Lönnroth, Sverrir's Dreams.-Arnved Nedkvitne, Skriftkultur i skandinavisk middelalder-metoder og resultater.-Lars Lönnroth, The Growth of the Sagas. Rec. av Theodore M. Andersson, The Growth of the Medieval Icelandic Sagas (1180-1280).-Anders Hultgård, rec. av François-Xavier Dillmann, Les magiciens dans l'Islande ancienne. Études

sur la représentation de la magie islandaise et de ses agents dans les sources littéraires norroises.-Heimir Pálsson, Den stora isländska litteraturhistorian. Rec. av Íslensk bókmenntasaga I-V. Red. Vésteinn Ólason, Halldór Guðmundsson \& Guðmundur Andri Thorsson. Sigurd Fries, Jón Aðalsteinn Jónsson och studiet av nyisländskan i Sverige.

ÅRGÅNG 58 - 2007: Heinrich Beck, Die Uppsala-Edda und Snorri Sturlusons Konstruktion einer skandinavischen Vorzeit.-Gunnhild Røthe, Porgerðr Hölgabrúðr - the fylgja of the Háleygjar family.-Michael Schulte, Memory culture in the Viking Ages. The runic evidence of formulaic patterns. - Lennart Elmevik, Yggdrasill. En etymologisk studie.-Henrik Williams, Projektet Originalversionen av Snorre Sturlassons Edda? Studier i Codex Upsaliensis. Ett forskningsprogram.-Sverre Bagge, "Gang leader" eller "The Lord's anointed" i Sverris saga? Svar til Fredrik Ljungqvist og Lars Lönnroth._Heimir Pálsson, Tungviktare i litteraturhistorien. En krönika.

ÅRGÅNG 59 · 2008: Marianne Kalinke, Clári saga. A case of Low German infiltration. - Ármann Jakobsson, En plats i en ny värld. Bilden av riddarsamhället i Morkinskinna.-Margaret Cormack, Catholic saints in Lutheran legend. Post- 
reformation ecclesiastical folklore in Iceland.-Tommy Danielsson, Social eller existentiell oro? Fostbrödradråp i två isländska sagor.-Mathias Strandberg, On the etymology of compounded Old Icelandic Óðinn names with the second component -foðr.-Susanne Haugen, Bautasteinn-fallos? Kring en tolkning av ett fornvästnordiskt ord.-Lasse Mårtensson och Heimir Pálsson, Anmärkningsvärda suspensioner i DG 11 4to (Codex Upsaliensis av Snorra Edda) - spåren av en skriven förlaga? - Stefan Olsson, Harald hos jätten Dovre. Forntida initiationssymbolik i en medeltida tåt.-Bo-A. Wendt, Eddan och texttermerna. Kort terminologiskt genmäle till Henrik Williams.-Michael Schulte, Literacy in the looking glass. Vedic and skaldic verse and the two modes of oral transmission.-Svanhildur Óskarsdóttir, rec. av Skaldic Poetry of the Scandinavian Middle Ages, volume VII: Poetry on Christian Subjects 1-2, ed. Margaret Clunies Ross.-Else Mundal, rec. av Reflections on Old Norse Myths, red. Pernille Hermann, Jens Peter Schjødt och Rasmus Tranum Kristensen._Pernille Hermann, rec. av Learning and Understanding in the Old Norse World. Essays in Honour of Margaret Clunies Ross, ed. Judy Quinn, Kate Heslop och Tarrin Wills. ÅRGÅNG 60 - 2009: Daniel Sävborg, Scripta Islandica 60.-Svanhildur Óskarsdóttir, To the letter. Philology as a core component of Old Norse studies. John McKinnell, Ynglingatal. A minimalist interpretation.-Lars Lönnroth, Old Norse text as performance.-Elena Gurevich, From accusation to narration. The transformation of senna in Íslendinga pættir.-Theodore M. Andersson, The formation of the Kings' sagas._-Helgi Skúli Kjartansson, Law recital according to Old Icelandic law. Written evidence of oral transmission? - Terry Gunnell, Ansgar's conversion of Iceland.-Helen F. Leslie, Border crossings. Landscape and the Other World in the Fornaldarsögur.-Tsukusu Itó, The Gosforth fishingstone and Hymiskviða. An example of inter-communicability between the Old English and Old Norse speakers.

ÅRGÅNG 61 · 2010: Helga Kress, Eine bewusste Antiregel. Die Stimme der Frau in Halldór Laxness Gedichten.-Margrét Eggertsdóttir, Hallgrímur Pétursson and Tormod Torfæus. Their scholarly friendship._Jan Ragnar Hagland, Hefi ek mark á máli mart. Litt om vokabular for særdrag ved folks språk og uttale i gammal-islandsk. - Olof Sundqvist, Om hängningen, de nio nätterna och den dyrköpta kunskapen i Hávamál 138-145. Stefanie Gropper, rec. av Jonatan Pettersson, Fri översättning i det medeltida Västnorden._Jonatan Pettersson, rec. av Alexanders saga, Manuscripta Nordica 2, utg. Andrea de Leeuw van Weenen.Lennart Elmevik, In memoriam. Oskar Bandle, Peter Foote, Björn Hagström. ÅRGÅNG 62 · 2011: Ingvil Brügger Budal, Who is "I"? Translation of riddarasögur as a collective performance.-Finnur Friðriksson, Modern Icelandic: Stable or in a state of flux?-Svante Janson, The Icelandic calendar. Susanne Haugen, anm. av Kormaks saga. Historik och översättning av Ingegerd Fries._Heimir Pálsson, rec. av Úlfar Bragason, Ætt og saga: Um frásagnarfræði Sturlungu eða Íslendinga sögu hinnar miklu._Helgi Skúli Kjartansson, rec. av Rikke Malmros, Vikingernes syn på militær og samfund: Belyst gennem skjaldenes fyrstedigtning._Lasse Mårtensson, rec. av Vår eldste bok. Skrift, 
miljø og biletbruk i den norske homilieboka. Bibliotheca Nordica 3, red. Odd Einar Haugen och Åslaug Ommundsen.-Rune Palm, rec. av. Poetry from the Kings' Sagas 2. From c. 1035-1300 (Skaldic Poetry of the Scandinavian Middle Ages II), ed. Kari Ellen Gade._Úlfar Bragason, rec. av Margaret Clunies Ross, The Cambridge Introduction to the Old Norse-Icelandic Saga.

ÅRGÅNG 63 - 2012: Silvia Hufnagel, Icelandic society and subscribers to Rafn's Fornaldar sögur nordrlanda-Guðrún Kvaran, Nucleus latinitatis og biskop Jón Árnasons orddannelse-Heimir Pálsson, Om källor och källbehandling i Snorris Edda. Tankar kring berättelser om skapelsen-Triin Laidoner, The Flying Noaidi of the North: Sámi Tradition Reflected in the Figure Loki Laufeyjarson in Old Norse Mythology-Lars Wollin, Kringla heimsins-Jordennes krets-Orbis terrarum. The translation of Snorri Sturluson's work in Caroline SwedenPorleifur Hauksson, Implicit ideology and the king's image in Sverris sagaOlof Sundqvist, rec. av Annette Lassen, Odin på kristent pergament. En teksthistorisk studie-Kirsten Wolf, rec. av Rómverja saga, ed. Porbjörg Helgadóttir ÅRGÅNG 64 · 2013: Lennart Elmevik, Sigurd Fries. Minnesord-Daniel Sävborg, Rune Palm. Minnesord-Ulla Börestam, Gun Widmark. Minnesord-Agneta Ney, Bland ormar och drakar. En jämförande studie av Ramsundsristningen och Gökstenen-Judy Quinn, Death and the king: GrottasQngr in its eddic contextBrittany Schorn, Divine Semantics. Terminology for the Human and the Divine in Old Norse Poetry-Kirsten Wolf, Body Language in Medieval Iceland. A Study of Gesticulation in the Sagas and Tales of Icelanders-Terry Gunnell, rec. av Merrill Kaplan, Thou Fearful Guest. Addressing the Past in Four Tales in Flateyjarbók-Bernt $\emptyset$. Thorvaldsen, rec. av Lars Lönnroth, The Academy of Odin. Selected Papers on Old Norse Literature-Vésteinn Ólason, rec. av The Poetic Edda. Vol. III. Mythological Poems II, ed. Ursula Dronke-Lars Wollin, rec. av Sif Rikhardsdottir, Medieval Translations and Cultural Discourse. The Movement of Texts in England, France and Scandinavia-Margaret Clunies Ross, rec. av Snorri Sturluson The Uppsala Edda DG 11 4to, ed. Heimir Pálsson ÅRGÅNG 65 · 2014: Pórdís Edda Jóhannesdóttir \& Veturliði Óskarsson, The Manuscripts of Jómsvíkinga Saga: A Survey-Sirpa Aalto, Jómsvíkinga Saga as a Part of Old Norse Historiography-Leszek P. Stupecki, Comments on Sirpa Aalto's Paper-Alison Finlay, Jómsvíkinga Saga and Genre- Judith Jesch, Jómsvíkinga Sogur and Jómsvíkinga Drápur: Texts, Contexts and IntertextsDaniel Sävborg, Búi the Dragon: Some Intertexts of Jómsvíkinga Saga-Alison Finlay, Comments on Daniel Sävborg's Paper-Jakub Morawiec, Danish Kings and the Foundation of Jómsborg-Władystaw Duczko, Viking-Age Wolin (Wollin) in the Norse Context of the Southern Coast of the Baltic Sea-Michael Lerche Nielsen, Runic Inscriptions Reflecting Linguistic Contacts between WestSlav Lands and Southern Scandinavia-Henrik Williams, Comments on Michael Lerche Nielsen's Paper- Jürgen Udolph, On the Etymology of JómsborgAlexandra Petrulevich, Comments on Jürgen Udolph's Paper-Marie Novotná \& Jiři Starý, Rendering Old Norse Nouns and Names in Translation into WestSlavic Languages 
ÅRGÅNG 66 · 2015: Lise Gjedss $\phi$ Bertelsen, Sigurd Fafnersbane sagnet som fortalt på Ramsundsristningen-Anne-Sofie Gräslund, Kvinnorepresentationen på de senvikingatida runstenarna med utgångspunkt i Sigurdsristningarna-Terry Gunnell, Pantheon? What Pantheon? Concepts of a Family of Gods in PreChristian Scandinavian Religions-Tommy Kuusela, "Den som rider på Freyfaxi ska dö”. Freyfaxis död och rituell nedstörtning av hästar för stup - Lars Lönnroth, Sigurður Nordals brev till Nanna-Jan Alexander van Nahl, The Skilled Narrator. Myth and Scholarship in the Prose Edda-William Sayers, Generational Models for the Friendship of Egill and Arinbjorn (Egils saga Skallagrímssonar)-Olof Sundqvist, The Pre-Christian Cult of Dead Royalty in Old Norse Sources: Medieval Speculations or Ancient Traditions?-Lars Lönnroth, rec. av Minni and Muninn: Memory in Medieval Nordic Culture, red. Pernille Herrmann, Stephen A. Mitchell \& Agnes S. Arnórsdóttir-Olof Sundqvist, rec. av Mikael Males: Mytologi i skaldedikt, skaldedikt i prosa. En synkron analys av mytologiska referenser i medeltida norröna handskrifter-Per-Axel Wiktorsson, rec. av The Power of the Book. Medial Approaches to Medieval Nordic Legal Manuscripts, red. Lena Rohrbach-Kirsten Wolf, rev. of Lasse Mårtensson. Skrivaren och förlagan: Norm och normbrott i Codex Upsaliensis av Snorra Edda

ÅRGÅNG 67 · 2016: Aðalheiður Guðmundsdóttir, Tales of Generations: A comparison between some Icelandic and Geatish narrative motifs-Eldar Heide, The term leizla in Old Norse vision literature - contrasting imported and indigenous genres?-Heimir Pálsson, DG 3 in memoriam-Sveinn Yngvi Egilsson, Jónas Hallgrímssons inre och yttre natur-Úlfar Bragason, Jón Halldórsson of Stóruvellir and his reading circle: Readings in the farming community in Iceland around 1870-Judy Quinn, rev. of Eddukvæði, red. Jónas Kristjánsson \& Vésteinn Ólason-Daniel Sävborg, rec. av Riddarasogur: The Translation of European Court Culture in Medieval Scandinavia, utg. Karl G. Johansson och Else Mundal-Heimir Pálsson, rec. av Pórunn Sigurðardóttir. Heiður og huggun: Erfiljóð, harmljóð og huggunarkvæði á 17. öld-Veturliði Óskarsson, anm. av Jón Ólafsson úr Grunnavík: AEvisögur ypparlegra merkismanna, utg. Guðrún Ása Grímsdóttir

ÅRGÅNG 68 - 2017: Lars Erik Edlund, Ingegerd Fries (1921-2016): Minnesord-Aðalheiður Guðmundsdóttir, Some Heroic Motifs in Icelandic Art-Daniel Sävborg, Blot-Sven: En källundersökning-Declan Taggart, All the Mountains Shake: Seismic and Volcanic Imagery in the Old Norse Literature of Pórr-Elín Bára Magnúsdóttir, Forfatterintrusjon i Grettis saga og paralleller i Sturlas verker-Haukur Porgeirsson \& Teresa Dröfn Njarðvík, The Last Eddas on Vellum-Heimir Pálsson, Reflections on the Creation of Snorri Sturluson's Prose Edda-Magnus Källström, Monumenta lapidum aliquot runicorum: Om runstensbilagan i Verelius' Gothrici \& Rolfi Westrogothiae Regum Historia (1664) Matteo Tarsi, Creating a Norm for the Vernacular: Some Critical Notes on Icelandic and Italian in the Middle Ages-Olof Sundqvist, Blod och blot: Blodets betydelse och funktion vid fornskandinaviska offerriter-Sveinn Yngvi Egilsson, Kan man skriva pastoral poesi så nära Nordpolen? Arkadiska skildringar i is- 
ländska dikter från artonhundratalet-Tommy Kuusela, "Pá mælti Míms hǫfuð": Jätten Mimer som kunskapsförmedlare i fornnordisk tradition-Lars Lönnroth, rec. av A Handbook to Eddic Poetry: Myths and Legends of Early Scandinavia, red. Carolyne Larrington, Judy Quinn \& Brittany Schorn-Lars-Erik Edlund, rec. av Islänningasagorna. Samtliga släktsagor och fyrtionio tåtar. Red. Kristinn Jóhannesson, Gunnar D. Hansson \& Karl G. Johansson-Aðalheiður Guðmundsdóttir, rev. of Agneta Ney. Bland ormar och drakar: Hjältemyt och manligt ideal $i$ berättartraditioner om Sigurd Fafnesbane

ÅRGÅNG 69 - 2018: Klas af Edholm, Att rista blodörn: Blodörnsriten sedd som offer och ritualiserad våldspraktik i samband med maktskiften i fornnordisk tradition-Jan Ragnar Hagland, Litt om kvinnekroppen i norrøn leksikografisk samanheng_Luke John Murphy, Paganism at Home: Pre-Christian Private Praxis and Household Religion in the Iron-Age North-Ludger Zeevaert, Eine deutsche Zusammenfassung von Njáls saga im Manuskript Rostock Mss. philol. 78/2Heimir Pálsson, Nordens latin-Sigurður Gylfi Magnússon, What Takes Place, When Nothing Happens? The importance of late modern manuscript culturePernille Hermann, rec. av Jón Karl Helgason. Echoes of Valhalla. The Afterlife of the Eddas and Sagas-Mikael Males, rec. av Skaldic Poetry of the Scandinavian Middle Ages, 3: Poetry from Treatises on Poetics, utg. Kari Ellen Gade med Edith Marold-Alexandra Petrulevich, rec. av Studies in the transmission and reception of Old Norse literature. The Hyperborean muse in European culture, red. Judy Quinn \& Adele Cipolla-Olof Sundqvist, rec. av Declan Taggart. How Thor Lost his Thunder. The Changing Faces of an Old Norse God-Vésteinn Ólason, rec. av Poetry in fornaldarsögur. Part 1 and 2, utg. Margaret Clunies Ross

ÅRGÅNG 70 - 2019: Ada Kan, Lars Lönnroth och Agneta Ney, Elena Gurevich (1957-2018). Minnesord-Anders Hultgård, Om Vafprúðnismál-Andras Mortensen, Færeyinga saga som historisk kilde: En vurdering af sagaens ophavssituation og politiske miljø-Guðmundur Ólafsson og Lise Gjedss $\phi$ Bertelsen, Det henrettede par i dobbeltgravhøjene i Kópavogur syd for Reykjavík i ÍslandHubert Seelow, Sjö plánetur i ljóðmaelum: Ein isländisches Gedicht über die Planetenkinder. Mit einem Exkurs: Kritische Anmerkungen zur Laienastrologie und Laienphilologie-Matteo Tarsi, Instances of loanword/native word textual variation in the manuscript transmission of Egils saga Skallagrimssonar and Gísla saga Súrssonar-Marianne Kalinke, rev. of Natalie M. Van Deusen. The Saga of the Sister Saints. The Legend of Martha and Mary Magdalen in Old Norse-Icelandic Translation-Olof Sundqvist, rec. av Anders Hultgård. Midgård brinner. Ragnarök i religionshistorisk belysning

ÅRGÅNG 71 - 2020: Henrik Williams, Jan Axelson in memoriam-Brynja Porgeirsdóttir, The Language of Feeling in Njáls saga and Egils saga: Construction of an Emotional Lexis-Katarzyna Anna Kapitan, Medieval Poetry in Post-medieval Manuscripts: New Perspectives on the Transmission History of Griplur-Lise Gjedss $\phi$ Bertelsen, Om Taustaven fra Pingvellir, Island: Skálholtbispen Ísleifur Gissurarsons hyrdestav?-Már Jónsson, An Icelandic Noctuary of 1794-Ebbe Nyborg and Jette Arneborg, Christian Medieval Art in Norse Green- 
land: Crosses and Crucifixes and their European Antecedents-Olof Sundqvist, Rec. av Triin Laidoner. Ancestor Worship and the Elite in Late Iron Age Scandinavia. A Grave Matter

ÅRGÅNG 72 - 2021: Felix Lummer, Of Magical Beings and Where to Find Them: On the Concept of álfar in the translated riddarasogur-Frog, Preserving Blunders in Eddic Poems: Formula Variation in Numbered Inventories of Vafprúðnismál and Grímnismál-Lasse Mårtensson, The Change menninir > mennurnir, mennirnir in Icelandic-Martin Ringmar, Läsning för folket? Gunnlaugs saga ormstungu i skandinaviska nyöversättningar: Hur? För vem? Varför?Mikael Males, Kan fornisländskans rúnar betyda 'bokstäver'?-Lasse Mårtensson, Rec. av Karl G. Johansson och Elise Kleivane (red.). Speculum septentrionale . Konungs skuggsjá and the European Encyclopedia of the Middle Ages 
